\title{
NATIONAL RENEWABLE ENERGY LABORATORY \\ ENVIRONMENTAL PERFORMANCE REPORT FOR 2009 \\ (Annual Site Environmental Report per DOE Orders 231.1 and 5400.1)
}

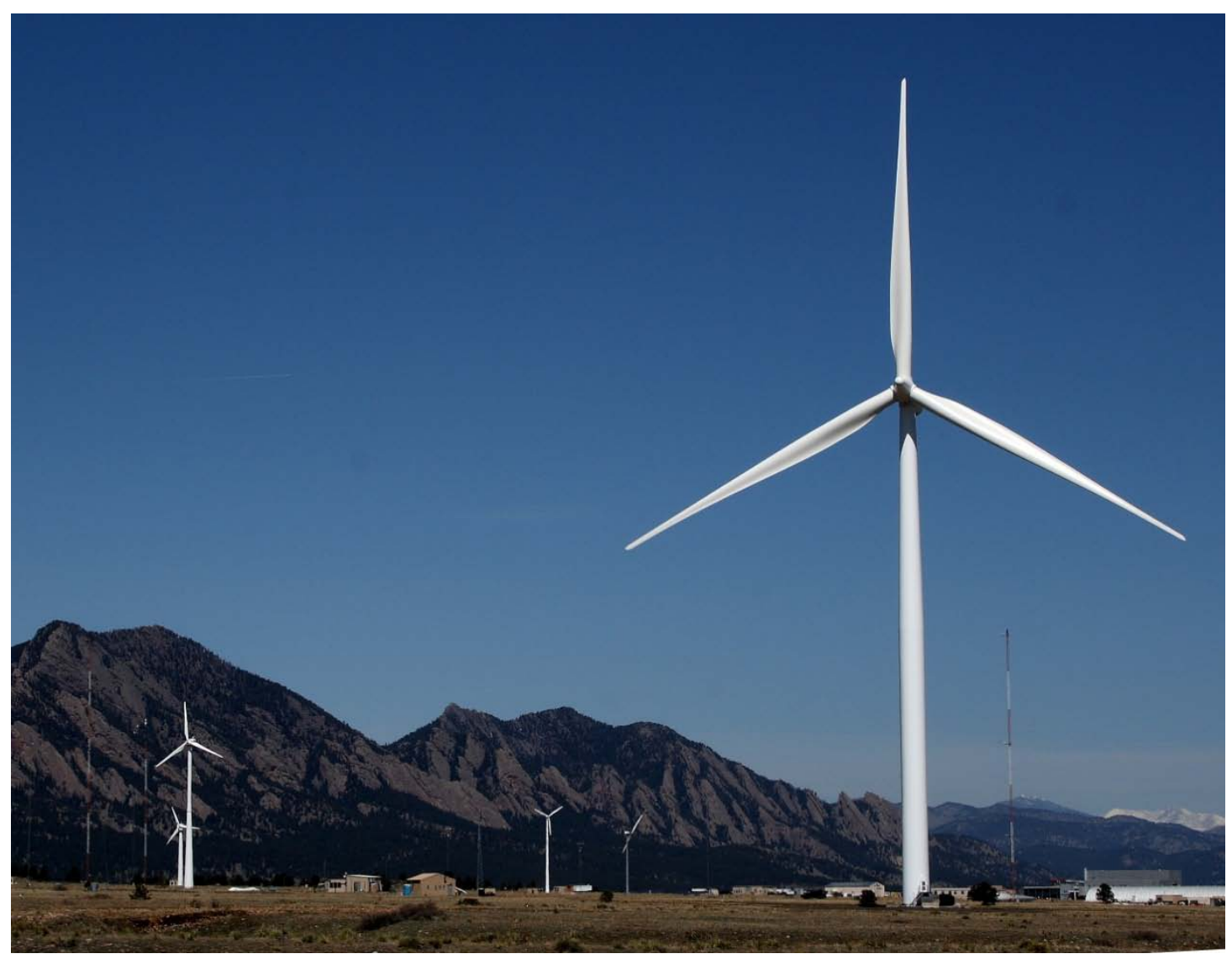

Prepared by:

Environment, Health, and Safety Office

National Renewable Energy Laboratory

NREL is a national laboratory of the

U.S. Department of Energy and is

Operated by the Alliance for Sustainable Energy, LLC 


\section{Cover Photo contributed by Bob Fiehweg, 2009 - Siemens Wind Turbine at the National Wind Technology Center.}

\section{NOTICE}

This report was prepared as an account of work sponsored by an agency of the United States government. Neither the United States government nor any agency thereof, nor any of their employees, makes any warranty, express or implied, or assumes any legal liability or responsibility for the accuracy, completeness, or usefulness of any information, apparatus, product, or process disclosed, or represents that its use would not infringe privately owned rights. Reference herein to any specific commercial product, process, or service by trade name, trademark, manufacturer, or otherwise does not necessarily constitute or imply its endorsement, recommendation, or favoring by the United States government or any agency thereof. The views and opinions of authors expressed herein do not necessarily state or reflect those of the United States government or any agency thereof.

Available electronically at http://www.osti.gov/bridge

Available for a processing fee to U.S. Department of Energy and its contractors, in paper, from:

U.S. Department of Energy

Office of Scientific and Technical Information

P.O. Box 62

Oak Ridge, TN 37831-0062

phone: 865.576 .8401

fax: 865.576 .5728

email: mailto:reports@adonis.osti.gov

Available for sale to the public, in paper, from:

U.S. Department of Commerce

National Technical Information Service

5285 Port Royal Road

Springfield, VA 22161

phone: 800.553.6847

fax: 703.605.6900

email: orders@ntis.fedworld.gov

online ordering: http://www.ntis.gov/ordering.htm 


\section{List of Acronyms}

\begin{tabular}{|c|c|}
\hline AEO & Annual Energy Outlook \\
\hline AFUF & Alternative Fuels User Facility \\
\hline APEN & Air Pollution Emission Notice \\
\hline AST & Aboveground storage tank \\
\hline bgs & Below ground surface \\
\hline BMP & Best management practice \\
\hline BTU & British thermal unit \\
\hline CDPHE & Colorado Department of Public Health and Environment \\
\hline CEQ & Council of Environmental Quality \\
\hline CFR & Code of Federal Regulations \\
\hline CGP & Construction General Permit \\
\hline CMS & Chemical Management System \\
\hline CSP & Concentrating solar power \\
\hline CY & Calendar Year \\
\hline DBP & Disinfection byproduct \\
\hline DFD & Denver Fire Department \\
\hline DOE & U.S. Department of Energy \\
\hline DOE-GO & Department of Energy Golden Field Office \\
\hline DSOC & District Shops and Operation Center \\
\hline DWOP & Denver West Office Park \\
\hline EA & Environmental Assessment \\
\hline EHS & Environment, Health, and Safety Office \\
\hline EIA & Energy Information Agency \\
\hline EISA & Energy Independence and Security Act \\
\hline ELP & Environmental Leadership Program \\
\hline EMS & Environmental management system \\
\hline EO & Executive Order \\
\hline EPA & U.S. Environmental Protection Agency \\
\hline EPCRA & Emergency Reporting and Community Right-to-Know Act \\
\hline ES\&H & Environment, Safety, and Health \\
\hline ESH\&Q & Environmental Safety, Health, and Quality \\
\hline FEC & Federal Electronics Challenge \\
\hline FTLB & Field Test Laboratory Building \\
\hline FY & Fiscal Year \\
\hline GHG & Greenhouse gas \\
\hline gsf & Gross square foot \\
\hline HAA5 & Haloacetic acids \\
\hline HABS & Historic American Buildings Survey \\
\hline HAER & Historic American Engineering Record \\
\hline HMIS & Hazardous Materials Information System \\
\hline HSS & U.S. Department of Energy Office of Health, Safety, and Security \\
\hline IPM & Integrated pest management \\
\hline IRCA & International Register of Certificated Auditors \\
\hline ISM & Integrated safety management \\
\hline
\end{tabular}




$\begin{array}{ll}\text { ISMS } & \text { Integrated Safety Management System } \\ \text { ISO } & \text { International Organization for Standardization } \\ \text { IUF } & \text { Industrial User Facility } \\ \text { JSF } & \text { Joyce Street Facility } \\ \text { LDRD } & \text { Laboratory directed research and development } \\ \text { LEED } & \text { Leadership in Energy and Environmental Design } \\ \text { LEPC } & \text { Local Emergency Planning Committee } \\ \text { MCL } & \text { Maximum contaminant levels } \\ \text { MRI } & \text { Midwest Research Institute } \\ \text { MtC/yr } & \text { Million metrics tons of carbon per year } \\ \text { NEPA } & \text { National Environmental Policy Act } \\ \text { NESHAP } & \text { National Emissions Standards for Hazardous Air Pollutant } \\ \text { NOI } & \text { Notice of intent } \\ \text { NPDES } & \text { National Pollutant Discharge Elimination System } \\ \text { NREL } & \text { National Renewable Energy Laboratory } \\ \text { NWTC } & \text { National Wind Technology Center } \\ \text { ODS } & \text { Ozone-depleting substances } \\ \text { PDU } & \text { Process Demonstration Unit } \\ \text { ppm } & \text { Parts per million } \\ \text { PV } & \text { Photovoltaics } \\ \text { PWSID } & \text { Public Water Supply Identification Number } \\ \text { RAA } & \text { Running annual average } \\ \text { RCRA } & \text { Resource Conservation and Recovery Act } \\ \text { RFHP } & \text { Renewable Fuels Heat Plant } \\ \text { ReFUEL } & \text { Renewable Fuels and Lubricants Research Laboratory } \\ \text { RQ } & \text { Reportable quantity } \\ \text { RSF } & \text { Research Support Facilities } \\ \text { RTD } & \text { Regional Transportation District } \\ \text { S\&TF } & \text { Science and Technology Facility } \\ \text { SARA } & \text { Superfund Amendments and Reauthorization Act } \\ \text { SERC } & \text { State Emergency Response Commission } \\ \text { SERF } & \text { Solar Energy Research Facility } \\ \text { SERI } & \text { Solar Energy Research Facility } \\ \text { SHPO } & \text { State Historic Preservation Officer } \\ \text { SIC } & \text { Standard industrial classification } \\ \text { SOP } & \text { Safe operating procedure } \\ \text { SRRL } & \text { Solar Radiation Research Laboratory } \\ \text { STM } & \text { South Table Mountain } \\ \text { TCPDU } & \text { Thermochemical Process Demonstration Unit } \\ \text { TPQ } & \text { Threshold planning quantity } \\ \text { TTHM } & \text { Trihalomethane } \\ \text { USACE } & \text { U.S. Army Corps of Engineers } \\ \text { USDA } & \text { U.S. Department of Agriculture } \\ \text { WHF } & \text { Waste Handling Facility } \\ & \end{array}$




\section{Table of Contents}

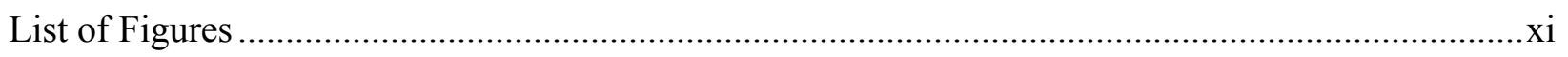

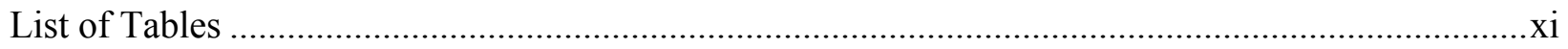

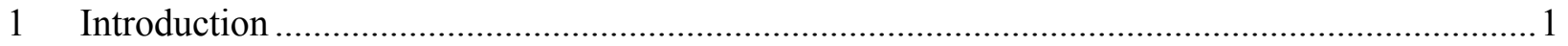

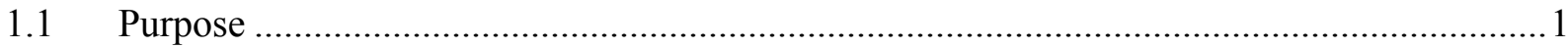

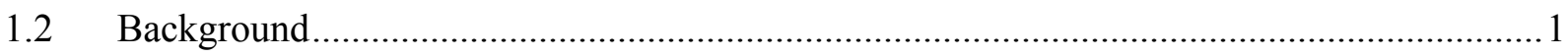

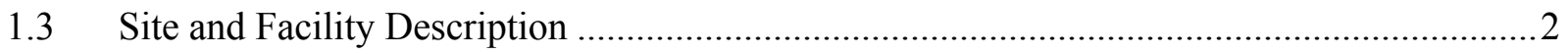

1.3.1 South Table Mountain Site ……………………………………………………….....11

1.3.1.1 Geology, Soils, and Hydrogeology …………………......................................... 11

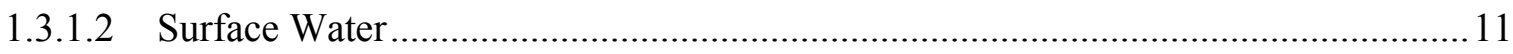

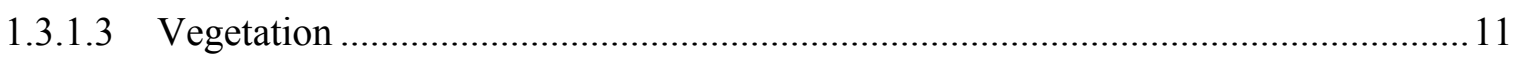

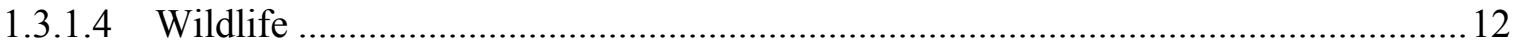

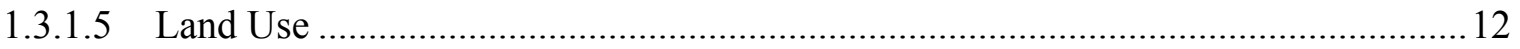

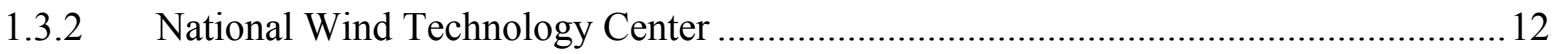

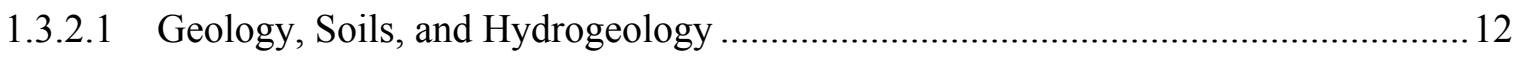

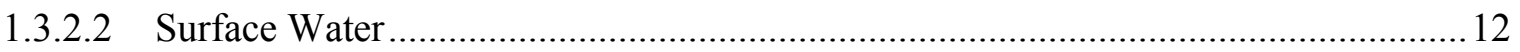

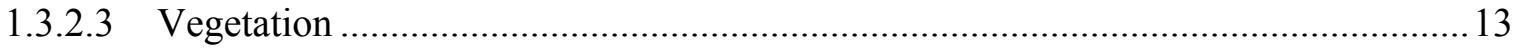

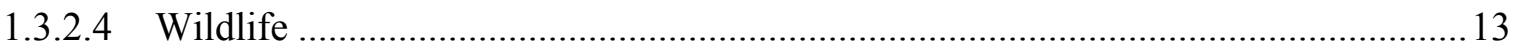

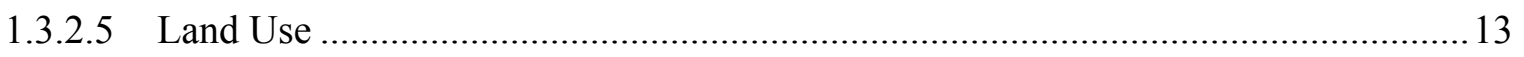

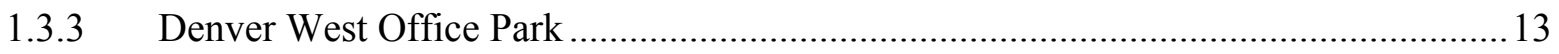

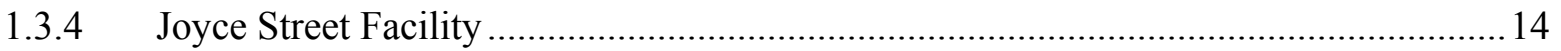

1.3.5 Renewable Fuels and Lubricants Research Laboratory ………………….................. 14

1.4 Site Environmental Conditions/Features ....................................................................... 14

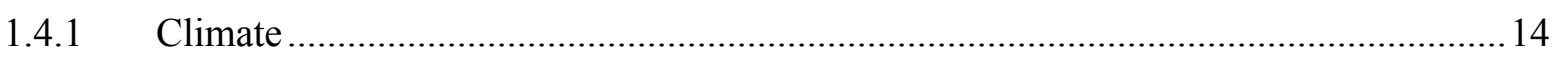

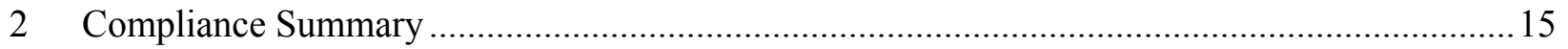

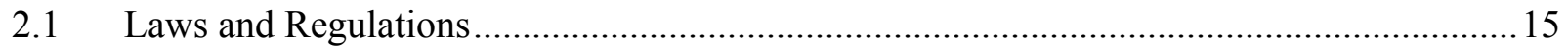

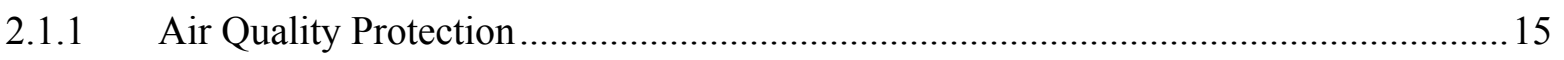

2.1.2 Drinking Water Quality Protection ……………………………………………..... 15

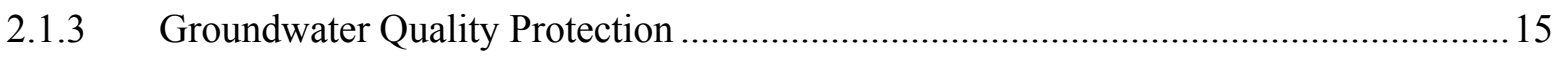

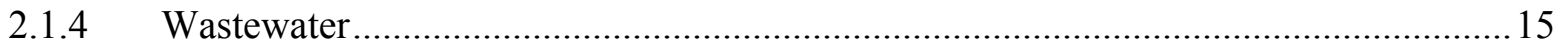

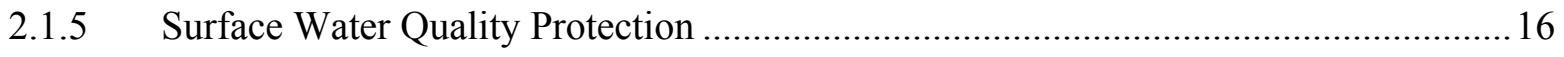




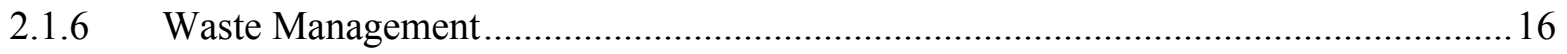

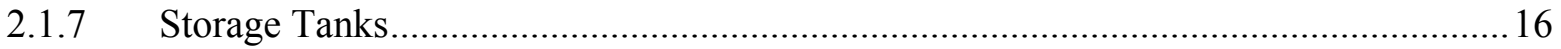

2.1.8 Threatened and Endangered Species/Species of Concern ...........................................16

2.1.9 EPCRA Compliance and Prevention of Toxic Releases................................................ 17

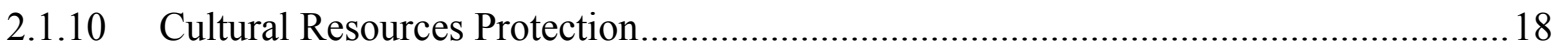

2.2 DOE Order 450.1A, Environmental Protection Program....................................................... 18

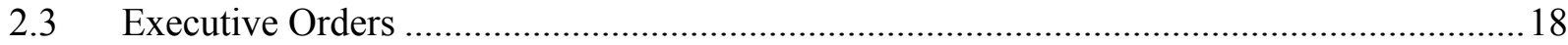

2.3.1 Executive Order 13514, Federal Leadership in Environmental, Energy, and Economic

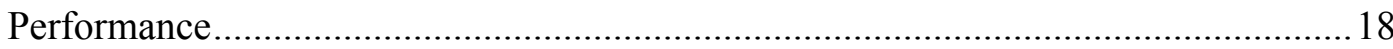

2.3.2 Executive Order 13423, Strengthening Federal Environmental, Energy, and

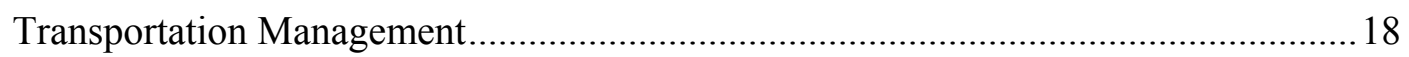

2.3.3 Executive Order 11988, Floodplains Management.................................................... 19

2.3.4 Executive Order 11990, Wetlands Protection............................................................. 19

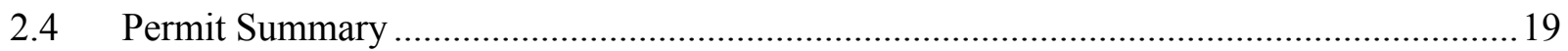

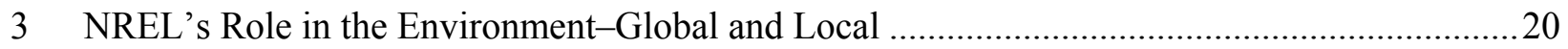

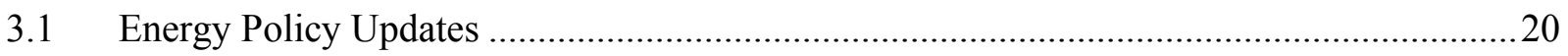

3.2 NREL Research Helping Meet Legislative Goals ..............................................................21

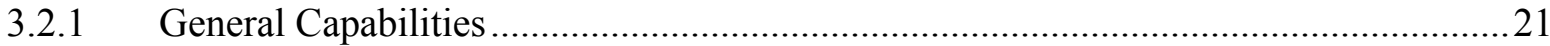

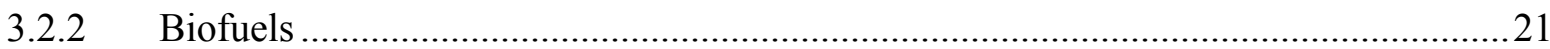

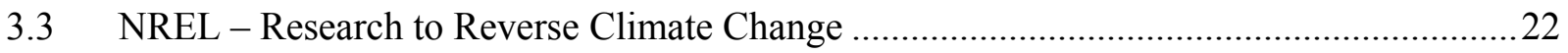

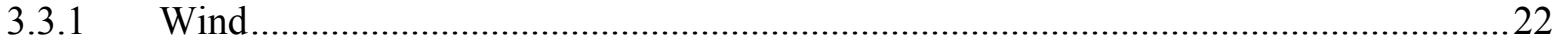

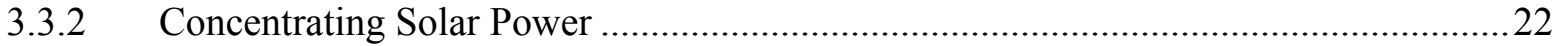

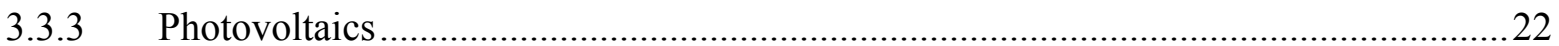

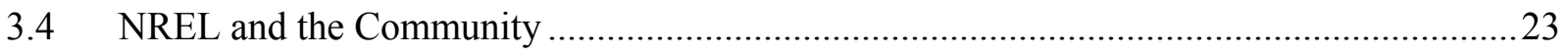

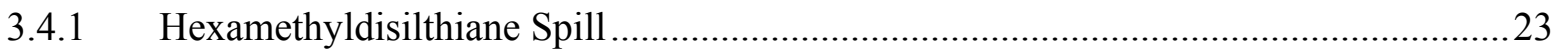

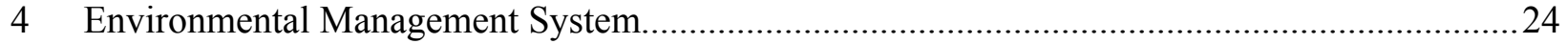

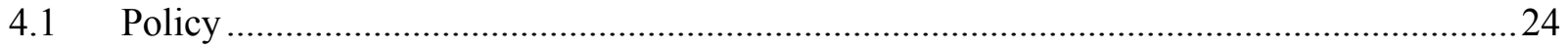

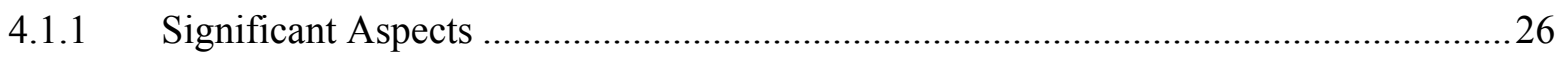

4.1.2 EMS Effectiveness - Benefits to the Environment and NREL …………………........26

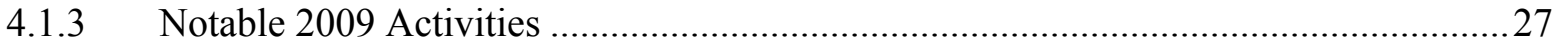

4.1.3.1 Federal Electronics Challenge ............................................................................2

4.1.3.2 External EMS Audit......................................................................................2 
4.1.3.3 Colorado Environmental Leadership Program..................................................28

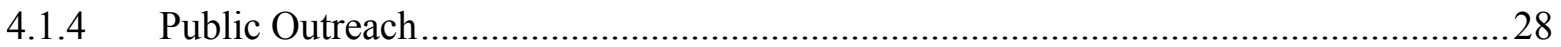

4.2 Performance Indicators and Progress ............................................................................28

4.2.1 2009 Environmental Objectives and Progress toward Goals ....................................29

4.2.2 State of Colorado ELP Commitments $(2007-2010)$.................................................29

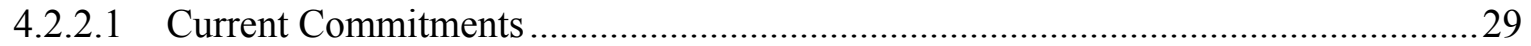

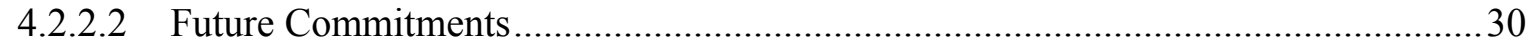

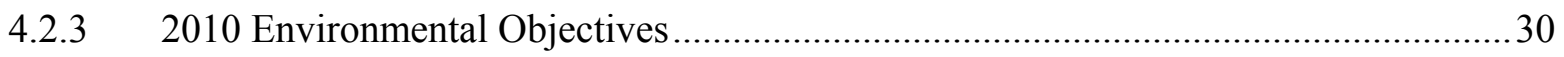

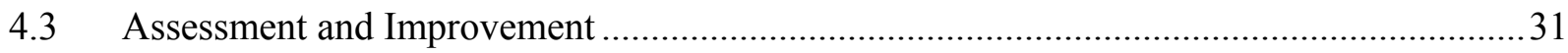

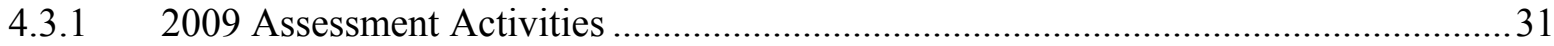

4.4 Sustainability and the Environmental Management System ..........................................32

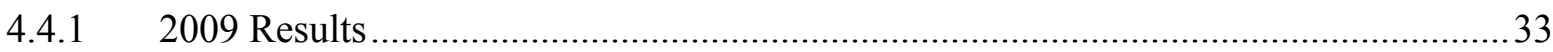

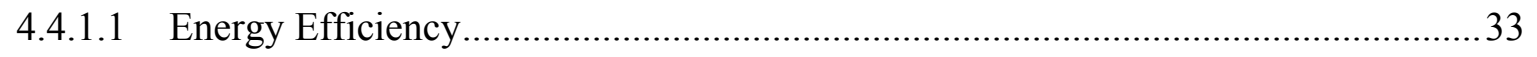

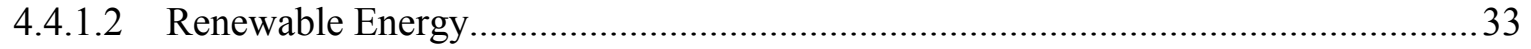

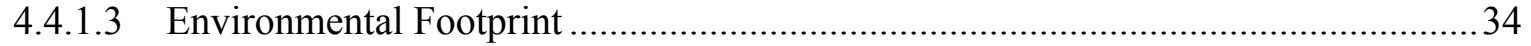

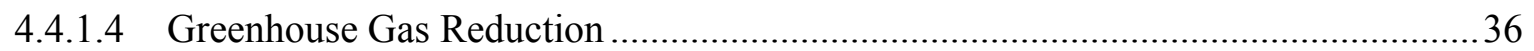

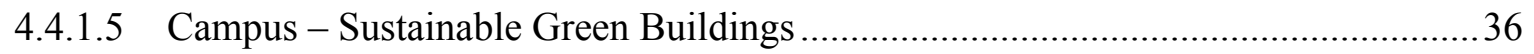

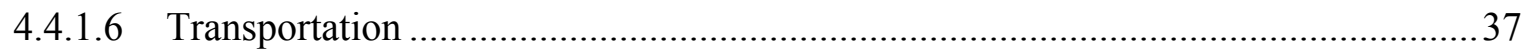

4.4.1.7 Alternative-Fuel Vehicles and Bio-Based Fuels ................................................... 37

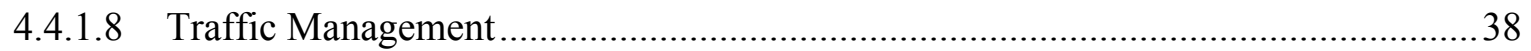

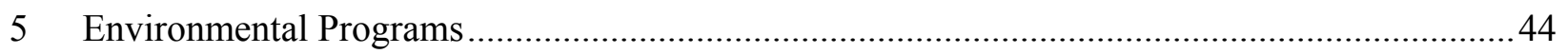

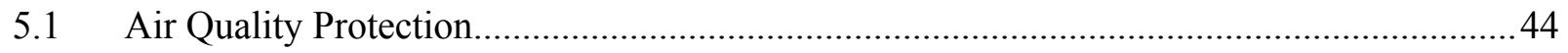

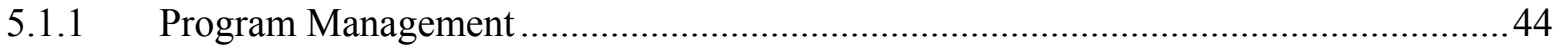

5.1.1.1 Criteria, Hazardous, and Non-Criteria Pollutants ................................................ 44

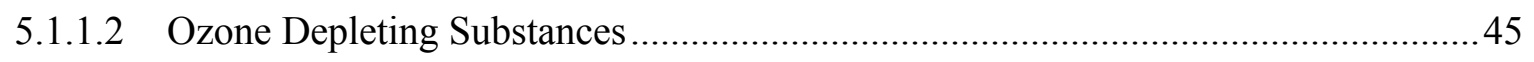

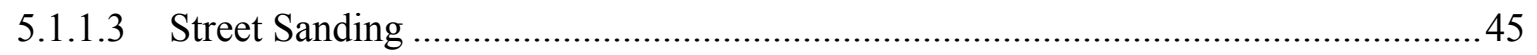

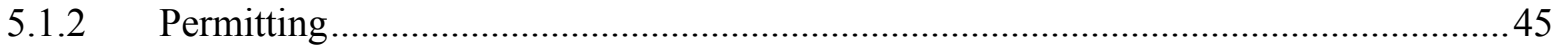

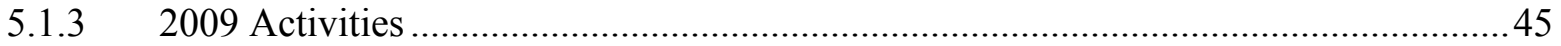

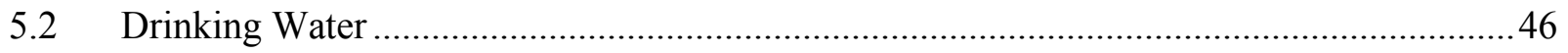

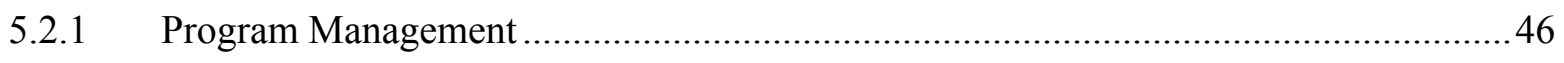

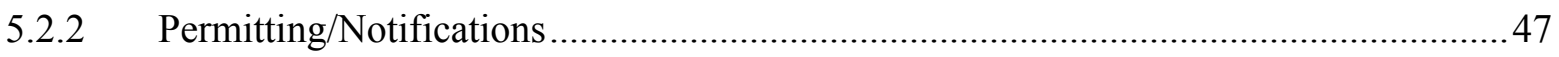

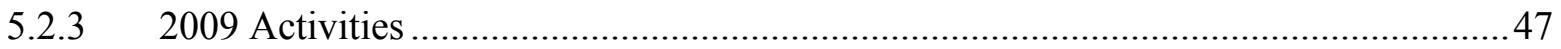




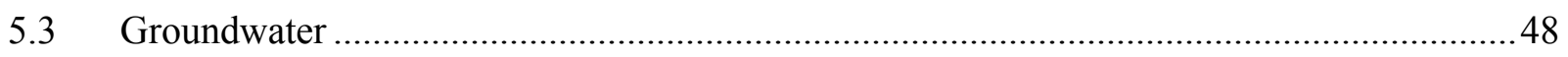

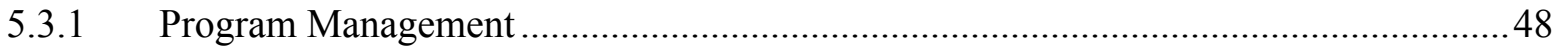

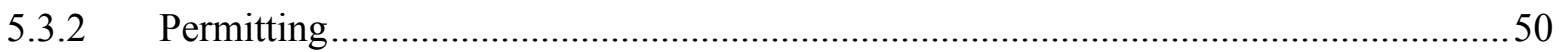

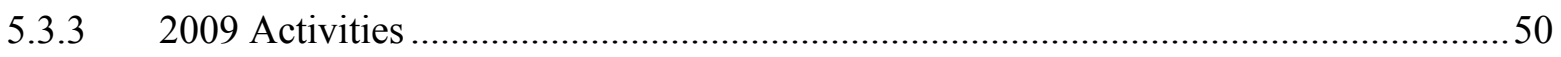

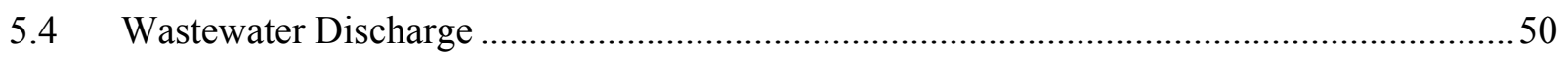

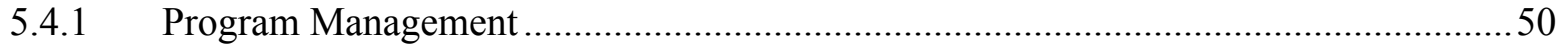

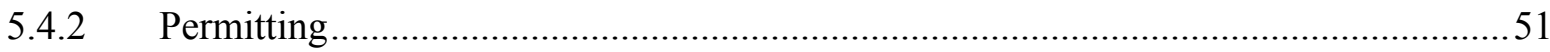

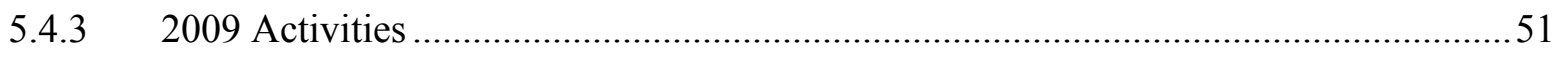

5.5 Surface Water Protection (Stormwater and Erosion Control) .........................................51

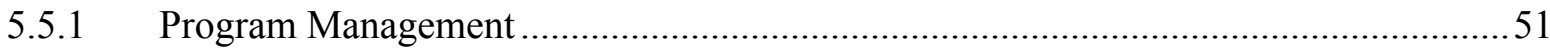

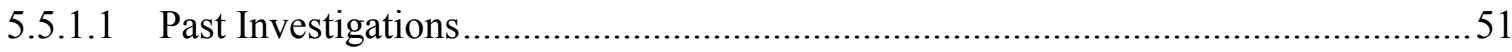

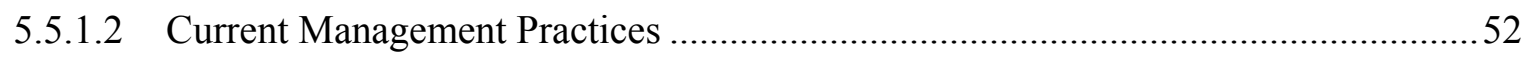

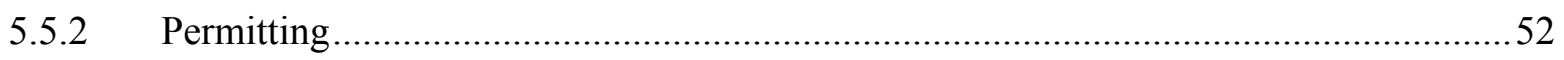

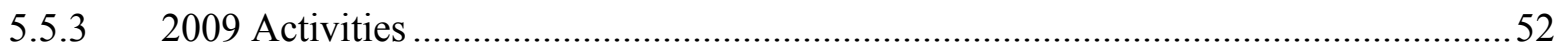

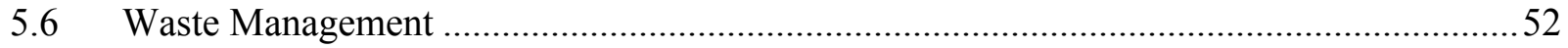

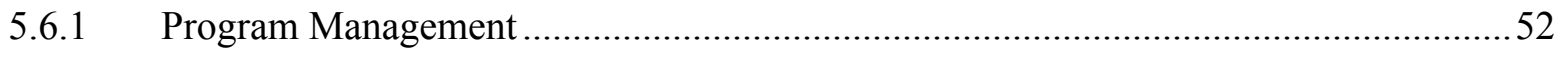

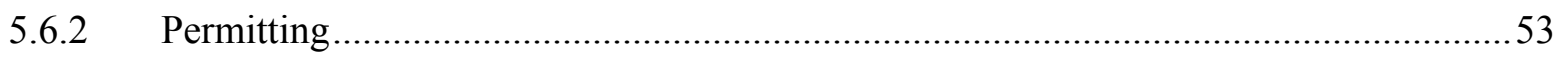

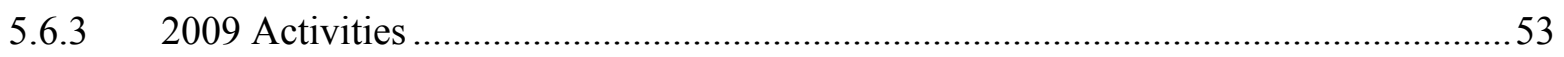

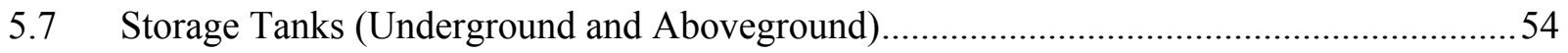

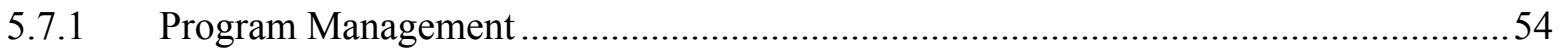

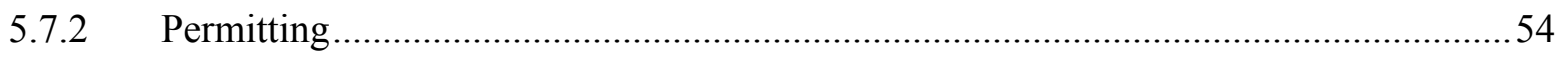

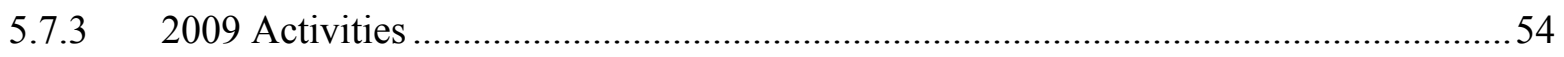

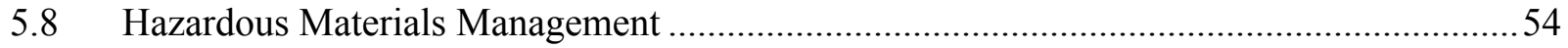

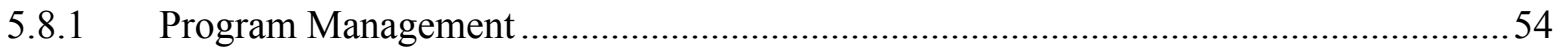

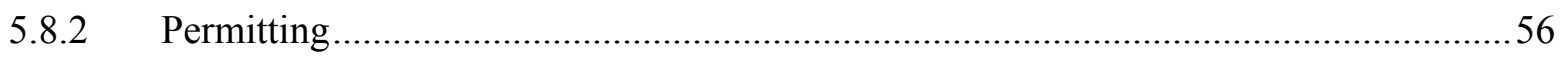

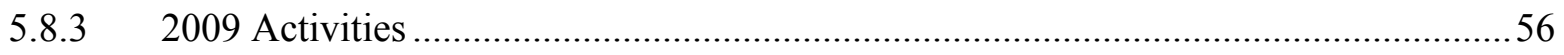

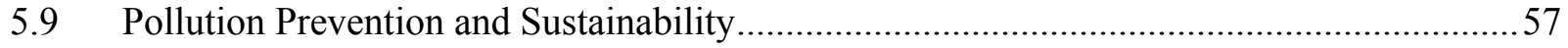

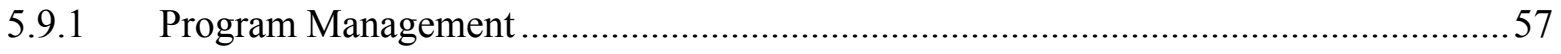

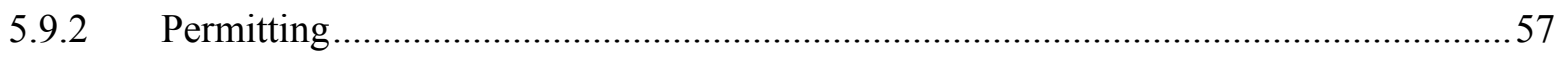

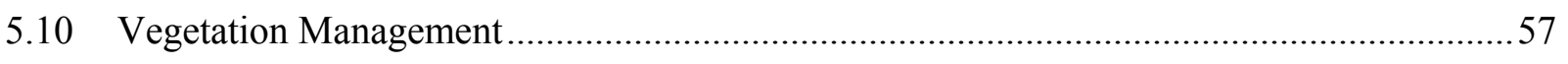

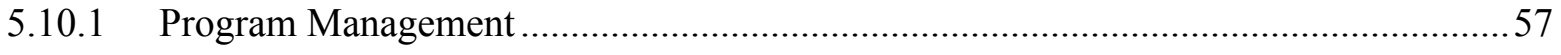

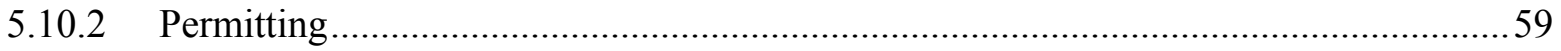




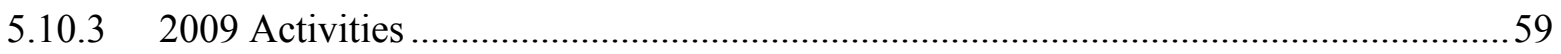

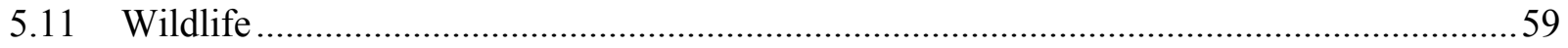

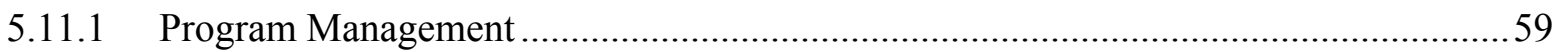

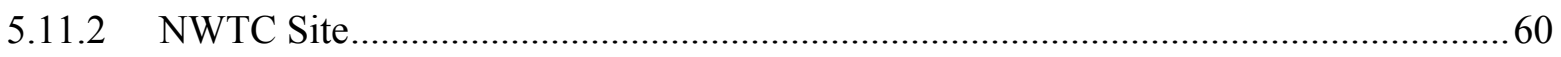

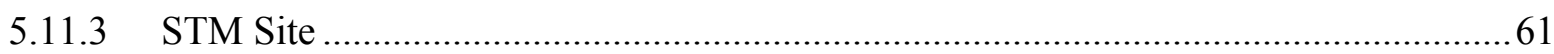

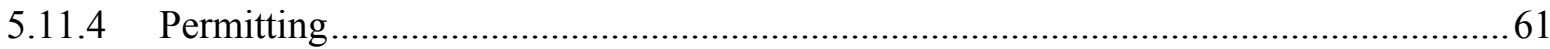

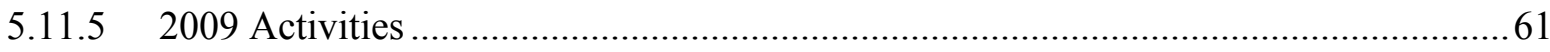

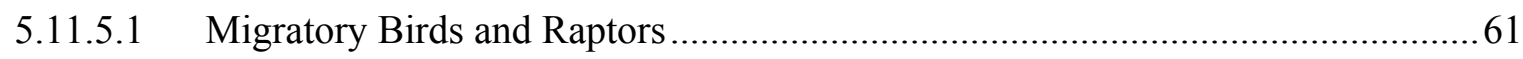

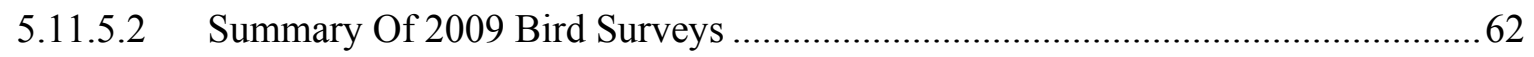

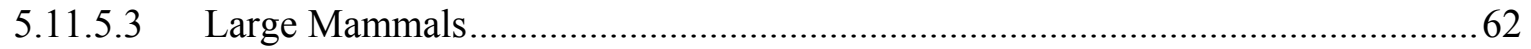

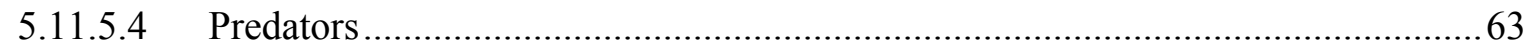

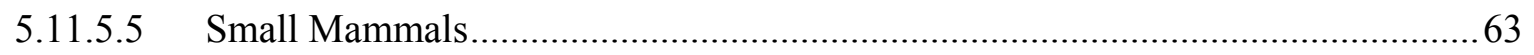

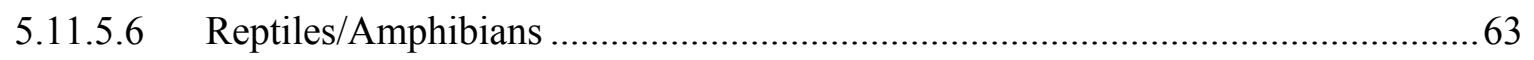

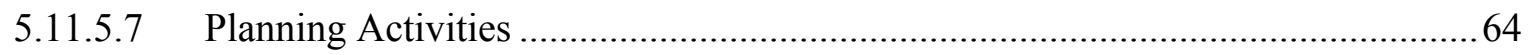

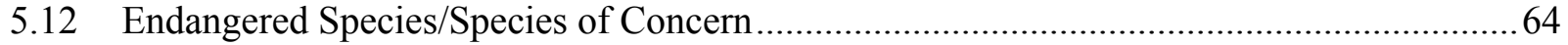

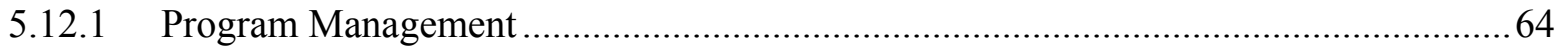

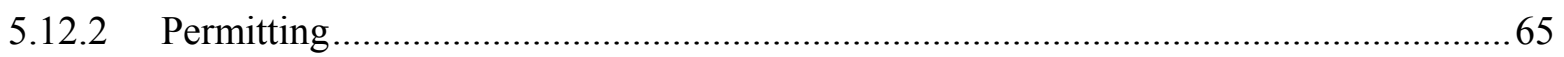

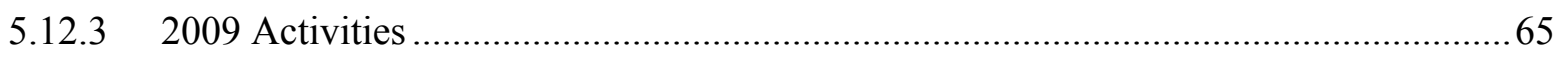

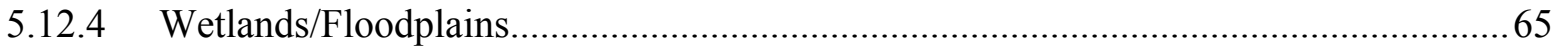

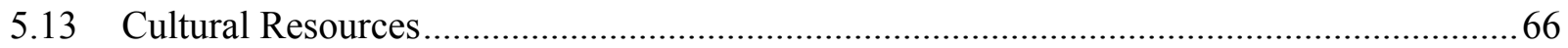

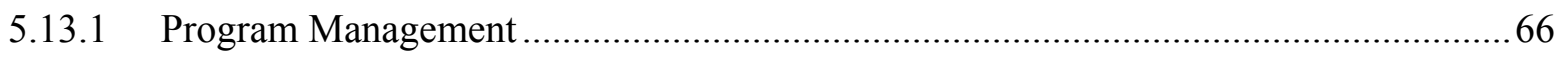

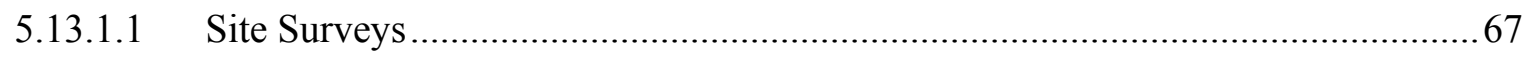

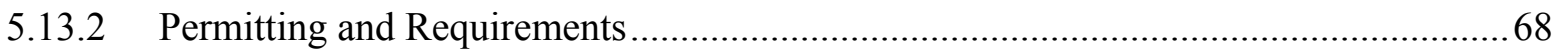

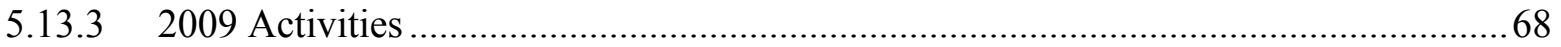

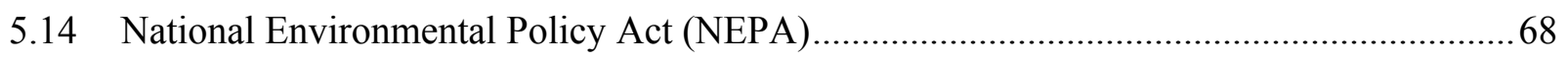

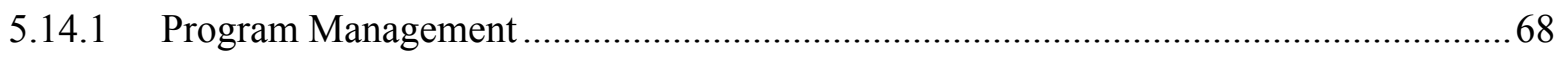

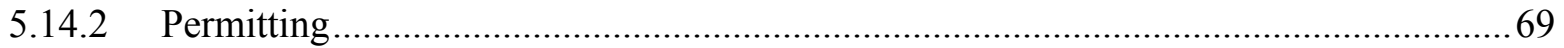

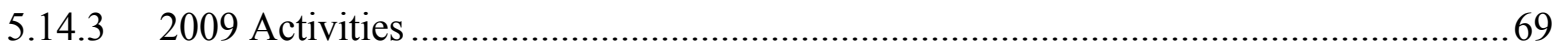

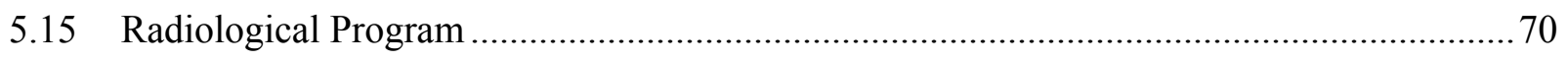

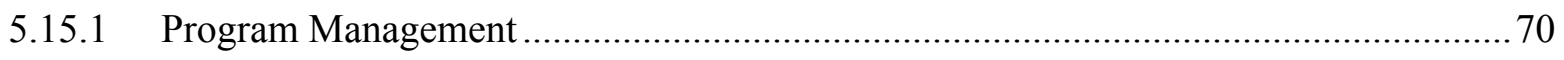

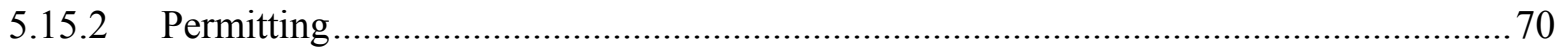

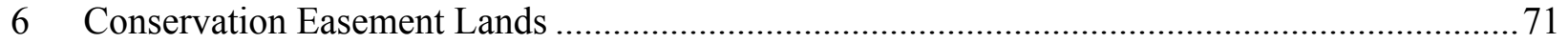




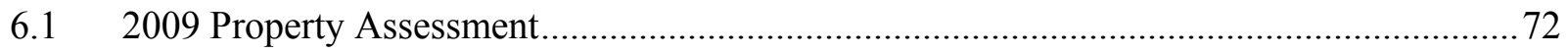

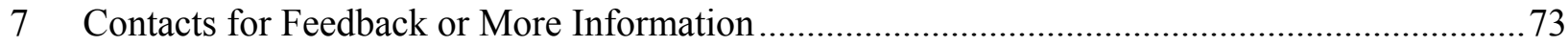

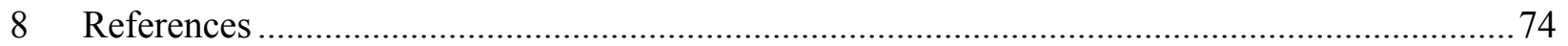

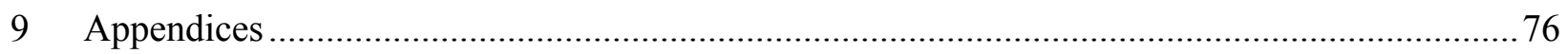

9.1 Appendix A: Summary of NREL Environmental Permits, Registrations, Notifications .....77

9.2 Appendix B: Wildlife Species Observed at NREL's STM Site ......................................86 


\section{List of Figures}

Figure 1. Regional map showing NREL locations in Jefferson County, CO ............................ 4

Figure 2. ReFUEL Facility location map, located in Denver County, CO ................................. 5

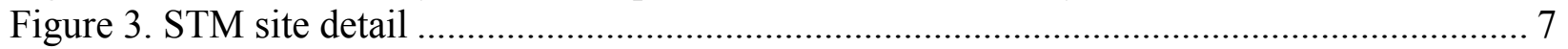

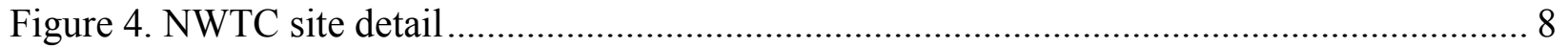

Figure 5. Research Support Facility.............................................................................. 9

Figure 6. South Table Mountain Mesa Top ........................................................................ 9

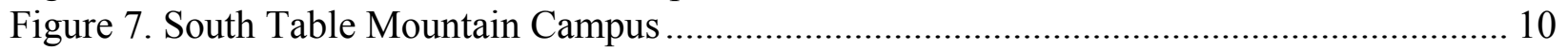

Figure 8. Denver West Office Park.................................................................................... 10

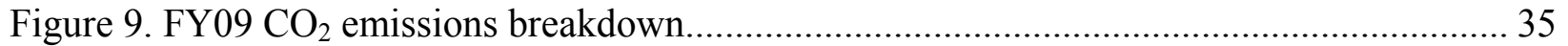

Figure 10. Climate Leaders Program, NREL total GHG emissions ........................................ 35

Figure 11. Number of employees telecommuting and AWS ............................................ 39

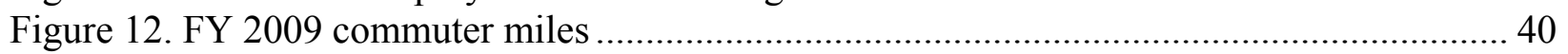

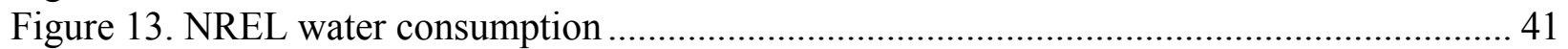

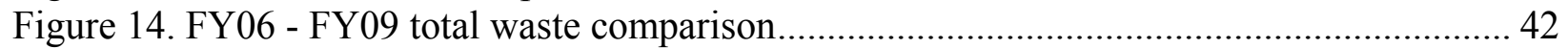

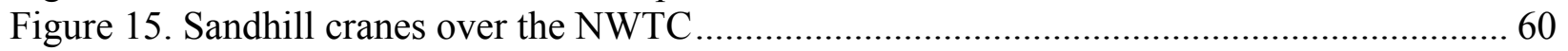

Figure 16. Western kingbirds nesting in an old shoe in the SERF parking lot......................... 61

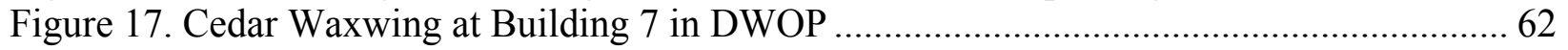

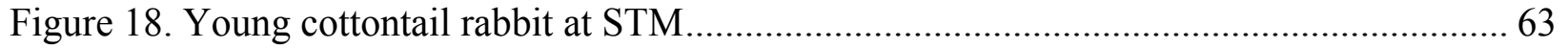

Figure 19. South Table Mountain conservation easement area ........................................... 71

\section{List of Tables}

Table 1. Status of EPCRA Reporting .................................................................................... 17

Table 2. On-site Renewable Energy Projects ....................................................................... 34

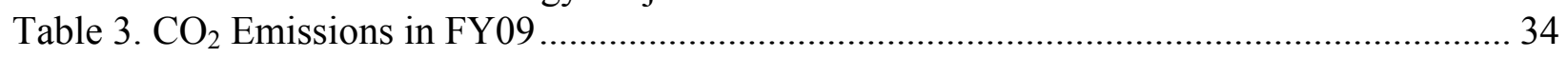

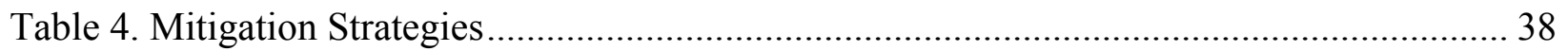

Table 5. Other Recycled Items (By Pounds) ........................................................................... 43

Table 6. Summary of NREL Environmental Permits, Registrations, Notifications .................... 77

Table 7. Wildlife Species Observed at NREL's STM Site ................................................... 86 


\section{Introduction}

The National Renewable Energy Laboratory (NREL) is the nation's premier laboratory for renewable energy research and development and a leading laboratory for energy efficiency research, with programs in wind energy, solar energy, plant and waste-derived fuels and chemicals, energy efficiency in buildings, geothermal energy, advanced vehicle design, hydrogen infrastructure, and fuel cells. Established in 1974, NREL began operating in 1977 as the Solar Energy Research Institute (SERI). It was designated a U.S. Department of Energy (DOE) national laboratory in September 1991 as the National Renewable Energy Laboratory. NREL conducts research primarily for DOE's Office of Energy Efficiency and Renewable Energy. In October 2008, operations at NREL were transferred to the Alliance for Sustainable Energy, LLC, a partnership between the Midwest Research Institute (MRI) and the Battelle Memorial Institute. The new operating contract has a 5-year duration and is overseen by the Department of Energy's Golden Office (DOE-GO).

\subsection{Purpose}

This report presents a summary of NREL's environmental protection programs and activities for 2009. It is organized according to the different environmental media (e.g., air, waste, ground water, etc.), and includes a brief summary of how the program is managed in that area, any permitting or notification efforts that have been completed during the reporting period or are ongoing, and activities that have occurred during the reporting period in that environmental area. A description of the environmental condition and features of NREL's sites is also included to provide a basis for the program overview.

This report is organized to present many of the elements of the Global Reporting Initiative Sustainability Reporting Guidelines. It also incorporates DOE's most recent guidelines for the Annual Site Environmental Report, as required by DOE Orders 231.1A and 5400.5.

\subsection{Background}

NREL's mission and strategy are focused on advancing the U.S. Department of Energy's and our nation's energy goals. This focus is captured in the mission statement:

NREL develops renewable energy and energy efficiency technologies and practices, advances related science and engineering, and transfers knowledge and innovations to address the nation's energy and environmental goals.

NREL fulfills its mission through technology portfolios; a brief description of each major technology area follows.

Basic Science: Fundamental research is conducted in the sciences that underlie NREL's renewable energy and energy efficient technologies.

Bioenergy: NREL currently has major programs in biomass-derived fuels (biofuels) and biomassderived electricity (biopower), and projects in biomass-derived chemicals and materials.

Building Energy: NREL increases the use of energy efficiency technologies and expands the use of renewable energy technologies in the building sector by working to develop new, cost-effective, environmentally acceptable building equipment and envelope systems. 
Computational Sciences: This area includes basic and applied research using high-performance computing and applied mathematics.

Distributed Power: Distributed power is modular electric generation or storage located near the point of use. NREL participates in the development of technologies, market structures, and policies that affect the incorporation of renewables and energy efficiency technologies in distributed power systems, maximizing the utilization of renewable energy and energy efficiency products. As a part of this initiative, NREL is involved in the development, design, and facilitation of the application of renewable and renewable/fossil hybrid distributed power systems in grid-connected applications.

Electricity Technologies: These technologies include renewable energy, hydrogen, and superconductivity technologies, as well as utility resources.

Energy Analysis: Research at NREL includes energy analysis for various programs and initiatives.

Hydrogen: NREL serves as a leader in renewable hydrogen production technologies. NREL also leads in the development of codes, standards, and advanced storage and sensors. Basic and applied research and material development using biology, physics, and chemistry enable and support the development of hydrogen production, storage, and end-use systems.

Measurements and Testing: NREL labs and facilities allow state-of-the-art testing on photovoltaic cells, building technologies, and wind turbines.

Photovoltaics: Photovoltaics (PV) enable the direct conversion of sunlight to electricity using solidstate materials. The National Center for Photovoltaics develops and deploys PV technology for the generation of electric power.

Renewable Energy Resources: Researchers develop resource information for solar, wind, biomass, and geothermal energy applications.

Renewable Thermal Technologies: These technologies - including concentrating solar power (CSP), solar water heating, and geothermal heat and power-generate power from heat or utilize heat from renewable resources.

Transportation: NREL works with industry to develop advanced vehicles and systems for transportation, and to develop viable vehicle systems that are integral to DOE transportation initiatives. NREL also works with energy companies and manufacturers of vehicles and engines to develop advanced motor vehicle fuels for improved energy and environmental performance. A systems approach is used to develop optimized engine management, fuel, and emission control technologies.

Wind Energy: Through the National Wind Technology Center (NWTC), NREL develops, improves, and demonstrates the viability of wind technology for electricity generation and facilitates its utilization throughout the world.

\subsection{Site and Facility Description}

NREL facilities occupy five separate locations in Jefferson County, Colorado, near the city of Denver, and one within the boundaries of the City and County of Denver. The five facilities in 
Jefferson County include the Denver West Office Park (DWOP), Golden Hill (GH), the South Table Mountain site (STM), the Joyce Street Facility (JSF), and the NWTC. The Renewable Fuels and Lubricants Research Laboratory (ReFUEL) is located within the city limits of Denver. The DWOP and STM sites are approximately two miles $(3.2 \mathrm{~km})$ east of Golden and 12 miles $(19.3 \mathrm{~km})$ west of central Denver. The NWTC is located near the intersection of Highways 93 and 128, between Boulder and Golden, and is approximately 15 miles $(24.2 \mathrm{~km})$ north of the STM site. The JSF is located at 6800 Joyce Street, about 5.5 miles $(8.9 \mathrm{~km})$ north of the DWOP and STM sites. The ReFUEL facility is located with the Regional Transportation District (RTD) District Shops and Operation Center (DSOC) at 1900 31st Street, Denver, about 12 miles east of the STM and DWOP sites. Figure 1 illustrates the locations of the STM, DWOP, NWTC, and JSF sites on a regional map. The location of the ReFUEL facility is shown in Figure 2. Figure 3 provides a more detailed map of the STM site, and Figure 4 provides detail for the NWTC site.

The STM and NWTC sites are the two main sites where research operations are conducted and will be addressed separately in the discussion of environmental features. The DWOP is leased space used primarily for administrative functions and limited research activities. The JSF is also a leased space that is currently used for storage. The ReFUEL facility is a leased facility that consists of a small shop complex housed within the RTD/DSOC facility. NREL performs engine-testing activities pertaining to fuels and lubricants at the site.

Recent changes to the NREL South Table Mountain campus include a new heating plant and a photovoltaic array and the on-going construction of the new Research Support Facility. The Renewable Fuels Heat Plant (RFHP) was constructed between the Field Test Laboratory Building and the Solar Energy Research Facility in 2008 to provide heat to STM campus buildings. Using wood chips from a variety of sources along Colorado's Front Range, the RFHP provides hot water through underground pipes to heat all of NREL's facilities on the STM site. The RFHP has an estimated output of 29 billion BTUs per year; however, it saves more than 40 billion BTUs of natural gas due to conversion efficiencies. The RFHP will offset $\mathrm{CO}_{2}$ emissions of 4.8 million pounds per year when fully operational.

In addition to the RFHP, a large solar panel array was constructed on NREL property on top of STM. The $750 \mathrm{~kW}$ Mesa Top Photovoltaic Array is expected to produce 1.2 gigawatt hours of solar electricity per year. The array ensures NREL will exceed the EPA goal of $7.5 \%$ of a federal facility's electricity coming from renewable sources. In fact, the installation alone could provide as much as $7.2 \%$ of the electricity the lab uses. It will offset 2.4 million pounds of $\mathrm{CO}_{2}$ production annually.

Construction of the Research Support Facility (RSF) continued throughout CY2009, with a scheduled completion date of June 2010. The RSF is a 222,000 square foot building which will house 800 employees and is so energy efficient that it will only consume as much energy as can be generated by renewable power on or near the building. It is being designed to meet the stringent standards of the U. S. Green Building Council's Leadership in Energy and Environmental Design (LEED) program to achieve a Platinum rating. Supplementing the ongoing construction of the RSF in 2009 was the South Table Mountain (STM) Infrastructure Project, which extends the current utility infrastructure to support new facilities and the buildout of the STM. 


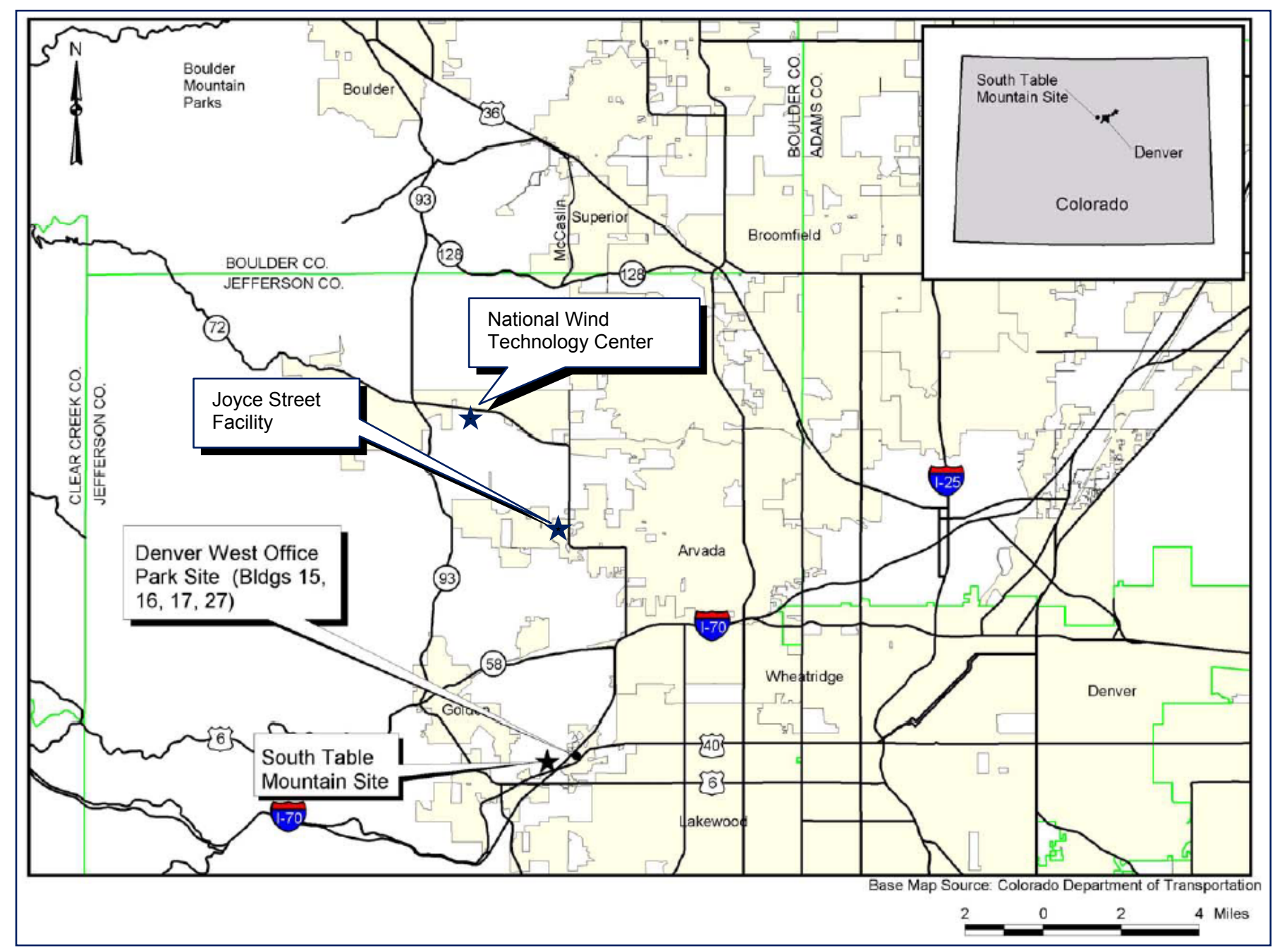

Figure 1. Regional map showing NREL locations in Jefferson County, CO 


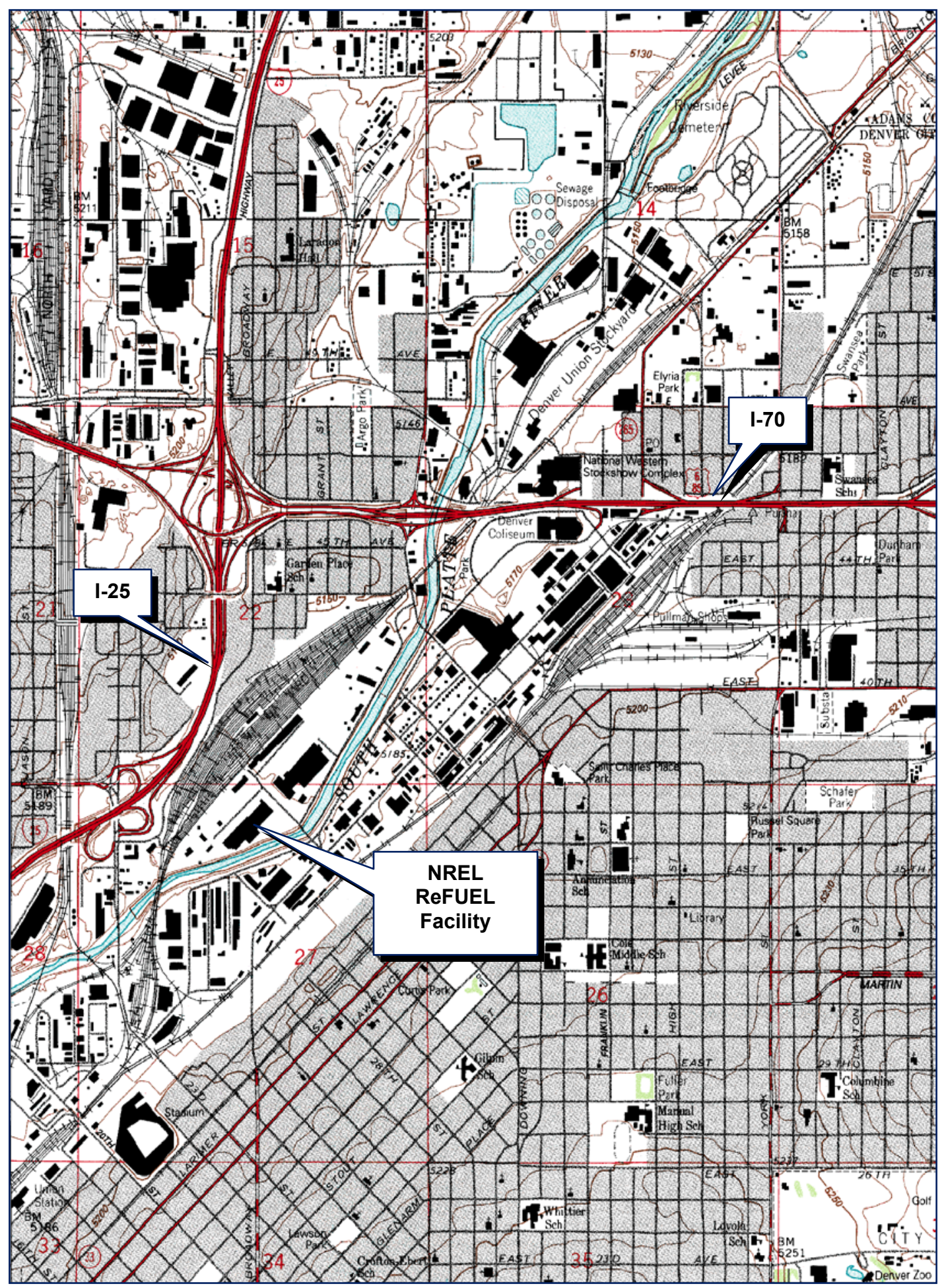

Figure 2. ReFUEL Facility location map, located in Denver County, CO 


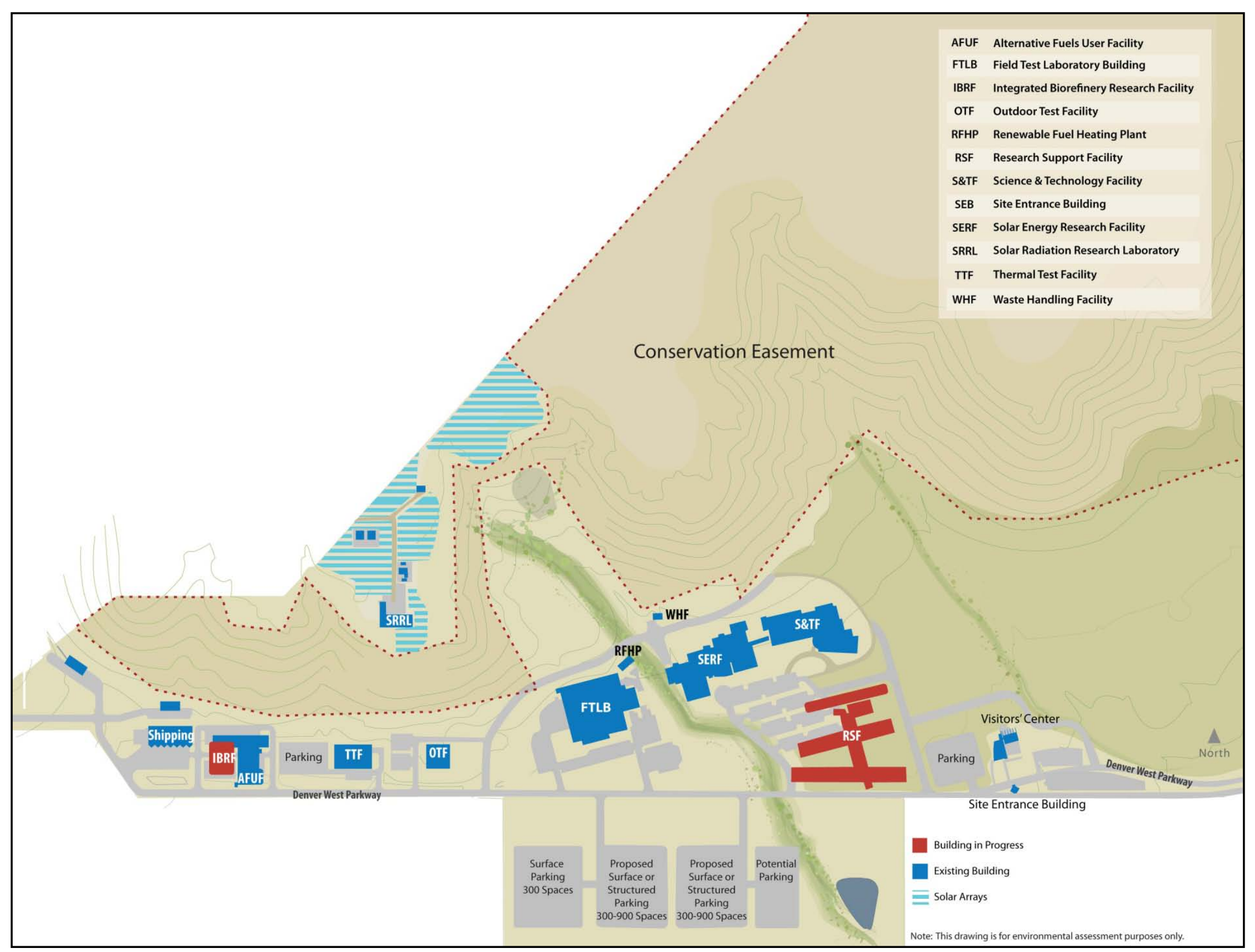

Figure 3. STM site detail 


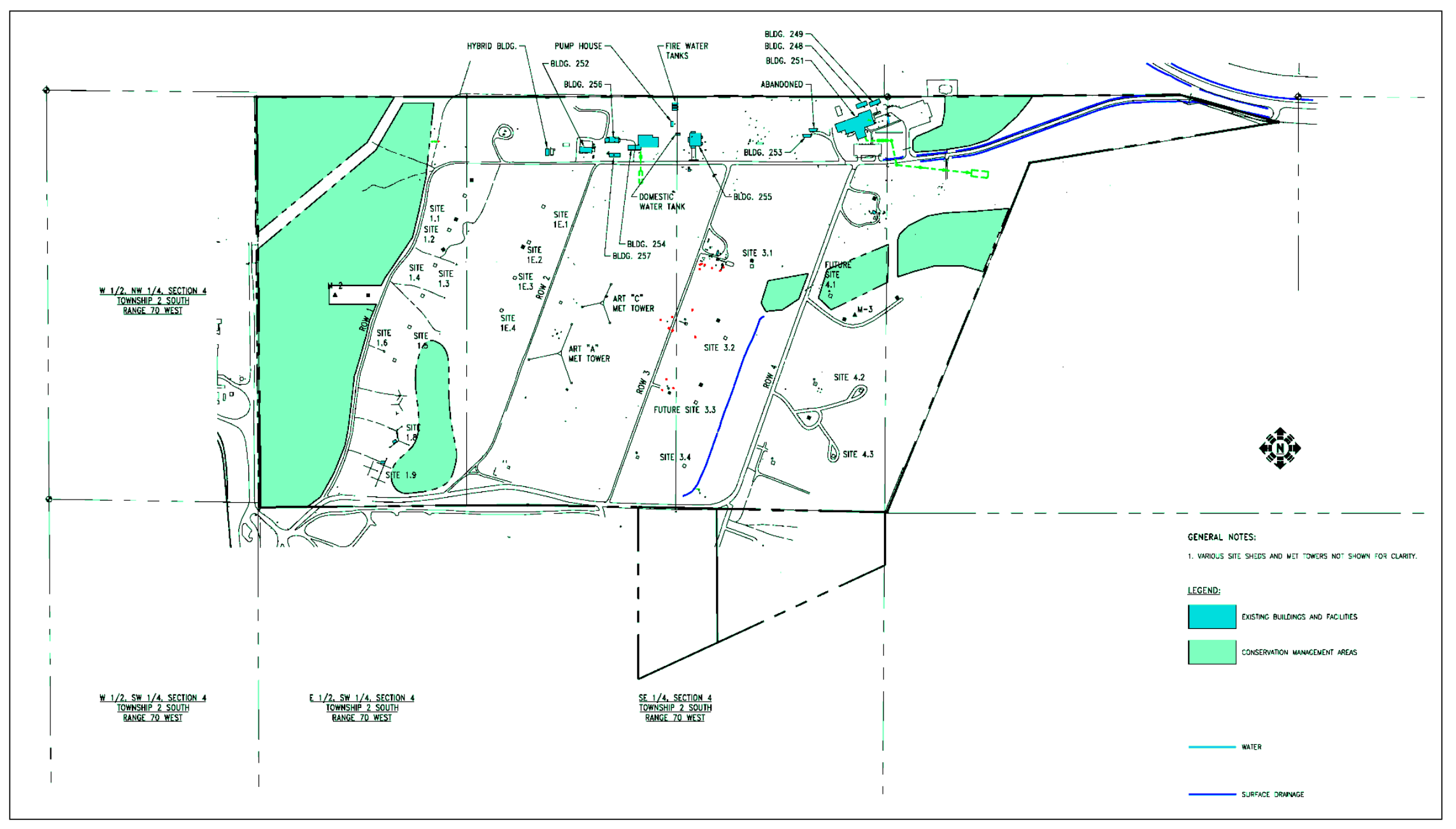

Figure 4. NWTC site detail 


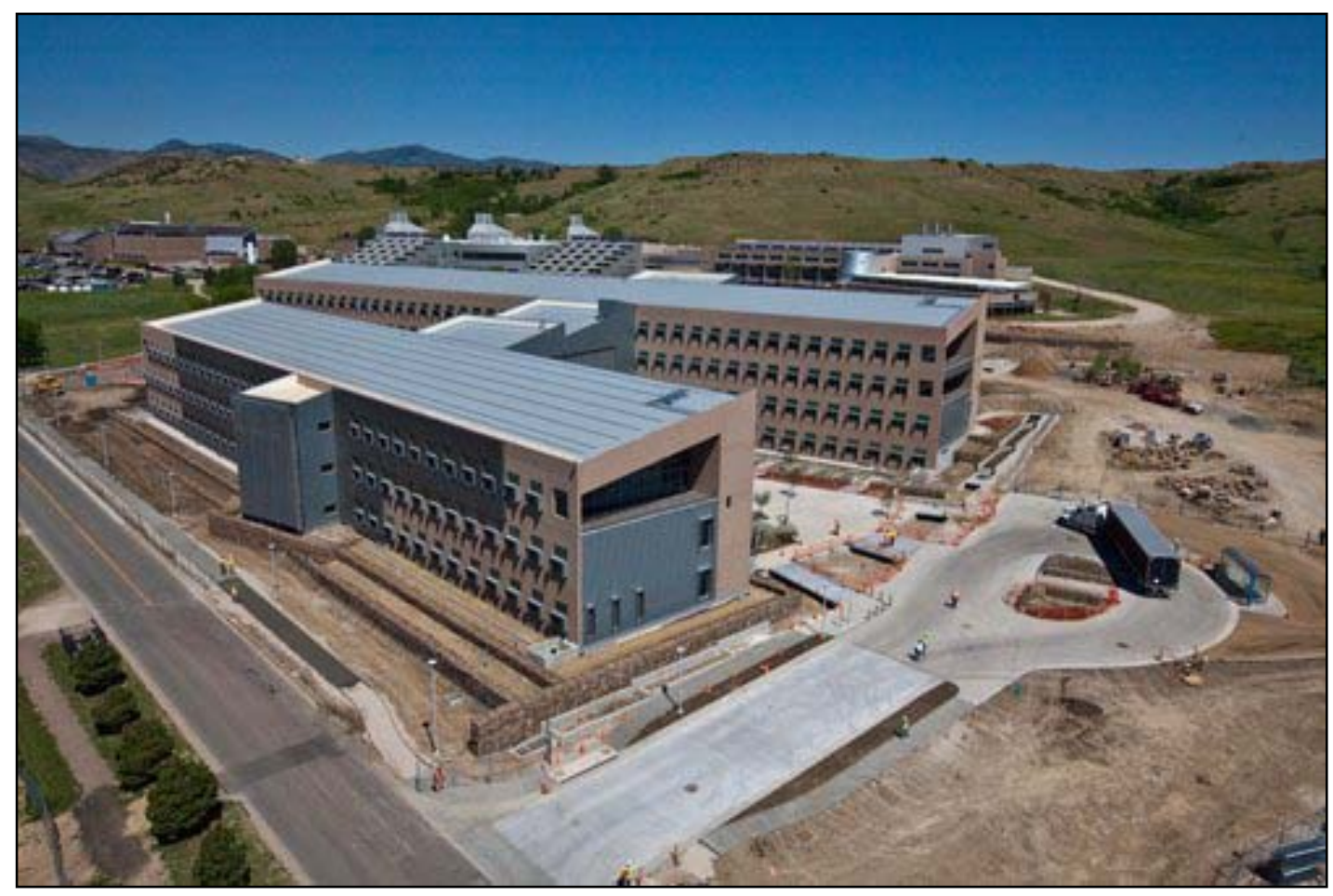

Figure 5. Research Support Facility

PIX\# 17755

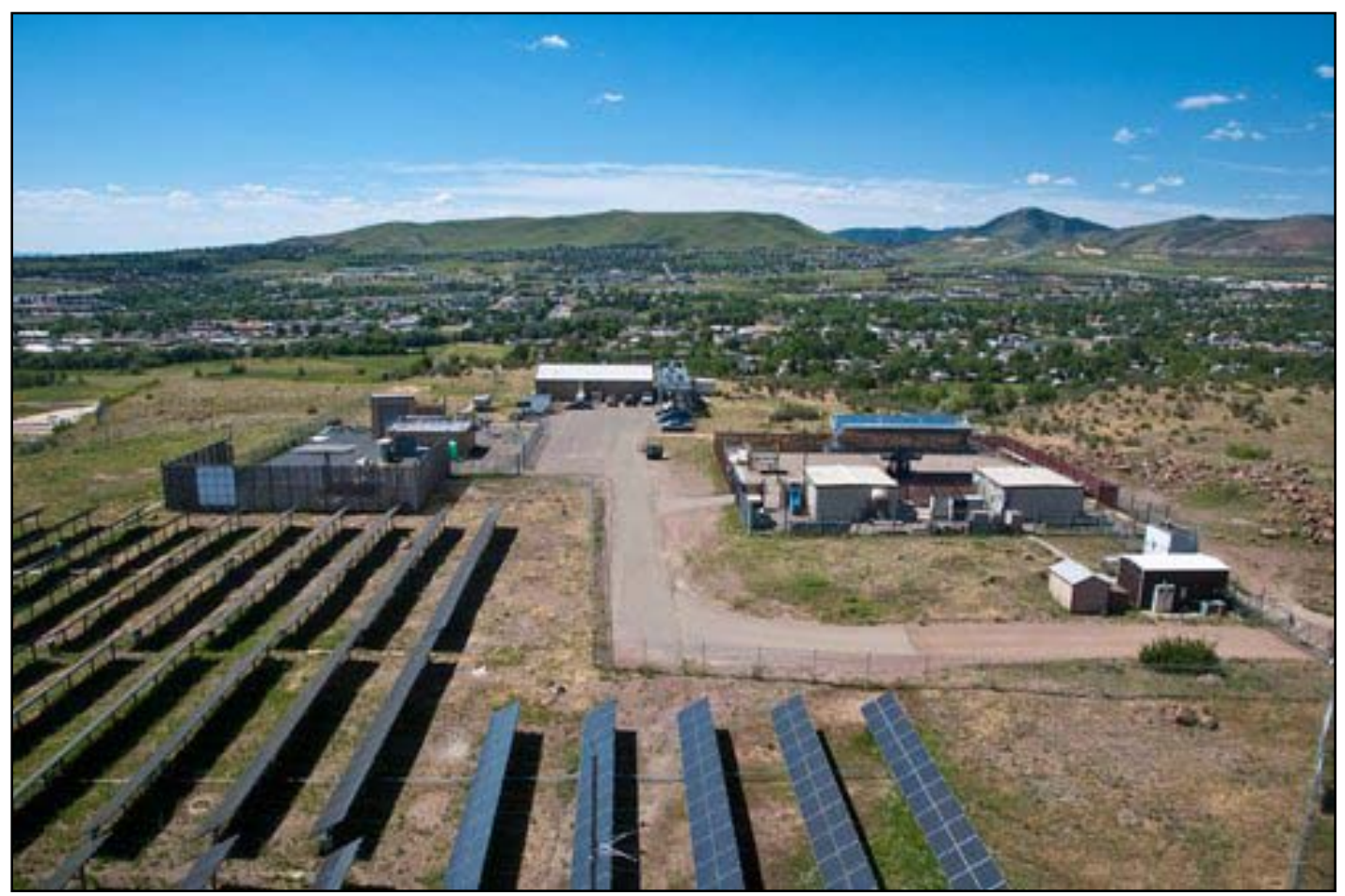

Figure 6. South Table Mountain Mesa Top

PIX\# 17776 


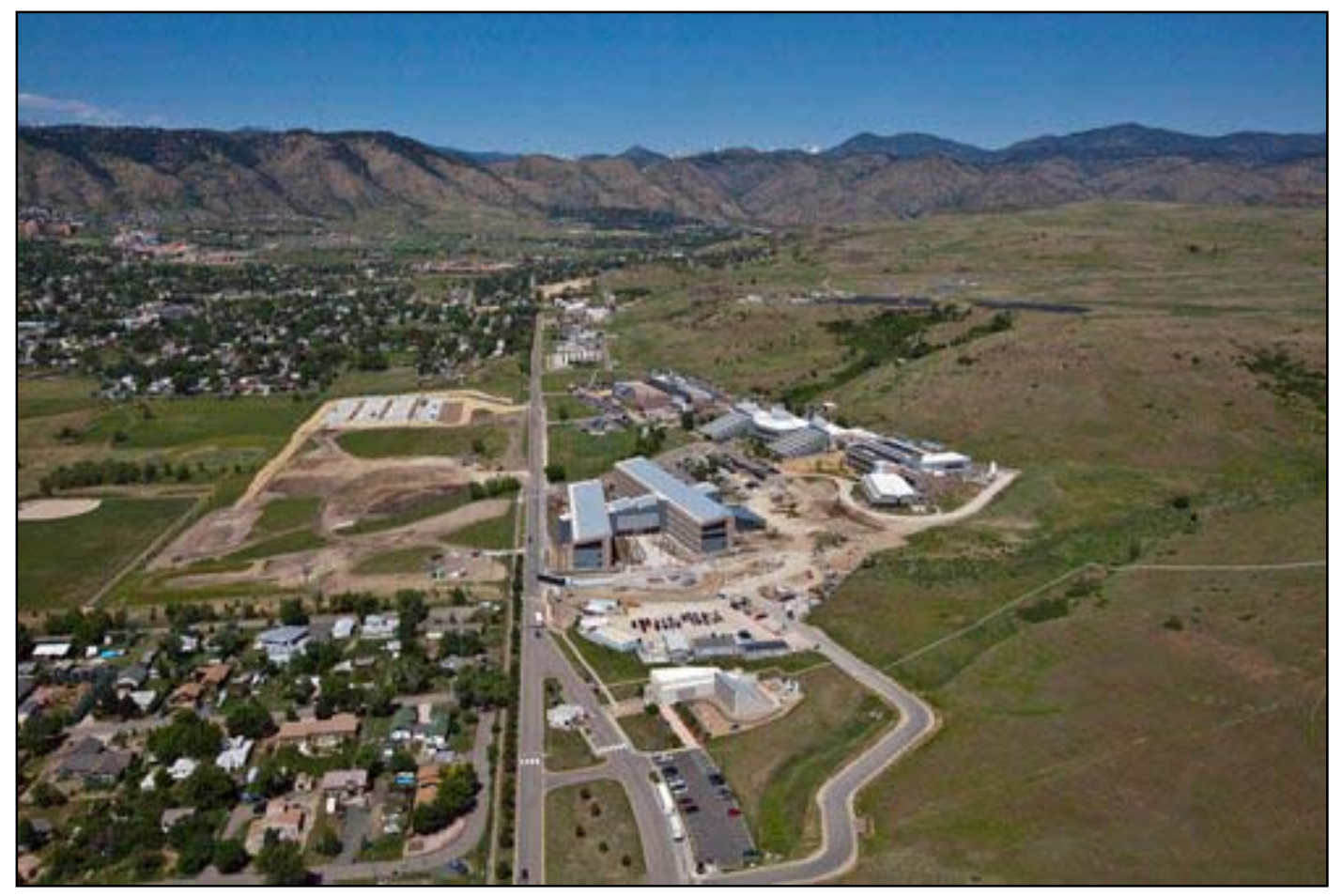

Figure 7. South Table Mountain Campus

PIX\# 17761

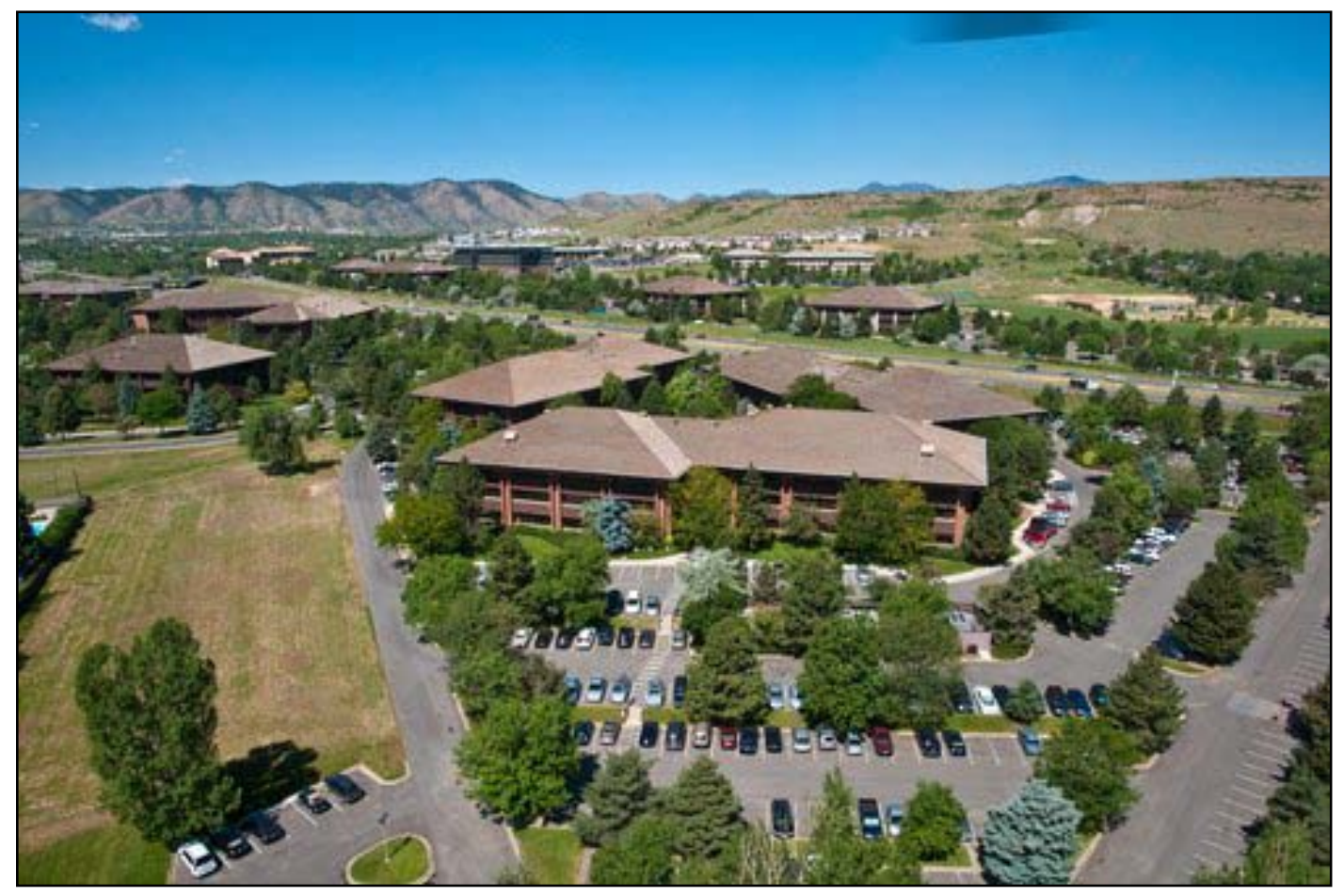

Figure 8. Denver West Office Park

PIX\# 17798 


\subsubsection{South Table Mountain Site}

\subsubsection{Geology, Soils, and Hydrogeology}

The South Table Mountain (STM) site is a roughly triangular parcel of land occupying portions of the top, sides, and lower south-facing slopes of STM. STM is composed of sedimentary rocks below a basalt lava cap, which is quite resistant to erosion. The STM feature is a mesa that stands about 150 meters above the adjacent lowlands. The mesa was formed as weak sedimentary rocks surrounding the lava were eroded away, leaving the lava-capped mesa in relief. Below the lava caprock, the sedimentary rocks are part of the Denver Formation that consists of layers and lenses of claystone, sandstone, and conglomerate. Sedimentary rocks of the Arapahoe Formation underlie the Denver Formation.

Both the Arapahoe and Denver Formations are considered to be aquifers in portions of the Denver Basin. The Denver Formation underlies the areas on which most NREL construction has taken place. Groundwater on the STM site occurs primarily in the weathered and fractured silts and sands of the Denver Formation. There may also be some groundwater in the form of perched aquifers below the basaltic lava cap on the STM, and within the materials above the Denver Formation, which are largely the result of stream deposits. Groundwater flow on the site is in a southeasterly direction.

The soil covering the top of the STM is lavina loam. Loam is composed of a mixture of clay, sand, silt, and organic matter. The loam on the mesa top is a shallow, well-drained clayey soil. Soil on the upper side slopes of the STM is also a loam consisting of extremely stony soils with significant amounts of clay. Much of the remainder of the site, including the area designated for major development, has a deep, well-drained soil referred to as Denver clay loam. It consists of clayey material containing some calcium carbonate. There are also two smaller soil areas on the southwestern portion of the site, both of similar character to other site soils - cobbly clay loam and very stony clay loam.

\subsubsection{Surface Water}

About $90 \%$ of the surface drainage off the site, both from the mesa top and across the lower portions of the site, is in the southerly direction toward Lena Gulch (a tributary of Clear Creek). Surface water from two drainage ways on the easternmost portion of the site ultimately flows into Lena Gulch.

There is no permanent stream flow on the STM site. Only occasional flow derived from extended periods of precipitation, usually during the late winter and early spring, is found in the drainage channels, with seasonal springs evident along some of the mesa slopes. There is one seep on the mesa top that is often active throughout much of the year, but the water infiltrates and evaporates quickly during the dry season.

\subsubsection{Vegetation}

Two primary vegetation types are present on the STM site: grasslands and shrublands. The most common plant communities on the STM site are mixed grasslands, composing more than $80 \%$ of the vegetation on the site. These communities are generally dominated by short- and mid-grass species. Two primary upland shrub communities occur on the STM site: mountain mahogany shrublands, found on the shallow soils of the mesa, and upland shrublands, occurring in drainages lacking active channels as well as drainages with associated wetlands. Field surveys have identified limited wetland/riparian areas along drainages. The wetland communities identified on the STM site are a minor component of the total vegetation cover, accounting for less than $1 \%$ of the vegetation over an 
area of less than 0.3 hectares ( 0.75 acres). Riparian shrub communities also occur adjacent to the emergent wetlands.

\subsubsection{Wildlife}

A wildlife survey was conducted on the site during 1986 and 1987, and additional surveys were done in 1999 over the conservation easement property. A survey to update the existing data began in 2004 and was completed in 2005 (see Section 5.11 for more detail). Mammals seen using the site during the surveys include mule deer, coyotes, gray foxes, red foxes, raccoons, long tailed weasels, striped skunks, spotted skunks, badgers, bobcats, mountain lions, rabbits, and yellow-bellied marmots.

Seventeen species of birds have been observed on the STM site, along with two species of raptors: American kestrels and two nesting pairs of red-tailed hawks. Amphibian species and snakes are known to inhabit the area as well.

\subsubsection{Land Use}

The STM site is a 327-acre area predominantly bordered by open grassland zoned for recreation and light-commercial activity. Portions of the community of Pleasant View are located immediately to the south and west of the western portions of the STM site. Pleasant View has constructed a recreational park immediately south of the STM site. Offices, shops, and a tree nursery owned by the Colorado State Forest Service are located at the far western edge. Undeveloped state land and a Colorado State Highway Patrol pursuit driver-training track are located along the northwestern boundary of the STM site on top of the mesa. Jefferson County open space wraps around the northern and the eastern edge of the site. Portions of the DWOP and apartment homes lie to the east.

More than half of the STM site (177 acres) has been set aside in a conservation easement. No development is allowed on that land, with the exception of some existing utility easements and recreational trails to be established by Jefferson County Open Space. Trail development planned for implementation in phases by the County began in 2004 (see Section 6.0 for more detail).

\subsubsection{National Wind Technology Center}

\subsubsection{Geology, Soils, and Hydrogeology}

The National Wind Technology Center (NWTC) site is located on a plain formed by stream deposits. The uppermost geological layer beneath the site is known as the Rocky Flats Alluvium (RFA). It is composed of cobbles, coarse gravel, sand, and gravelly clay. Below the RFA are the Laramie Formation, Fox Hills Sandstone, and Pierre Shale. These rock formations consist primarily of claystones with some siltstones. Unconfined groundwater flow occurs in the RFA toward the east/southeast, and small perched zones are common. Groundwater occurs as confined aquifers in the deeper bedrock formations (EG\&G Rocky Flats, Inc. 1992).

The NWTC has a strongly developed soil defined as a very cobbly, sandy loam. The soil is characterized by a large amount of cobble and gravel in the soil volume, and subsoil dominated by clay (USDA 1995).

\subsubsection{Surface Water}

The area surrounding the NWTC site is drained by five streams: Rock Creek, North Walnut Creek, South Walnut Creek, Woman Creek, and Coal Creek. Rock Creek flows eastward and is located southeast of the NWTC. North Walnut Creek and South Walnut Creek flow eastward into the Great 
Western Reservoir. Woman Creek drains eastward into Standley Lake. Coal Creek flows in a northeasterly direction across the City of Boulder open space north of the NWTC.

The majority of the NWTC drains into a tributary to Rock Creek. Some of the northern portions of the site drain into Coal Creek or its tributaries.

\subsubsection{Vegetation}

The NWTC is located in the transition area between the Great Plains and the Rocky Mountains (Plantae Consulting Services 2000). This location results in a flora that contains elements from both mountain and prairie ecosystems, and associations that represent residual tall grass prairie, shortgrass plains, ponderosa pine woodland, and foothill ravine flora (Plantae Consulting Services 2000).

A vegetation study conducted between August 1999 and August 2000 identified 271 vascular plant species and defined five major habitat types on the NWTC site, including: seasonal wetlands/or ephemeral hydric soils, woodlands, shrublands, mixed grasslands, and disturbed areas.

Along the northwestern ridge is a Ponderosa Pine woodland area. Vegetation found in this area includes woody species with an understory of grasses, forbs, and shrubs.

\subsubsection{Wildlife}

Prior to 1975, livestock heavily grazed the NWTC site, damaging a majority of the native vegetation. A wildlife survey was conducted in 1992 for the entire Rocky Flats Plant and buffer zone area, including the NWTC site. Signs or tracks of bears and mountain lions were identified. Other mammals known to feed at the site are mule deer, coyotes, desert cottontail rabbits, white-tailed jackrabbits, black-tailed jackrabbits, deer mice, prairie voles, and thirteen-lined ground squirrels. Approximately 20 different species of birds were sighted at or near the site. Raptor (birds of prey) surveys were conducted at the NWTC in 1994 and 1995, and identified seven raptor species on or in the vicinity of the site. An avian survey was also conducted in 2001 to 2002 (see Section 5.11). Although seldom seen, rattlesnakes, bull snakes, racers, and several other reptilian and amphibian species are known to occupy the area.

\subsubsection{Land Use}

The NWTC facility occupies a 305-acre area surrounded largely by open space and grazing land. The former Rocky Flats Environmental Technology Site land borders the NWTC to the southeast, and a sand and gravel mining and processing operation is located along the southern and western boundaries of the site. A blasting company also has a small installation along the western site boundary.

\subsubsection{Denver West Office Park}

The Denver West Office Park (DWOP) is a relatively flat, landscaped office complex occupied by a number of four-story buildings, parking lots, and common areas. NREL-leased facilities at the DWOP are located approximately in the geographic center of the development, with the exception of one NREL-leased facility just north of West Colfax. The DWOP is bordered on the south by commercial areas (West Colfax strip), on the west by the Pleasant View residential area, Camp George West facility, and the STM site. The DWOP is within the City of Lakewood. 


\subsubsection{Joyce Street Facility}

The Joyce Street Facility (JSF) is located in a commercial area surrounded by agricultural land, residential neighborhoods, and small businesses. It is currently used by NREL primarily as warehouse space only. Support activities and limited dry lab research activities are currently conducted at the facility, and there are no staff offices at JSF.

\subsubsection{Renewable Fuels and Lubricants Research Laboratory}

The Renewable Fuels and Lubricants Research Laboratory (ReFUEL) is used for research, testing, and support activities related to advanced fuels, engines, and vehicles to objectively evaluate performance, emissions, and energy efficiency impacts. The laboratory is also used to evaluate and develop heavy hybrid electric vehicles.

The ReFUEL is a small shop complex housed within the RTD/DSOC facility. The RTD/DSOC facility occupies approximately 22 acres of land and serves as the primary maintenance facility for RTD's bus and light rail train systems. The area around the RTD/DSOC facility consists of commercial and light industrial development.

The site lies on relatively flat terrain with a slight gradient to the northwest. The general area is highly developed with concentrated industrial and commercial activities. Very little natural vegetated habitat exists on site or in the immediate vicinity. There are trees and shrubs lining the South Platte River adjacent to the site's south, east, and northeast borders.

\subsection{Site Environmental Conditions/Features}

Photos for each site documenting the site features and development are included at the end of this section. Figures 5, 6, 7, and 8 show the STM and DWOP sites, and Figures 9 and 10 provide images of the NWTC site. The views on the STM site also illustrate the conservation easement property and the Camp George West property acquired in 1999.

\subsubsection{Climate}

The climate for the geographic region of NREL operations is classified as semi-arid, typified by limited precipitation, low relative humidity, abundant sunshine, and large daily and seasonal temperature variations.

The area experiences moderate precipitation, with an average annual rainfall of less than $50 \mathrm{~cm}(20$ inches). Almost half of the annual precipitation occurs from March to June. Summer showers contribute $33 \%$ of the annual precipitation total. Precipitation begins to decrease significantly in the fall, and reaches the minimum during winter. Winter is the driest season, contributing less than $10 \%$ of the annual precipitation, primarily in the form of snowfall.

Spring is a season of unstable air masses with strong winds along the foothills and the Front Range. The highest average snowfall occurs in March, and the STM site can generally expect to experience at least one heavy snowstorm with totals exceeding 15 to $25 \mathrm{~cm}$ (6 to 10 inches).

The solar radiation (sunlight energy) of the region is excellent for outdoor research and testing of solar energy conversion devices and systems. Sunshine is abundant throughout the year and remarkably consistent from month to month, season to season. 


\section{Compliance Summary}

\subsection{Laws and Regulations}

\subsubsection{Air Quality Protection}

The Colorado Department of Public Health and Environment (CDPHE) administers the Clean Air Act implementing regulations for all point sources (facilities or other types of operations) in Colorado, under authority delegated by the U.S. Environmental Protection Agency (EPA). NREL is not a major source for air pollutants, but does hold two site-wide permits for particulate air emissions from construction, one air emissions permit for a pilot-scale research project, and one air permit for the operation of the RFHP, a woodwaste-fired heating plant. Detailed information about NREL's air quality protection program is provided in Section 5.1.

National Emissions Standards for Hazardous Air Pollutants (NESHAP) requirements specific to radiological emissions from DOE facilities are regulated by the EPA. Details are provided in Section 5.16 .

In 2009, NREL filed a Malfunction Event Report with the Air Quality Control Division of CDPHE. On March 19, wet fuel introduced into the RFHP during start up resulted in a 30 minute period during which the opacity of the stack emissions was estimated at $60 \%$. This exceeded the allowable level of $30 \%$ opacity during start up for no more than 6 minutes. The report also described the corrective actions taken by the operators to prevent such events in the future.

\subsubsection{Drinking Water Quality Protection}

Drinking water quality is regulated for all public water suppliers in Colorado by the CDPHE, under authority delegated by the EPA. NREL purchases water that is delivered by truck to the NWTC, and holds a public water supply identification number to operate the NWTC distribution system. NREL has been conducting increased monitoring since the fourth quarter of 2006 for disinfection byproducts. Detailed information about system performance is provided in Section 5.2.

In 2009, NREL had no drinking water compliance issues.

\subsubsection{Groundwater Quality Protection}

Colorado groundwater quality standards are established by the CDPHE. Permits for groundwater wells are issued by the state engineer's office. NREL has no known groundwater contamination and has obtained drilling permits for all of its monitoring wells. Detailed information about NREL's groundwater program is provided in Section 5.3.

In 2009, NREL had no groundwater compliance issues.

\subsubsection{Wastewater}

Wastewater from the majority of the STM site and the Denver West Office Park is discharged into the Pleasant View Water and Sanitation District's (Pleasant View) collection system, and flows to the Metropolitan Wastewater Reclamation District (Metro) treatment plant. The federal Clean Water Act and Colorado Water Quality Control Act regulations are administered at NREL's STM and DWOP via Pleasant View and Metro pretreatment program requirements. NREL's wastewater discharge policy is in conformance with Metro's discharge requirements. 
Wastewater at the NWTC site flows into two individual sewage disposal systems (septic and leach fields). These are regulated by CDPHE; inspection and permit issuance have been delegated by CDPHE to the Jefferson County Department of Health and Environment. There is also one individual sewage disposal system at the Solar Radiation Research Laboratory (SRRL) on the mesa top at the STM site. As is the case with NWTC septic systems, the mesa top system regulations are administered by Jefferson County. Additional detail about NREL's wastewater discharge program can be found in Section 5.4.

In 2009, NREL had no wastewater compliance issues.

\subsubsection{Surface Water Quality Protection}

Stormwater discharge regulations are administered by the EPA at federal sites in Colorado. As a result, NREL falls under the EPA Construction General Permit (CGP) program for the STM and NWTC sites for stormwater discharge from construction activities. Permit coverage for individual NREL activities is obtained when permit thresholds are triggered.

At the STM, a Notice of Intent (NOI) was filed with the EPA in 2009 for the construction of the Integrated Bio-Refinery Facility (IBRF) and the STM Infrastructure project. These activities continued through 2009.

At the NWTC, a NOI was filed with EPA in 2009 for the Sun Edison 1 megawatt photovoltaic array field. This project occupies about 8 acres in the western portion of the NWTC.

In 2009, NREL had no surface water compliance issues.

\subsubsection{Waste Management}

The Resource Conservation and Recovery Act (RCRA) established federal authority over hazardous waste. In Colorado, the CDPHE administers hazardous waste regulations under authority delegated by the EPA. NREL holds five EPA generator identification numbers for each of its sites. NREL's waste management program is outlined in Section 5.6. Pollution prevention efforts at NREL are described in Section 5.9.

In 2009, NREL had no waste management compliance issues.

\subsubsection{Storage Tanks}

NREL has no underground storage tanks containing hazardous materials. Aboveground storage tanks (ASTs) that are larger than 660 gallons are regulated in Colorado by the Colorado Department of Labor and Employment's Oil Inspection Section. NREL has two tanks larger than 660 gallons on the STM site that are registered with the Colorado Department of Labor and Employment. Details about NREL's AST program are provided in Section 5.7.

No spills or releases from NREL's ASTs occurred during 2009.

\subsubsection{Threatened and Endangered Species/Species of Concern}

Wildlife is protected by a number of federal laws, including (but not limited to) the Endangered Species Act, the Migratory Bird Treaty Act, and the Golden and Bald Eagle Protection Act. The Endangered Species Act also protects threatened and endangered plant species. State laws designate and protect rare or unique plants and animals as well. No threatened or endangered species or species 
of concern have been documented on NREL's sites. Details of NREL's wildlife and vegetation surveys are provided in Sections 5.10 and 5.11.

In 2009, NREL had no compliance issues regarding wildlife.

\subsubsection{EPCRA Compliance and Prevention of Toxic Releases}

Executive Order (EO) 13423 and DOE Order 450.1A outline requirements for Superfund Amendments and Reauthorization Act (SARA) Title III, Emergency Reporting and Community Right-to-Know Act (EPCRA) compliance, and Toxic Release Inventory reductions for DOE facilities. NREL maintains hazardous materials permits with West Metro Fire Rescue (West Metro) and provides chemical inventory information to West Metro for the STM site and Building 16 in the DWOP. NREL's ReFUEL facility holds a Hazardous Materials Permit issued by the Denver Fire Department.

Federal facilities that use, produce, or store extremely hazardous substances in quantities above specific release thresholds are required to report on their inventory to various federal, state, and local emergency planning authorities, as required by requirements Emergency Reporting and Community Right-to-Know Act (EPCRA) provisions in Title III of the Superfund Amendments and Reauthorization Act (SARA). A summary of the EPCRA requirements and the applicability to NREL is presented in the table below.

In 2009, NREL facilities had no releases exceeding the reportable quantity (RQ) of any material reportable under EPCRA. As a research and development laboratory, NREL does not manufacture or process any materials on the SARA Section 313 list in excess of the applicable threshold planning quantity. And during 2009, the laboratory did not otherwise use any materials on the SARA Section 313 list in quantities exceeding the applicable threshold planning quantity. NREL's compliance with EPCRA requirements is detailed in Section 5.8.

Table 1. Status of EPCRA Reporting

\begin{tabular}{|l|l|l|}
\hline \multicolumn{1}{|c|}{ EPCRA Section } & \multicolumn{1}{c|}{ Description of Reporting } & \multicolumn{1}{c|}{ Status } \\
\hline EPCRA Sec. 302-303 & Planning Notification & Reporting threshold not met $^{*}$ \\
\hline EPCRA Sec. 304 & EHS Release Notification & Reporting threshold not met \\
\hline EPCRA Sec. $311-312$ & MSDS/Chemical Inventory & Reporting threshold not met \\
\hline EPCRA Sec. 313 & TRI Reporting & Reporting threshold not met \\
\hline
\end{tabular}

* NREL maintains hazardous materials permits with West Metro Fire Rescue (West Metro) and reports chemical inventory information to West Metro for the STM site and Building 16 in the DWOP. NREL's ReFUEL facility holds a Hazardous Materials Permit issued by the Denver Fire Department which requires an annual report of the chemical inventory.

NREL maintains an Emergency Management Policy (8-4) and supporting lab-level programs for credible on-site emergencies. In 2009, the NREL Emergency Management Manual was updated to include a complete description of the lab's activities that demonstrate compliance with all applicable emergency requirements of the Colorado Hazardous Waste Regulations. Hazardous material releases are specifically identified as a credible emergency, and response procedures are in place. These procedures are routinely practiced by internal response groups and with external emergency response agencies. In 2009, the NREL Emergency Response Team (ERT) and West Metro worked together on an actual event at the Solar Energy Research Facility, described in Section 3.4.1. 


\subsubsection{Cultural Resources Protection}

Various laws, including but not limited to, the National Historic Preservation Act and the Native American Graves Protection and Repatriation Act, protect cultural resources. NREL has two sites listed on the National Register of Historic Places (National Register) on its STM site. There are no known eligible sites at the NWTC (see Section 5.14).

In 2009, NREL provided the State Historic Preservation Office (SHPO) with the Environmental Assessment for the proposed construction activities on STM, including the STM Infrastructure, Energy Systems Integration Facility (ESIF), and the south access road. There were no comments on the Infrastructure or ESIF projects, but the SHPO reserved comment on the access road until a final determination is made on its alignment.

\subsection{DOE Order 450.1A, Environmental Protection Program}

DOE Order 450.1 required sites to implement an Environmental Management System (EMS) by integrating them with the site's Integrated Safety Management System. Sites were required to have an EMS in place by December 31, 2005. The revised Order 450.1A requires that EMSs now be structured according to International Organization for Standardization (ISO)14001 requirements by June 2009. NREL's implementation of its EMS is described in Section 4.0 of this report.

\subsection{Executive Orders}

There are a number of Executive Orders (EO) related to the environment that direct DOE activities and subsequent implementation at NREL. A few representative EOs are discussed below.

\subsubsection{Executive Order 13514, Federal Leadership in Environmental, Energy, and Economic Performance}

On October 5, 2009, the President signed EO 13514. This Order requires all federal agencies and departments to "increase energy efficiency; measure, report, and reduce their greenhouse gas emissions from direct and indirect activities; conserve and protect water resource through efficiency, reuse, and stormwater management; eliminate waste, recycle, and prevent pollution; leverage agency acquisitions to foster markets for sustainable technologies and environmentally preferable materials, products, and services; design, construct, maintain, and operate high performance sustainable buildings in sustainable locations; strengthen the vitality and livability of the communities in which federal facilities are located; and inform federal employees about and involve them in the achievement of these goals." NREL began implementation of this EO with an assessment of greenhouse gas emissions, and initiated plans for further activities in 2010.

\subsubsection{Executive Order 13423, Strengthening Federal Environmental, Energy, and Transportation Management}

On January 24, 2007, the President signed EO 13423. This Order requires all federal agencies and departments to "conduct their environmental, transportation, and energy-related activities under the law in support of their respective missions in an environmentally, economically, and fiscally sound, integrated, continuously improving, efficient, and sustainable manner" (72 FR 3919). One of the provisions of the EO is to reduce or eliminate the use of toxic materials. While NREL's research needs cannot replace all toxic materials, efforts are made to reduce the quantities of toxic materials used at the laboratory. In 2009, chemical safety training materials were enhanced to encourage researchers to find less toxic alternatives wherever possible. 


\subsubsection{Executive Order 11988, Floodplains Management}

EO 11988 was implemented in support of the National Environmental Policy Act (NEPA), the National Flood Insurance Act of 1968, and the Flood Disaster Protection Act of 1973 to minimize the adverse impacts associated with development and modification of floodplains. According to maps generated by the Jefferson County Department of Highways and Transportation as part of its urban drainage studies, NREL's STM site does not contain any floodplains, and no floodplains have been identified at the NWTC. As a best management practice (BMP), however, all construction activities that may cross a drainage channel are designed to meet the 100-year flood control standards (designed to withstand the equivalent of a 100-year flood). Actions with the potential for environmental impact that are undertaken by NREL at subcontractor facilities are assessed for potential impacts on floodplains and wetlands at those sites through the use of an environmental checklist.

\subsubsection{Executive Order 11990, Wetlands Protection}

Under EO 11990, each federal agency must provide leadership and take action to minimize the destruction, loss, or degradation of wetlands, and to preserve and enhance the natural and beneficial values of wetlands. Limited wetland areas totaling less than 0.3 hectares $(0.75$ acres $)$ occur on the STM site. These are narrow, linear wetlands supporting spikerush, baltic rush, sedges, bluegrass, hemlock, and field mint. Wetland areas at the NWTC are extremely limited in extent as well. These areas, along the site's eastern boundary, total less than 0.4 hectares $(1$ acre).

In 2009, NREL had no compliance issues regarding environment-related EOs.

\subsection{Permit Summary}

Appendix A contains a table summarizing NREL's permits, registrations, and notifications. 


\section{NREL's Role in the Environment-Global and Local}

As the nation's premier resource for renewable energy information, research, and technology, NREL has a unique role in supporting the "nation's energy and environmental goals." NREL has a positive environmental presence, both in the operation of the laboratory facilities and in the major impacts to global conditions by research done at NREL. Laboratory operations follow the NREL Environmental Management System (EMS), which is described in detail below and in the following chapter. NREL has earned its designation as an environmental leader by implementing a rigorous EMS, focusing environmental strategies through such longstanding NREL organizations as Sustainable NREL, and promoting sound environmental practices.

NREL's mission is stated succinctly:

NREL develops renewable energy and energy efficiency technologies and practices, advances related science and engineering, and transfers knowledge and innovations to address the nation's energy and environmental goals.

Among the environmental imperatives addressed by NREL, carbon mitigation and land and water use are critical to the 21st century. A major change in the nation's energy policy has spurred new research efforts at NREL to help address these issues. Renewable energy technologies will be critical to reversing the devastating effects of climate change and to moving forward to energy independence.

\subsection{Energy Policy Updates}

In 2008, there was a major shift in the energy policy of the United States with the passage of the Energy Independence and Security Act (EISA) which mandates significant changes in the energy production and use in the United States over the coming decades. The EISA has numerous provisions impacting vehicle fuel efficiency, including transportation electrification; funding for increased biofuel research and production; expanded research on solar, geothermal, marine, and hydrokinetic renewable technologies; support for research into carbon sequestration technologies; and provisions that will result in a modernization of the electrical transmission system known as Smart Grid. NREL has a critical role in helping the nation meet the legislative goals set in the EISA.

The Energy Information Agency (EIA), an independent arm of DOE, produces a summary document of energy use and projections called the Annual Energy Outlook (AEO). The 2008 AEO had been prepared with an early-release scenario in 2007, but was revised to account for the changes that the EISA would have on primary energy consumption and the emission of greenhouse gases (GHG) associated with the use of fossil fuels. The EIA projected a reduction of 5.3 quadrillion BTUs in total energy consumption from 2008 to 2030 as a result of EISA, and a 7\% annual reduction in GHG emissions. The 2009 AEO did not specifically identify overall energy consumption reductions attributable to the EISA provisions, but it did predict strong growth in the use of biofuels of 3.3 percent per year, compared to an overall growth in energy use of only 0.5 percent annually. The EIA did attribute the projected increase in the biofuels component of the fuel supply to the EISA.

By some estimates, the reduction of GHG emissions must be reduced by far greater amounts in the coming years, especially as the provisions of EO13514 (see Section 2) begin to be implemented. Renewable energy is part of the solution to the reduction of GHG emissions as well as to help satisfy the nation's growing appetite for energy in a sustainable manner. The EIA has summarized the 
sources of energy and the expenditures of energy in the United States (see Figure 13). Renewable energy is currently only a small contributor to the overall supply.

Increased research activities at NREL in response to changes in the national policy are only one example of the interface of policy and renewable energy. In 2009, NREL continued to make advances in renewable energy technologies that will contribute to the growth of this segment of the overall energy economy.

\subsection{NREL Research Helping Meet Legislative Goals}

Since its origination as the Solar Energy Research Institute (SERI), NREL has been involved in the fundamental development of solar energy technologies. As a research institution, NREL ranks second among all U.S. laboratories in the number of energy-related publications and has the unique distinction of having published the number one cited article in the energy field (Contreras 1999).

\subsubsection{General Capabilities}

With the addition of the National Wind Technology Center (NWTC), the Alternative Fuels Users Facility (AFUF), and a number of related facilities and organizations, NREL has increased the portfolio of research activities to include wind, biofuels, and energy efficiency technologies for residential, commercial, and industrial applications. Recently, NREL has increased the level of activity in energy delivery and storage, including energy transmission and distribution, alternative fuels, and hydrogen delivery and storage. For example, NREL has developed a wind-to-hydrogen project at the NWTC to demonstrate the technologies of converting wind and solar energy into hydrogen through the electrolysis of water. In addition, the Hydrogen Test Facility began operations in 2007 where research is aimed at reducing the delivered costs of electrolytic hydrogen. Cost effective energy conversion and storage will greatly enhance the viability of renewable energy technologies, particularly those where energy production is intermittent, such as wind and solar.

\subsubsection{Biofuels}

The EISA established rigorous goals for developing biofuel substitutes for petroleum-based fuels used for transportation (except ocean-going vessels). The Renewable Fuels Standard has now been expanded to require the annual production of 36 billion gallons of renewable fuel in motor fuels by 2022. Of that, 21 billion gallons must be from advanced biofuels, which is defined as biofuel produced from feedstocks other than corn starch. The EISA mandates that advanced biofuels include cellulosic fuels and biomass-derived diesel substitutes, and further, that these fuels have at least 50\% less GHG emissions than petroleum fuels. NREL is well positioned to contribute to the development of biofuels technologies that will facilitate meeting these ambitious goals. The 2009 AEO predicts that the 2022 goal will not be met, but further predicts that the annual production of biofuels will significantly exceed the 36 billion gallon goal by 2030 .

In 2009, NREL initiated work aimed at establishing cyanobacteria as a genetic model for solar biodiesel production. This work focuses on a specific strain of cyanobacteria that has the potential to store large amounts of triacylglycerols, the lipid feedstock for biodiesel production. In support of the biodiesel from algae research effort, the greenhouse at the Field Test Laboratory Building was renovated in 2009 to allow for the installation of algal growth chambers. 


\subsection{NREL - Research to Reverse Climate Change}

The energy policy shift embodied by the EISA establishes rigorous goals to bring the nation to energy independence, but it also acknowledges the growing concern over climate change. The goals for reducing greenhouse gas emissions just begin to address the problem, however. In a 2007 report produced by the American Solar Energy Society entitled "Tackling Climate Change in the U. S.", research indicates that GHG emissions in the United States must be reduced by the equivalent of 1,100-1,300 million metrics tons of carbon per year (MtC/Yr) by 2030 to limit atmospheric carbon dioxide levels to between 450 and $500 \mathrm{ppm}$. The report goes on to say that this level of $\mathrm{CO}_{2}$ reduction can be achieved with a combination of energy efficiency improvements in the building, vehicles, and industrial sectors (57\%), and renewable energy installations (43\%).

Of the $43 \%$ reduction ( $516 \mathrm{MtC} / \mathrm{yr}$ ) projected to be achieved through the deployment of renewable energy technologies, a majority of the GHG reduction would come from wind energy (181 MtC/Yr). The additional reductions would be from concentrating solar power (CSP) (63), photovoltaics (63), biofuels (58), biomass, (75) and geothermal (83). A recent survey of the growth of the first generation of these technologies from 2002 through 2007 shows that the installed capacity for wind generation has had the greatest increase.

NREL is active in research in most of these areas, but particularly in wind, photovoltaics, and CSP.

\subsubsection{Wind}

NREL continues to advance wind energy technologies at the National Wind Technology Center. In 2009, the installed wind generation capacity at the NWTC was increased significantly. In August, the installation of a 1.5 megawatt General Electric wind turbine was completed, followed by the installation of a 2.3 megawatt Siemens unit. A number of research projects are associated with these two new installations, including a joint project to study the design and performance of wind turbine foundations.

\subsubsection{Concentrating Solar Power}

Concentrating solar power (CSP) technologies can be a major contributor to our nation's future need for new, clean sources of energy, particularly in the Western United States.

2009 will be remembered as a banner year for the CSP program when NREL won two R\&D 100 awards. The first was for a high-efficiency parabolic trough collector for utility-scale solar thermal power plants. The new trough design uses a weatherproof, high-reflectance polymer film which solves a number of problems that existing trough designs present. The NREL CSP program also won a 2009 R\&D 100 award for the Ultra-Accelerated Weathering System, which allows researchers to see the degradation caused by long term weathering without having to wait years or decades for results.

\subsubsection{Photovoltaics}

The development of technology to capture solar energy is at the core of research conducted at NREL. The laboratory has won numerous awards for its innovative work in producing ever more efficient photovoltaic (PV) configurations, including two prestigious R\&D 100 Awards in 2008, which received further recognition in 2009.

One of NREL's R\&D 100 awards recognized the IMM Solar Cell, a breakthrough in solar cell design and performance. The ultra-light, highly efficient solar cell represents a new class of solar cells with 
clear advantages in performance, engineering design, operation, and cost. In this new method of development the cell is grown upside down, allowing for greater absorption and use of sunlight. By turning the conventional approach to cells literally on its head, the result is an ultra-light and flexible cell that converts solar energy with record efficiency. Having already set a pair of world records for solar conversion efficiency when it was nominated, the cell has just set a third world record with a solar conversion rate exceeding $40 \%$.

The second R\&D 100 award spotlights a new technology for manufacturing Hybrid CIGS - thin film PV employing layers of copper indium gallium diselenide. NREL, in partnership with HelioVolt, developed a method where hybrid CIGS cells are manufactured in layers by using ink-jet and ultrasonic technology to precisely apply metal-organic inks in separate layers directly into common building materials like metal and glass. This simple approach could integrate enough flexible PV film into windows, roofing, and other structural components to turn entire buildings into small, selfsustaining power plants.

In 2009, Colorado Governor Bill Ritter recognized these accomplishments by presenting NREL with the Governor's Award for Research Impact in Renewable Energy.

\subsection{NREL and the Community}

During the course of operating a major national laboratory, events occur which may have an impact on the environment. The NREL site experienced one incident in 2009 that had minor environmental impacts but initiated several operational changes at the lab.

\subsubsection{Hexamethyldisilthiane Spill}

On May 1, 2009, a researcher in the Solar Energy Research Facility (SERF) broke a vial of hexamethyldisilthiane releasing the contents into a laboratory. While the work had been conducted in a hood, the vial fell out of the hood resulting in a release of the chemical into the ventilation system of the laboratory and, eventually, in both the SERF and the adjacent Science and Technology Facility (S\&TF). The event was attributed to the researcher using an inappropriate tool to open the glass vial, deviating from the approved operating procedure. During the evaluation following the incident, laboratory practices were reviewed and revised to prevent such events in the future and to provide accurate safety information in a timely manner.

Hexamethyldisilthiane is extremely odiferous, with the potential for harmful health effects, prompting emergency response personnel to recommend evacuating both buildings. Both internal and external response organizations were present for this incident and worked together to effectively control the situation. There was no release to the environment as a result of this event. 


\section{Environmental Management System}

NREL's Environmental Management System (EMS) provides effective environmental stewardship of its federally-owned sites and minimizes the environmental impacts of the lab activities. The laboratory's EMS efforts protect and enhance the vegetation, wildlife, and natural resources of the lab sites; comply with environmental requirements; and encourage continuous improvement in environmental protection.

NREL's Environmental Management System meets the requirements of the ISO14001 standard and was fully implemented prior to June 30, 2009, as required by DOE Order 450.1A, 4.d. (2), and was confirmed by DOE as meeting this requirement. In DOE's conformance letter dated June 26, 2009, DOE made this declaration based on the formal audit conducted on May 4-8, 2009 and that the appropriate NREL senior management and DOE Golden Field Office management have recognized and addressed the findings of the audit per the order.

For a full description of NREL's EMS elements, please see NREL Environmental Management System Description available at http://www.nrel.gov/eshq/pdfs/43419.pdf .

\subsection{Policy}

Environmental protection is a priority at NREL, as demonstrated by the laboratory's Environmental Protection Policy presented below.

NREL's EMS implements the laboratory's Environmental Protection Policy. It is a framework of policies, procedures, and programs integrated with normal management processes and combined with the environmentally sound daily work practices of the Environment, Health, and Safety (EHS) Office staff and personnel. Environmental protection must involve everyone at the lab to be effective. All activities conducted at NREL must comply with federal and state environmental laws and regulations, and DOE requirements.

As a DOE-owned facility, NREL is required by DOE Order 450.1A to implement its EMS as part of an ISM System. NREL's EMS meets this requirement while also incorporating the elements of ISO 14001, the international environmental management standard. In addition, the criteria of EO 13423, Strengthening Federal Environmental, Energy, and Transportation Management, are incorporated into the EMS. Policy 6-2: Environmental Protection, and supporting laboratory-level environmental programs and procedures that define the NREL EMS are coordinated and linked with Policy 2-1: Integrated Safety Management, Policy 2-7: Sustainable NREL, and the related supporting lab-level safety, health, and sustainability programs and procedures. 


\section{NREL Environmental Policy Statement}

NREL exemplifies sustainability by maximizing efficient use of resources, minimizing waste and pollution, and serving as a positive force in economic, environmental, and community responsibility. To this end, NREL is committed to:

Economic Viability. Managing laboratory fiscal resources efficiently to meet applicable regulations and effectively accomplishing the laboratory's mission, taking sustainability into consideration.

Environmental Stewardship. NREL is committed to sound environmental management that serves as an example to others and supports the laboratory's mission to protect natural resources through research, development, and deployment of renewable energy and energy efficiency technologies. To this end, NREL is committed to:

- Pollution Prevention. Incorporating pollution prevention practices in research and support activities

- Continuous Improvement. Continuously improving the effectiveness of NREL's environmental management system (EMS)

- Campus. Managing the impact on the environment caused by the placement and general design of NREL structures; maintaining, protecting, and restoring natural and landscaped environments to sustain natural and native ecological systems, both on and adjacent to NREL campuses

- Water. Reducing water consumption and managing water discharges from the site

- Electricity/Natural Gas. Reducing energy use in building designs and operations, within available funds; using cost effective renewable energy sources for remaining energy needs; and purchasing power generated by renewable energy sources

- Transportation. Reducing the impact of local NREL travel on the environment; reducing the use of fossilbased gasoline/diesel fuel for NREL onsite and local operations through the use of alternative fuel vehicles or hybrids; and increasing the use of video and teleconferencing to reduce the environmental impacts of air travel

- Materials. Reducing the use of materials and the creation of waste by reducing, reusing, and recycling materials needed for laboratory operations; increasing the purchase and use of environmentally sensitive products and products with recycled content

- Environmental Management. Providing an environment that promotes efficiency, effectiveness, and sustainability, and encourages the creativity and personal motivation required for excellence in scientific, engineering, technology development, and support functions

- Education/Communication. Informing and providing outreach to workers about sustainability activities, including a method for interaction and feedback; educating workers about participating and contributing to sustainable activities; informing workers and the public about NREL's environmental performance, including a method for interaction and feedback

- Compliance with Requirements. Complying with applicable federal, state, and other environmental requirements and exceeding those requirements, when feasible, by implementing environmental best management practices.

Public Responsibility. Working with local stakeholders to identify and implement collaborative projects to improve sustainability of the local community; educating others about sustainability through a variety of outreach mechanisms. 


\subsubsection{Significant Aspects}

In 2009, staff reviewed the organization's potential impacts to the environment and reconfirmed without changes its determination of "significant environmental aspects":

- Emissions to air

- Surface water releases

- Wastewater releases

- Accidental releases

- Solid waste generation and management

- Hazardous waste generation and management

- Source reduction, reuse, or recycling

- Purchase of Environmentally Preferable Products (EPP)

- Energy Use

- On-site energy generation using renewable sources, and use of energy efficiency technologies

- Water use

- Other natural resources and raw materials use

- Impacts to land, including restoration

- Impacts to wildlife or vegetation, including habitat impacts and preservation

- Impacts to groundwater

- Impacts on communities (e.g. traffic noise, vibration, odor, visual appearance, etc.), including benefits.

Each of these aspects is addressed by the management system through elements such as operational controls and objectives and targets. The 2009 objectives are described in Section 4.2 below.

\subsubsection{EMS Effectiveness - Benefits to the Environment and NREL}

NREL's management system has been in place since the 1990s and has seen numerous benefits over the years. Here is a summary of some of those benefits.

Reduced risk. Safe Operating Procedures are developed based on a hazard identification and risk analysis process which incorporates environmental risk assessment.

Cost savings. Any avoided impact represents cost savings, specifically in the event of spills and incidents.

Environmental awareness. Staff are made aware of the potential environmental impacts from their work activities through a variety of mechanisms including broad communications in the NREL Now newsletter and postings on the NREL intranet, as well as through activity specific trainings and procedures.

Empowered individuals. Staff are empowered to reduce NREL's environmental footprint including participation in programs and events for recycling single-stream materials, batteries, electronic equipment, and shredded paper, as well as a pilot composting program. Staff at the new Research Support Facility are able to support a new ultra high efficiency energy goal for the building by reducing their energy use in the office. Researchers are participating in a self-inspection program for hazardous wastes generated in their own labs. Increased responsibility and awareness of lab wastes will likely reduce the amount of wastes generated. 
Organizational culture and operations. NREL strives to maintain high level of awareness in the laboratory around safety, health, and environmental issues. This is accomplished through a variety of means, including regular communications from executive management, as well as at the ground level through each interaction of EHS staff with lab staff in trainings, inspections, risk assessments, and daily interactions.

Real Property Asset management. NREL strives to achieve LEED Gold ratings for all new buildings and major renovations.

Community relations. NREL seeks to improve community relations by responding to and tracking all community input through phone calls, email, community meetings, and the NEPA process. NREL takes proactive measures to engage the community with public tours, newsletters, and mailings to neighborhoods surrounding its facilities.

Mission. NREL's EMS supports the organization's overall mission and improves effectiveness by systematically addressing environmental opportunities and risks, ensuring compliance with regulations, and going beyond mere compliance.

Cooperative conservation. NREL regularly works with community stakeholders to improve the community. For example, with the growth of the South Table Mountain campus, NREL implemented a Traffic Mitigation Plan to reduce forecasted impacts of increased traffic to the facility.

While NREL benefits as an organization from each of the efforts highlighted here, the larger benefit is in reduced impacts to the quality of the air, water, land, and to the flora and fauna that share the campus and community.

\subsubsection{Notable 2009 Activities}

\subsubsection{Federal Electronics Challenge}

In 2009, NREL achieved the Gold-level Federal Electronics Challenge (FEC) Award. FEC is a partnership program between the Office of the Federal Environmental Executive and the EPA. The FEC recognizes federal facilities that voluntarily:

- Purchase greener electronic products

- Reduce impacts of electronic products during use

- Manage obsolete electronics in an environmentally safe way.

To learn more about the award, please see the NREL FEC poster summary (PDF 4 MB). Learn more about this voluntary program at the Federal Electronics Challenge Web site at http://www.federalelectronicschallenge.net/.

\subsubsection{External EMS Audit}

In May of 2009, NREL completed an external audit of its management system. The audit identified non-conformities with the ISO14001 requirements for which corrective and preventive action plans were developed to address the issues identified. These issues ranged from lack of awareness of the environmental policy, to references in system documents, to obsolete or out of date documents. To date, several action plans have been completed while other longer term corrective action plans are still in progress. 


\subsubsection{Colorado Environmental Leadership Program}

NREL continued progress toward environmental performance commitments made as a Gold-level Leader in Colorado's Environmental Leadership Program (ELP). The Colorado ELP is the voluntary partnership between Colorado Department of Public Health and Environment (CDPHE) and participating private and public Colorado facilities, recognizing environmental leadership and performance.

In early 2004, NREL was the first laboratory accepted into the Colorado ELP as a Gold-level leader and has maintained this leadership level ever since. NREL sets voluntary three-year environmental performance goals as a component of ELP membership in an effort to further enhance operations and performance at the laboratory. The current goals were established in 2007 and are described in detail in Section 4.2.2.1 below.

The CDPHE ELP recognizes facilities that voluntarily:

- Exceed regulatory requirements

- Implement EMSs (which focus on incorporating environmental considerations into normal management processes and improving internal environmental management effectiveness)

- Work closely with their communities

- Set three-year goals focusing on measurable results.

Learn more about this voluntary program at the Colorado Department of Public Health and Environment Web site at http://www.cdphe.state.co.us/el/elp/index.html.

\subsubsection{Public Outreach}

NREL works with community organizations to implement laboratory sustainability practices and expand its clean energy technology research and development. Laboratory sustainability has been implemented through community meetings, laboratory tours, and community newsletters garnering community support for implementing goals. NREL's demonstration of clean work practices improves the local quality of life and sets an example for future community development.

Throughout 2009, NREL employees gave their time, money, and energy to help the community. They were backed by a commitment from the Alliance for Sustainable Energy, LLC to provide financial support that allowed NREL to work in community organizations, support local economic development efforts, and educate teachers, students, and consumers about renewable energy and energy efficiency.

NREL's engagement with statewide business, government, and community leaders was at an all-time high this year. Economic and community outreach activities ranged from forums for the Metro Mayors' Caucus to visits by Colorado's Congressional Delegation and tours of NREL by economic development organizations, workforce boards, and municipal planning committees.

The Visitors Center is central to NREL's interaction with the public. Not only is it the "front door" to the more than 18,000 visitors to the laboratory each year, it is an educational resource for consumers, teachers, and students. The addition of the Science on a Sphere exhibit attracted many new visitors with its 3-dimensional programs about energy's impact on the world. Monthly consumer programs on hot new research topics and simple how-to instructional courses are regularly attended by hundreds of people.

\subsection{Performance Indicators and Progress}




\subsubsection{Environmental Objectives and Progress toward Goals}

Each fiscal year, in collaboration with DOE-GO, NREL develops environmental performance objectives for the upcoming year as part of the lab's One-Year Plan. The FY 2009 goal was "to demonstrate that ES\&H is a priority; that processes and practices are in place to effectively identify and manage risks to protect NREL workers, the local community, and the environment; and that the laboratory complies with all applicable DOE requirements, regulation, laws, and laboratory policies and procedures."

For FY 2009, the environmental objectives were:

- A safe and healthful workplace based on identified and managed risks

- Further ISM through the development of improved management systems

- Transform environmental excellence to a sustainability strategy.

NREL successfully completed the One-Year Plan objectives. Some noteworthy achievements in FY 2009 include:

- Supported lab growth by implementing an Advanced EHS Orientation course, which allows workers to spend time (2-3 weeks) in their work areas then return for advanced safety training on chemical safety, pressure safety, lockout tagout, electrical safety, and hazardous waste management

- Supported the installation of a solar array-worked with SunEdision to control fall hazards on the roof top of the S\&TF. Relocated prairie dogs impacted by the NWTC array

- Identified hazards associated with accumulated wood dust and issues associated with smoke emissions and opacity at the RFHP. Work with Ameresco to develop and implement feasible controls

- Traffic mitigation plan implemented to alleviate forecasted traffic congestion from the RSF and ESIF population growth at the South Table Mesa site

- NEPA review completed for the Supplement II to Site-wide Environmental AssessmentSouth Table Mountain Complex

- Sustainability Program Director position established, elevating leadership in sustainable operations consistent with NREL's values and mission.

\subsubsection{State of Colorado ELP Commitments (2007-2010)}

\subsubsection{Current Commitments}

The following multi-year commitments were made to CDPHE's ELP program for 2007 through 2010.

\section{Campus Planning}

- NREL actively "walks the talk," having made a tremendous start by achieving Leadership in Energy and Environmental Design (LEED) Platinum designation at the Science and Technology Facility (S\&TF) in March 2007. NREL plans to attain LEED Gold or better for all future building design and construction. For planning purposes, NREL developed a Grand Buildout Plan, including design of the 222,000 gross square foot (gsf) Research Support Facility (RSF). NREL's STM buildout plan calls for growing from 400,000 gsf to 1,100,000 gsf, and from 450 occupants to 2,700 occupants. As mentioned in Section 1, the RSF, like the $\mathrm{S} \& \mathrm{TF}$, is on track to be LEED Platinum 
- NREL committed to exceed the 3\% FY 2007 GHG reduction required by EO 13423. This will be completed through the deployment of energy efficient and renewable energy technologies on site at NREL, and through the purchase of renewable energy certificates

- NREL's goal was to apply for acceptance into the Federal Electronics Challenge (FEC), and complete 19 projects in order to apply for the 2007 FEC Silver-level Award given jointly by the Office of the Federal Environmental Executive and the U.S. EPA.

\section{Results}

NREL has successfully achieved its ELP commitments for 2009.

- Sustainable buildings

- All laboratory new construction complies with the Guiding Principles for Federal Leadership in High Performance and Sustainable Building. As of FY 2009, 13\% of NREL's existing building inventory incorporates the sustainable practices in the Guiding Principles. With the completion of the RSF I in FY 2010, NREL will have exceeded its FY 2015 15\% goal

- $\mathrm{GHG}$

- NREL easily exceeded the 3\% per year GHG reduction goal required by the federal Executive Order 13423, Strengthening Federal Environmental, Energy and Transportation Management. In addition, NREL successfully achieved its Climate Leaders goal of reducing its total GHG emissions by 75\% from FY 2005 to FY 2009. NREL has exceeded this goal to totally offset the laboratory's $\mathrm{CO}_{2}$ footprint with energy retrofits, onsite renewable energy projects, minimum Gold level ratings of the Leadership in Energy and Environmental Design (LEED) standards for new construction and "green power" purchases of RECs and carbon credits

- Electronics

○ NREL was awarded the 2009 EPA Federal Electronics Challenge Gold Level Award, recognizing NREL's efforts toward environmentally sound management of electronic waste management/recycling and sustainable electronic purchasing.

\subsubsection{Future Commitments}

NREL has submitted the following commitments for 2011 through 2013:

- NREL will demonstrate environmental leadership by attaining ISO 14001 Certification for its environmental management system

- Implement a Pollution Prevention Initiative Program to identify P2 opportunities and provide resources and funding to achieve desired results

- Increase on-site renewable energy generation by $100 \%$ to approximately $4 \mathrm{MW}$

- NREL will participate in the Sustainable "SITES" Initiative Pilot Program and obtain Pilot Certification.

\subsubsection{Environmental Objectives}

The environmental objectives developed by NREL in collaboration with DOE-GO are to meet the Environment, Safety, and Health (ES\&H) Management goal stated in the Performance Evaluation Measurement Plan. The FY 2010 goal is "to demonstrate that ES\&H is a priority; that processes and practices are in place to effectively identify and manage risks to protect NREL workers, the local community, and the environment; and that the laboratory complies with all applicable DOE requirements, regulation, laws, and laboratory policies and procedures." 
For FY 2010, the environmental objectives are:

- A safe and healthful workplace based on identified and managed risks

- Further ISM through the development of improved management systems

- Transform environmental excellence to a sustainability strategy.

Progress toward the 2010 objectives will be reported in the NREL 2010 Environmental Performance Report.

\subsection{Assessment and Improvement}

Periodic assessment and management review of NREL's EMS and its components provide verification that the EMS continues to be an effective tool to achieve and maintain compliance with regulatory and legal requirements, meet the established environmental goals of the laboratory, and maintain management support for NREL's environmental goals. Assessments and management reviews also provide for continuous improvement of the EMS.

There are three different types of assessments performed to evaluate the functionality of the EMS at NREL: EMS assessments, periodic compliance assessments, and third-party assessments.

A team of NREL staff generally performs periodic assessments of NREL's EMS internally. The scope of the assessments includes both the management of significant environmental aspects (areas where NREL activities have the potential for environmental effects, either positive or negative) and policy implementation. The team evaluates the EMS based on an appropriate set of criteria, such as ISO 14000 standards, DOE Order requirements, Colorado Environmental Leadership Program standards, or other applicable environmental management standards.

Periodic compliance assessments are conducted of individual environmental programs to verify that each program, as written, meets all applicable legislative and regulatory requirements and that the program is implemented as intended (see Section 5.0 for examples). Improvements are developed and implemented as necessary, based on the results of each assessment.

In addition to compliance assessments of individual NREL environmental programs, NREL has management system review processes in place for regular reviews and updates of the set of policies, lab-level programs, and task-specific procedures, including EMS policies and programs. NREL reviews its EHS policies and laboratory-level procedures as needed, but at least every five years, making revisions as necessary. All SOPs are reviewed on an annual basis and are revised as necessary to help ensure the required controls are appropriate for the hazards present. Environmental hazards and controls are specifically called out in each SOP.

Periodically, external third-party assessments may be conducted by technical experts for specific components of NREL's environmental programs or for the EMS as a whole. These assessments are conducted on an as-needed basis. A third-party, external audit of the EMS was conducted in 2009 and similar audits are planned for every three years, as required by DOE Order 450.1A.

\subsubsection{Assessment Activities}

In May of 2009, NREL received an independent assessment of its EMS to measure the system's sufficiency and effectiveness. 
The assessment was based on the ISO 14001:2004 standard, the NREL EMS description, and any related process documents such as lab-level and desk procedures. The assessment consisted of documentation review, site visits, and interviews with EMS staff and other workers involved with or affected by the EMS. Several recommendations for improvement were identified. A number of corrective and preventive actions were completed in 2009 and several longer term fixes are underway to address all remaining issues identified.

Annual EMS internal assessments will continue to monitor performance of the system. In addition, NREL is seeking ISO14001 3rd party certification for its EMS in 2011. For this, an external assessment will take place initially and will reoccur on a regular basis to maintain certification.

\subsection{Sustainability and the Environmental Management System}

NREL's mission has always focused on a sustainable energy future for our nation and the world. Sustainability is defined as meeting the needs of the present without compromising the ability of future generations to meet their needs, and involves the simultaneous and balanced pursuit of economic viability, environmental stewardship, and public responsibility.

The Sustainable NREL program was created to realize the vision of greater sustainability in NREL operations. It is an interdisciplinary initiative involving staff from numerous NREL centers and offices with the goals of maximizing efficient use of resources; minimizing waste and pollution; and serving as a positive force in economic, environmental, and public responsibility. Elements of the environmental stewardship component of Sustainable NREL include:

- Renewable energy solutions

- Sustainable green buildings, campus planning, and transportation

- Water, electricity, and natural gas use reduction

- Greenhouse gas emission reductions

- Reduce, reuse, and recycle materials use

- Public responsibility/community outreach

- Environmental management.

Sustainable NREL carries out the laboratory's commitments to, among other things, reducing energy use in its building operations, designing energy efficient and environmentally sensitive new buildings, reducing water consumption, decreasing GHG emissions, minimizing the impact of NREL local and air travel on the environment, using less fossil-based fuel for local operations, incorporating renewable energy technologies into its on-site STM and NWTC operations, and creating less waste by reducing, reusing, and recycling materials for laboratory operations.

In addition, the EMS supports Sustainable NREL's goals by focusing on protecting the natural and cultural resources on and around NREL sites by:

- Reviewing NREL's potential for environmental impacts through emissions, discharges, waste generation, purchases, and land use

- Conducting required permitting activities

- Managing site natural resources for protection and preservation of their natural character to the extent possible, while still fulfilling NREL's mission

- Managing site cultural resources for documenting resources of significance and minimizing disturbances whenever possible

- Recommending and coordinating measures to minimize any potential impacts NREL's activities have on the environment. 


\subsubsection{Results}

The following information is excerpted from Sustainable NREL's 2009 Sustainability Report. Please see www.nrel.gov/sustainable nrel for the full report.

NREL has accepted DOE's challenge to provide environmental stewardship leadership in the DOE complex by achieving or exceeding DOE Order 430.2B. By actively working to maintain a sustainable environment in our own workplace the laboratory demonstrates its commitment to minimal use of resources and balance environmental, economic, and human impacts.

\subsubsection{Energy Efficiency}

\section{Energy Use Reduction Goal}

DOE Order 430.2B: Beginning in FY 2006 improve energy efficiency through reduction of energy use intensity by $3 \%$ annually through the end of FY 2015 or 30\% by the end of FY 2015 as compared to the baseline energy use in FY 2003.

Progress: In FY 2009 NREL's energy use intensity decreased 7\% from our FY 2003 baseline. This did not include the allowable Renewable Energy Credit (REC) reductions. NREL will exceed the FY 2015 goal through the significant additions of highly energy efficient new buildings (exclusive of the use of RECs).

Energy use reduction on NREL's campus is focused on the design and construction of highly energyefficient new buildings (see the section on Sustainable Green Buildings). Cost-effective energyefficiency retrofit opportunities have, for all practical purposes, been implemented. Specifically, NREL expects to exceed the required FY 2015 energy use intensity reduction goal of $30 \%$ by significantly exceeding the energy use requirements of the federal energy efficiency new construction requirements.

\subsubsection{Renewable Energy}

\section{Renewable Energy Generation and Use Goals}

DOE Order 430.2B: Use of renewable energy shall be 3\% for each year from FY 2008 through FY 2009; 5\% from FY 2010 through FY 2012; and 7.5\% from FY 2013 forward. At least half of the statutorily required renewable energy consumed each fiscal year shall come from "new" (post January 1, 1999) renewable sources.

Progress: FY 2009 renewable energy use was 100\% of annual electric consumption achieved primarily through the utilization of on-site renewable energy projects and the purchase of RECs. One hundred percent of the renewable energy use was from "new" renewable energy resources. These results significantly exceed the FY 2013 renewable energy electric generation and use goals.

NREL's Mesa Top PV system located in Golden, Colorado has a $750 \mathrm{~kW}$ capacity and generated 1015 MWh of electricity from January 1, 2009 to September 30, 2009. This electrical production represents 7\% of NREL's STM site electrical consumption. This system was installed under Power Purchase Agreements (PPAs) with a third-party developer, and one will be purchased utilizing appropriations. The Mesa Top PV system was the first DOE PPA agreement. Additional on-site renewable energy projects are in the process of being completed. PV is planned for all new major buildings. 
A 1.5 MW General Electric wind turbine, purchased by DOE, was installed at the NWTC on August 21, 2009; it began operation in October 2009. The estimated production from the DOE/GE turbine is 1,600,000 kWh/year (enough to serve 142 homes). In FY 2010 NREL plans to sell the power produced by this R\&D turbine to the grid through a "sale of power" agreement with the local utility. The Siemens Turbine 2.3 MW, installed at the NWTC on September, 24, 2009, has an estimated production of 2,800,000 kWh/year (enough to serve 249 homes). It began operation in October 2009.

The thermal output of the Renewable Fuel Heating Plant (RFHP) positions NREL to significantly exceed the DOE Order 430.2B renewable energy thermal generation goal $(7.5 \%$ of annual thermal energy use by FY 2013). The RFHP was installed through an energy savings performance contract (ESPC) and has been in full operation. Thus far there has been an 11\% savings of natural gas.

In support of our mission and this DOE mandate, we continue to proactively pursue sustainability in all of our operations-incorporating on-site renewable energy projects as described in the following table.

Table 2. On-site Renewable Energy Projects

\begin{tabular}{|l|l|l|l|}
\hline \multicolumn{1}{|c|}{ Site } & \multicolumn{1}{|c|}{ Rating } & \multicolumn{1}{c|}{ Annual Energy } & \multicolumn{1}{c|}{ Operational Year } \\
\hline South Table Mesa Top & $720 \mathrm{~kW}$ & $1,200,000 \mathrm{kWh}$ & $12 / 2008$ \\
\hline $\begin{array}{l}\text { Science and Technology } \\
\text { Facility (S\&TF) }\end{array}$ & $94 \mathrm{~kW}$ & $134,813 \mathrm{kWh}$ & $10 / 2009^{*}$ \\
\hline $\begin{array}{l}\text { National Wind } \\
\text { Technology Center } \\
\text { (NWTC) }\end{array}$ & $1,083 \mathrm{~kW}$ & $1,913,661 \mathrm{kWh}$ & $10 / 2009^{*}$ \\
\hline $\begin{array}{l}\text { Research Support } \\
\text { Facility1(RSF I) }\end{array}$ & $741 \mathrm{~kW}$ & $976,009 \mathrm{kWh}$ & $6 / 2010^{*}$ \\
\hline RSF1Parking Garage & $630 \mathrm{~kW}$ & $829,710 \mathrm{kWh}$ & $6 / 2010^{*}$ \\
\hline Totals & $\mathbf{3 , 2 6 8 ~ k W}$ & $\mathbf{5 , 0 5 4 , 1 9 3 ~ k W h}$ & \\
\hline
\end{tabular}

\subsubsection{Environmental Footprint}

NREL began tracking its $\mathrm{CO}_{2}$ emissions in FY 2003. NREL quantifies its "carbon footprint" by including emission sources beyond the laboratory's boundary, such as laboratory leased space, air travel, and the commuting of staff members to and from work. Sources with negligible emissions such as fleet vehicle emissions, solid waste disposal, and water (associated electricity or natural gas consumed) are not included in the graph.

Table 3. $\mathrm{CO}_{2}$ Emissions in FY09

\begin{tabular}{|l|r|}
\hline \multicolumn{1}{|c|}{ SOURCE } & \multicolumn{1}{c|}{ Kg CO$_{\mathbf{2}}$ Eq. } \\
\hline Electricity & $19,306,657$ \\
\hline Natural Gas & $3,807,131$ \\
\hline Commuter Vehicle Emissions & $5,328,288$ \\
\hline Domestic Air Travel Emissions & $2,706,567$ \\
\hline International Air Travel Emissions & 707,823 \\
\hline Fleet Vehicle Emissions & 249,893 \\
\hline
\end{tabular}




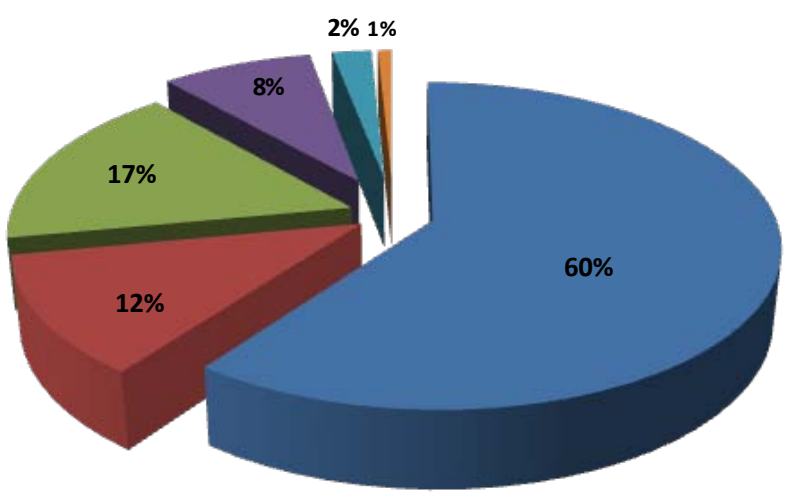

Electricity

Natural Gas

Commuter Vehicle Emissions

- Domestic Air Travel Emissions

International Air Travel Emissions

Fleet Vehicle Emissions

Figure 9. $\mathrm{FYO9} \mathrm{CO}_{2}$ emissions breakdown

The quantification of this footprint provides a metric which allows the laboratory to:

- Take into account the carbon implications of its investment decisions

- Measure progress towards achieving carbon reduction goals

- Benchmark performance

- Take responsibility for its actions.

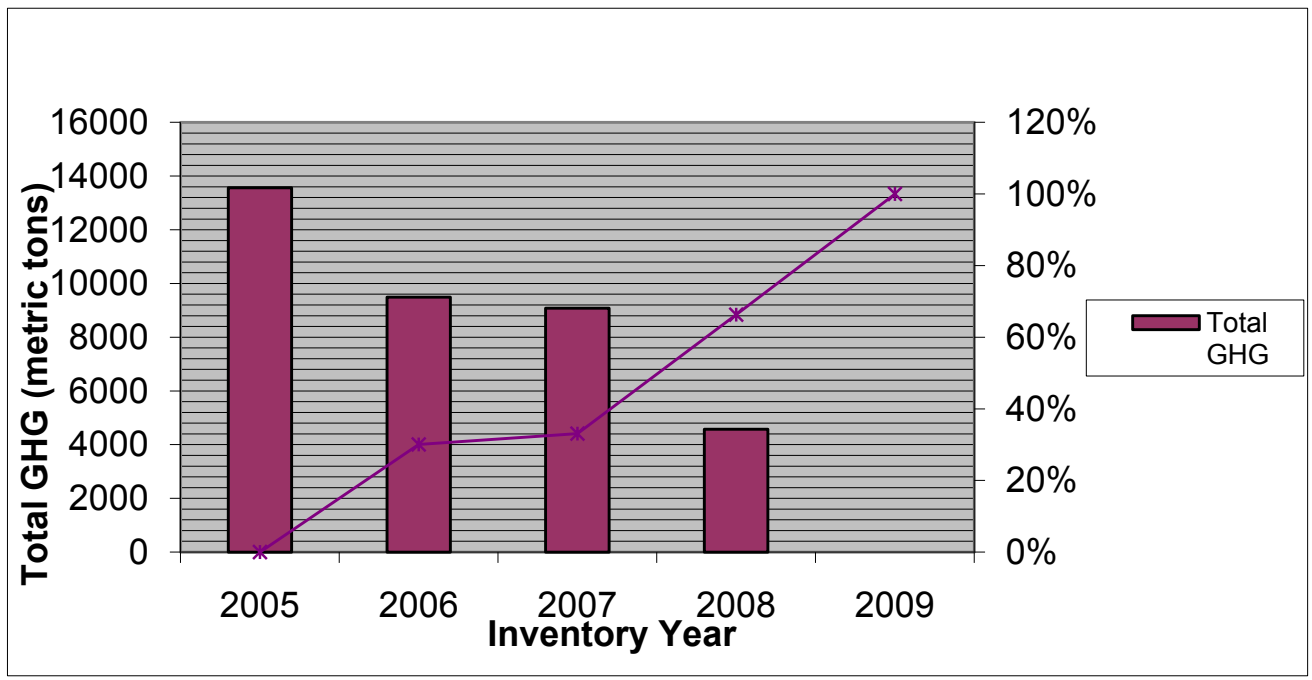

Figure 10. Climate Leaders Program, NREL total GHG emissions 


\subsubsection{Greenhouse Gas Reduction}

\section{Greenhouse Gas (GHG) Reduction Goals}

DOE Order 430.2B: Reduce GHG emissions by 3\% annually, or 30\% by the end of FY 2015, relative to GHG emissions in FY 2003.

NREL Goals: NREL will achieve "carbon neutrality" annually. NREL has pledged through the Environmental Protection Agency (EPA) Climate Leaders Program (CLP) to reduce its total U.S. GHG emissions by $75 \%$ from 2005 to 2009 .

Progress: In conjunction with energy use reduction performance, NREL is exceeding the DOE GHG reduction goals. NREL has met its FY 2009 EPA Climate Leaders GHG reduction goal.

New federal GHG reduction requirements are expected to be mandated as soon as 2010 . These mandates will focus on GHG emission measurement and reduction and utilize these reductions as its primary metric.

NREL is well positioned to provide leadership in this area, having established GHG emission inventory with reduction goals since FY 2000 through the EPA CLP. NREL met its first goal in FY 2005 reducing its GHG emissions by 10\% from the FY 2000 baseline. The laboratory set a second CLP goal of reducing its total GHG emissions by 75\% from FY 2005 to FY 2009. NREL has exceeded this goal to totally offset the laboratory's $\mathrm{CO}_{2}$ footprint with energy retrofits, onsite renewable energy projects, minimum Gold level ratings of the Leadership in Energy and Environmental Design (LEED) standards for new construction and "green power" purchases of RECs and carbon credits.

\subsubsection{Campus - Sustainable Green Buildings}

\section{Sustainable Design/High Performance Buildings Goals}

DOE Order 430.2B: New construction and major renovations shall comply with the Guiding Principles for Federal Leadership in High Performance and Sustainable Building (Guiding Principles). Fifteen percent of the existing building inventory as of the end of FY 2015 will incorporate the sustainable practices in the Guiding Principles. DOE sites will achieve a LEED Gold rating on all new buildings.

Progress:_All laboratory new construction complies with the Guiding Principles. As of FY 2009, $13 \%$ of NREL's existing building inventory incorporates the sustainable practices in the Guiding Principles. With the completion of the RSF in FY 2010, NREL will significantly exceed the FY 2015 15\% goal.

The first priority of the NREL campus energy strategy is to invest in site design and building development to maximize energy efficiency with appropriate building orientation and mass. This strategy takes advantage of passive solar design for heating, cooling, and natural lighting in all new building construction. Low-energy design strategies in office buildings focus primarily on reducing energy for lighting and cooling. Strategies in laboratories focus on reducing the energy needed to meet ventilation requirements. 
NREL's new major building, the RSF, is a 220,000 sq. $\mathrm{ft}$. office building scheduled for occupancy in June 2010. The RSF is a design-build project with a conservative energy budget of $32,000 \mathrm{Btu} / \mathrm{sq}$. $\mathrm{ft}$. The RSF is also being designed as a highly energy-efficient building at the LEED Platinum level.

Increased demand for renewable energy and energy efficiency technologies requires critical laboratory space and partnering facilities. Attributes of the planned space include energy efficiency, carbon neutrality, and LEED Platinum or Gold certification.

In addition, NREL manages the impact on the environment caused by the placement and general design of NREL structures-maintaining, protecting, and restoring natural and landscaped environments to sustain natural and native ecological systems, both on and adjacent to NREL campuses.

\subsubsection{Transportation}

\section{Petroleum and Alternative Fuel Use Goals}

DOE Order 430.2B: Reduce total fleet petroleum product consumption by $2 \%$ annually through the end of FY 2015 as compared to the FY 2005 baseline.

Increase the total fleet fuel consumption that is nonpetroleum-based by $10 \%$ annually.

Progress: NREL made negative progress in this area. See narrative below.

\subsubsection{Alternative-Fuel Vehicles and Bio-Based Fuels}

NREL's fleet of vehicles currently consists of one diesel commercial leased vehicle and 46 GSA vehicles. Thirty-six of the fleet use alternative fuels, three use diesel, and seven use unleaded gasoline.

In FY 2009, NREL's fleet consumption increased significantly. The use of E85 fuel increased 34\% due to (but not limited to) several factors.

- E85 fuel was not made available at the nearest E85 station (within 5 miles or 15 minutes)

- NREL's on site FAST CNG (compressed natural gas) station has been inoperable since April 2009

- Local mileage increased

- The alternative fuel vehicles used for snow removal were unable to fuel with alternative fuel due to fuel unavailability.

- $\quad$ NREL replaced two GSA ${ }^{1}$ CNG dedicated 15-passenger vans with two GSA diesel buses to assist in shuttling NREL's employees on site. NREL's shuttles are increasingly used to transport employees to and from local bus stops and for tours, visitors, etc. Fewer employees are using their personal vehicles onsite.

- $\quad$ NREL replaced one GSA Bi-Fuel CNG pickup truck with a C4500 unleaded box truck to assist NREL's Shipping and Receiving (S\&R) Department with their deliveries to include (but not limited to) gases, chemicals, large research equipment, etc. The smaller vehicle did not meet the requirements which impacted S\&R's mission.

\footnotetext{
${ }^{1}$ The GSA vehicles replaced were determined by GSA's replacement criteria i.e.: age, mileage, or the combination of both. The request to increase the size of the vehicle(s) and the type of fuel was approved by NREL and DOE Golden Field Office. This was necessary due to the increase in FTEs in FY 2009 and the fact that staff is located in several new leased facilities spread out through the Denver West Office park and STM campus.
} 


\subsubsection{Traffic Management}

To help ease traffic concerns, address planned parking management, and to decrease the reliance on single occupant vehicle trips, NREL developed a transportation program to manage traffic at the STM site.

In 2007, a team of consultants, Felsburg, Holt, and Ullevig and Urban Trans Consultants, completed the Traffic Impact Analysis that became the basis for a Mitigation Action Plan (MAP) required to allow several projects to proceed on the STM campus (the MAP is also discussed in Section 5.15, below). The analysis predicted that relocating approximately 800 employees to the Research Support Facility, combined with growth in the employee population would result in an increase of daily trips to the STM from 1934 to 5530 in 2010 . Mitigation actions were identified that would reduce this impact, with a goal of decreasing peak hour trips by $24 \%$.

The specific recommendations included in the plan address internal policies and programs, trip linkages, transit accessibility, parking management, and on-site transportation demand management strategies all of which enable NREL to address traffic and parking objectives.

The MAP will be implemented in three phases:

1. Startup (2008-2010).

2. Occupancy, which will begin when employees at Denver West Office Park begin to relocate to the STM site.

3. Buildout of the STM site.

A summary of the mitigation strategies is present in Table 4:

Table 4. Mitigation Strategies

\begin{tabular}{|c|c|c|c|c|}
\hline \multirow{2}{*}{$\begin{array}{l}\text { Traffic Mitigation } \\
\text { Strategy Categories }\end{array}$} & \multirow[b]{2}{*}{ Recommendations } & \multicolumn{3}{|c|}{ Phases } \\
\hline & & Startup & Occupancy & Build-out \\
\hline \multirow[t]{9}{*}{ Program Management } & $\begin{array}{l}\text { Designate Transportation Program } \\
\text { Coordinator }\end{array}$ & $\mathrm{x}$ & & \\
\hline & Distribute information and resources & $\mathrm{x}$ & $\mathrm{x}$ & $\mathrm{x}$ \\
\hline & Promote Regional Programs/Events & $\mathrm{x}$ & $\mathrm{x}$ & $\mathrm{x}$ \\
\hline & Develop Marketing Materials & $\mathrm{x}$ & $\mathrm{x}$ & $\mathrm{X}$ \\
\hline & Facilitate Carpool Ridematching & & $\mathrm{x}$ & $\mathrm{X}$ \\
\hline & Incentive Program Administration & & $\mathrm{x}$ & $\mathrm{x}$ \\
\hline & Shuttle Operations Management & & $\mathrm{X}$ & $\mathrm{X}$ \\
\hline & Parking Program Administration & & $\mathrm{x}$ & $\mathrm{x}$ \\
\hline & Program Evaluation and Monitoring & & $\mathrm{x}$ & $\mathrm{x}$ \\
\hline \multirow[t]{2}{*}{ Flextime } & Flextime Program Policy Planning & $\mathrm{x}$ & & \\
\hline & Implement Flexible Work Schedules & & $\mathrm{x}$ & $\mathrm{x}$ \\
\hline \multirow[t]{2}{*}{ Telework } & Telework Program Policy Planning & $\mathrm{x}$ & & \\
\hline & Telework Program Implementation & & $\mathrm{x}$ & $\mathrm{x}$ \\
\hline \multirow[t]{2}{*}{ Shuttles } & Prepare Shuttle Service Plan & $\mathrm{x}$ & & \\
\hline & $\begin{array}{l}\text { Implement Increased Shuttle } \\
\text { Service }\end{array}$ & & $\mathrm{x}$ & $\mathrm{x}$ \\
\hline \multirow[t]{2}{*}{ Carpool/Nanpool } & Implement Carpool Ridematching & & $\mathrm{x}$ & $\mathrm{x}$ \\
\hline & Establish vanpools & & $\mathrm{X}$ & $\mathrm{X}$ \\
\hline Facilities/Amenities & $\begin{array}{l}\text { Implement Site Facilities/Amenities } \\
\text { (Sidewalks, Bike Racks, etc.) }\end{array}$ & & $\mathrm{x}$ & $\mathrm{x}$ \\
\hline \multirow[t]{2}{*}{ Incentives } & Continue RTD Eco Pass Program & $x$ & $\mathrm{x}$ & $\mathrm{x}$ \\
\hline & Implement Incentive Program & & $\mathrm{x}$ & $\mathrm{x}$ \\
\hline \multirow[t]{3}{*}{ Parking Management } & Develop Parking Management Plan & $x$ & & \\
\hline & Implement Preferential Parking & & $\mathrm{x}$ & $\mathrm{x}$ \\
\hline & Parking Program Implementation & & $\mathrm{x}$ & $\mathrm{x}$ \\
\hline
\end{tabular}


In 2009, several key mitigation measures were implemented, including transit subsidies, telecommuting and flextime, and hiring a Transportation Program Coordinator to ensure compliance with the MAP. Some initial results from these efforts are reported below.

\section{Alternative modes of commuting}

- Free Eco Passes to use the Regional Transportation District (RTD) public transportationunlimited RTD regional, express, local, light rail, and Call-n-Ride services.

- Alternative-fuel shuttle vehicles that reduce miles traveled at its STM and Denver West sites in Golden, Colorado.

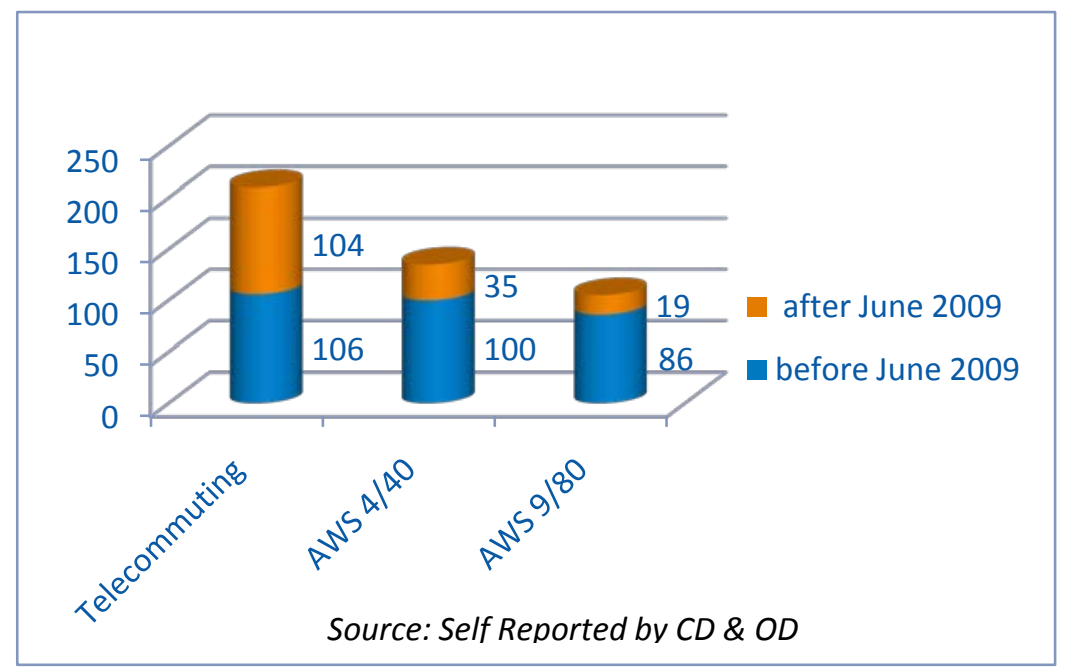

Figure 11. Number of employees telecommuting and AWS

Flexible work place practices Conferencing by video, telephone, and the internet as well as alternative work schedules (AWS) provide flexibility in how people work-saving time, energy, and money. An AWS policy allows employees to work varying schedules (with management approval), including four-day workweeks-reducing the miles driven by employees to and from the laboratory.

\section{Telecommuting}

A Telecommuting Pilot program began in FY 2009 and was offered to 492 employees in twelve NREL Offices and Programs. The pilot program's success is resulting in a laboratory-wide program which will be available to all NREL employees in FY 2010. There are many benefits in telecommuting including:

- High Performing Workforce. Higher morale and commitment, improved recruitment and retention of global talent

- Sustainability. Reduced $\mathrm{CO}_{2}$, energy use, waste generation, facility size, parking requirements, traffic impact on- and off-site

- Economics. Reduce employee commuting costs (fuel and vehicle maintenance)

- Supports work-life balance.

International and domestic air travel represents $63 \%$ of the total commuter miles traveled. The pie chart below summarizes the various commuting methods used by NREL. However the use of video conferencing, webinars, etc., displaced approximately 553 flights, 3,300 air miles, and 3,868 hours of 
flight time. This calculation was based on activities of the laboratories two main offices located in: Golden, Colorado and Washington D.C. In FY 2009, it is estimated that NREL's audio, video conferencing, and webinars increased approximately 45\% from FY 2008.

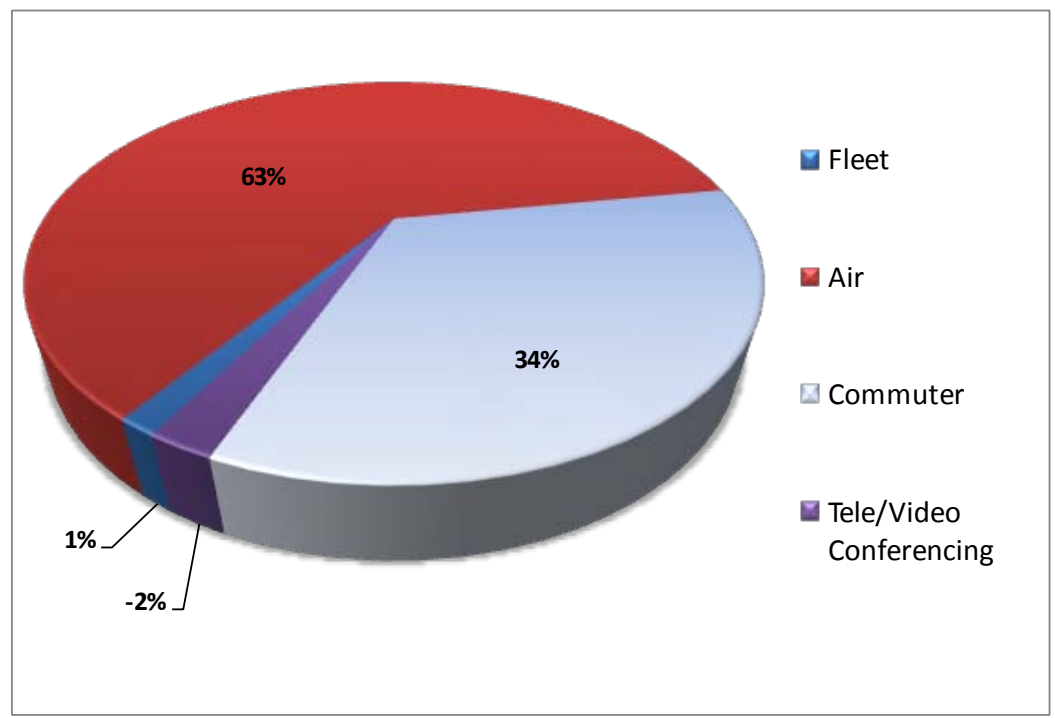

Figure 12. FY 2009 commuter miles

\section{Water Conservation}

\section{Water Use Reduction Goal}

DOE Order 430.2B: Beginning in FY 2008, NREL will reduce water consumption intensity by $2 \%$ annually through the end of FY 2015 or $16 \%$ by the end of FY 2015, relative to the baseline water consumption in FY 2007.

Progress: In FY 2009, NREL reduced its water consumption by 27\% relative to the FY 2007 baseline. To exceed the overall reduction goal of $16 \%$, NREL will continue to incorporate water saving measures in all new construction facilities to achieve the minimum LEED Gold rating.

The FY 2007 NREL water consumption baseline is 13.2 million gallons or a water consumption intensity of 28.7 gallons/sq. ft. In 2009, NREL reduced its water consumption by $27 \%$ relative to the FY 2007 baseline. For FY 2009, the S\&TF had a water consumption intensity of 20.79 gallons/sq. ft. The table below shows the total annual laboratory water consumption from FY 2005 to FY 2009.

NREL will incorporate water conservation measures in all new construction facilities as a part of achieving the minimum LEED Gold certification. Meeting LEED requirements will result in a 34\% water consumption reduction at the RSF. Based on the RSF design; this facility will consume 786,700 gallons of water-a water consumption intensity of 3.6 gallons/sq. ft. For existing building water conservation retrofit goals have been established and are being implemented.

NREL reduced its water consumption by $27 \%$ in FY 2009 relative to the FY 2007 baseline. 


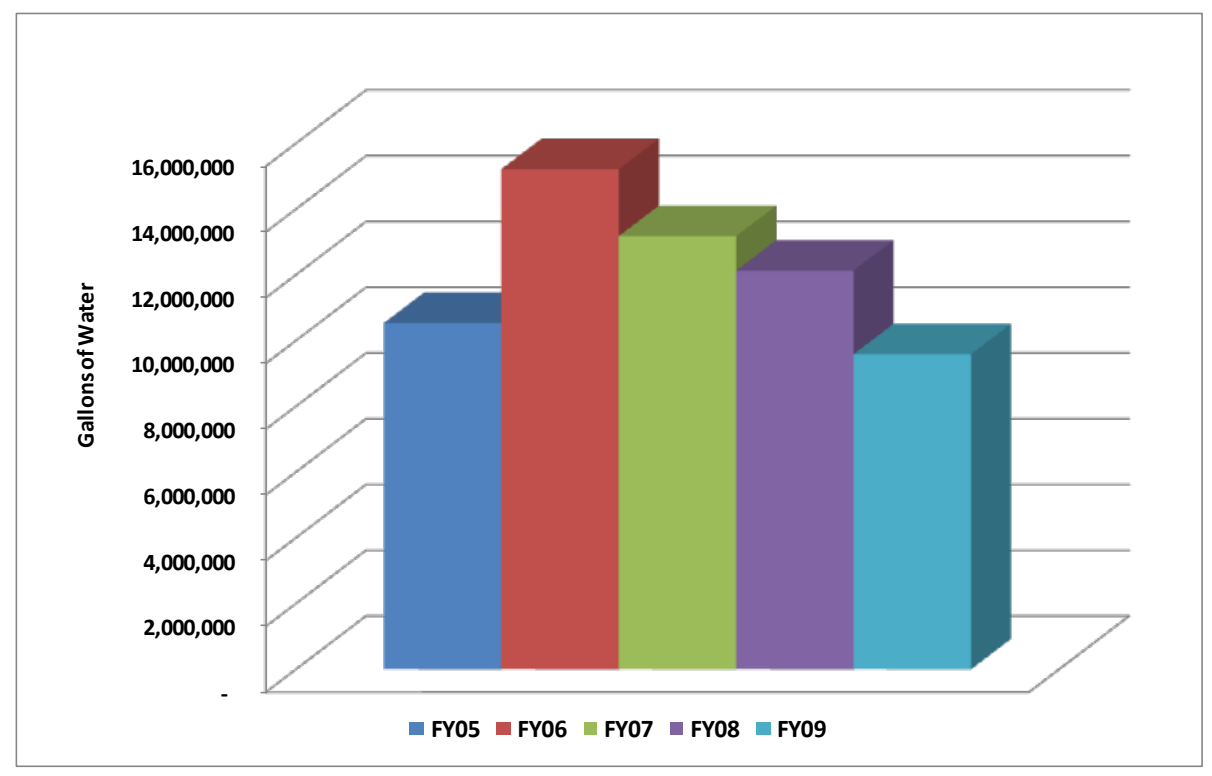

Figure 13. NREL water consumption

\section{Material Use}

\section{Material Use Goals:}

DOE Order 430.2B: Ensure that the laboratory reduces the quantity of toxic and hazardous chemicals and materials acquired, used, or disposed of by the laboratory; increase diversion of solid waste as appropriate; and maintain cost effective waste prevention and recycling programs.

NREL Goal: Near Zero Waste (working to eliminate the laboratory's waste stream).

Progress: Since FY 2003, NREL's recycled waste has increased by 58\%, even with our campus increasing by 117,263 sq. ft. This does not include scrap metal, batteries, e-waste, and other items. NREL has implemented comprehensive reduce, reuse, recycling, and re-buy activities.

NREL is working toward near-zero waste - taking the 4Rs program (reduce, reuse, recycling, and rebuy) to a higher level—systematically eliminating the laboratory's waste stream.

\section{Reduce}

NREL reduces material use by:

- Replacing paper drafts with electronic files

- Installing duplex modules on all network printers for double-sided printing option

- Reusing cardboard boxes, packing peanuts, plastic containers, and drums

- Sharing chemicals and redistributing extra chemicals through a chemical management system. 


\section{Reuse}

NREL's Reusable Office Supply Depot provides opportunities for centers and offices to save money and help the environment by reusing office supplies that could end up in a landfill. Staff members are encouraged to take (and reuse) office supplies from the depot or donate any new or good-as-new items for others to use.

\section{Recycle}

NREL's long-established recycling effort includes a recycling station in each building. All recyclable materials are comingled in specified bins; there are separate bins for large cardboard; containers for batteries; designated areas for printer toner cartridges; and each office /cubicle contains a small recycle basket. Scrap metal, wooden pallets, computer monitors, and fluorescent light bulbs are also recycled.

Prior to FY 2005, all recycled materials were separated and weighed and a monthly report was provided to NREL. In FY 2005 the recycling vendor went to a single stream, comingled pick-up. They were unable to give weights and provided NREL with estimates based on the different sizes of recycle bins. In FY 2009 they provided NREL with a measurement system to more accurately calculate the weights for each pick-up.

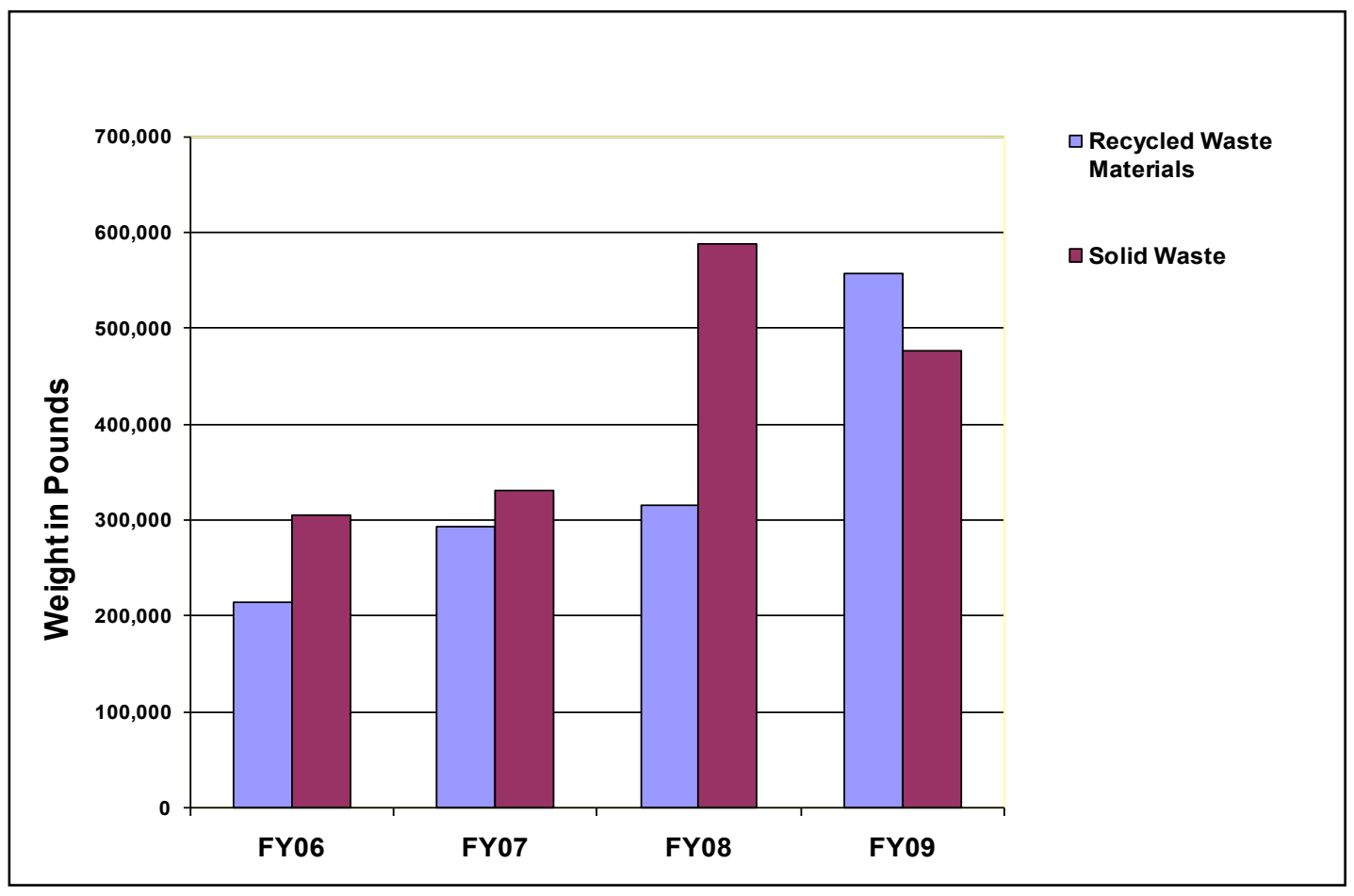

Figure 14. FY06 - FY09 total waste comparison 
Table 5. Other Recycled Items (By Pounds)

\begin{tabular}{|l|c|c|c|c|}
\hline Breakdown of Recycled Materials & FY06 & FY07 & FY08 & FY09 \\
\hline Scrap Metal & 35,460 & 39,263 & 456,150 & 268,620 \\
\hline Batteries & 4,304 & 3,803 & 64,595 & 11,905 \\
\hline Fluorescent light bulbs & 1,058 & 426 & 260 & 661 \\
\hline Computer monitors & 2,384 & 2,640 & 39,860 & 4,950 \\
\hline Wood & 0 & 0 & 33 & 40,500 \\
\hline E-Waste & 0 & 0 & 0 & 19,280 \\
\hline Concrete & 0 & 0 & $8,106,397$ & 0 \\
\hline
\end{tabular}

* This was a onetime clean up at the NWTC of their "bone yard" which increased the FY 2008 numbers in NREL's solid waste significantly-many materials were not recyclable (fiberglass turbine blades), but all scrap metal was recycled which is reflected in the chart below.

\section{Re-buy}

NREL makes green purchasing possible through an online catalog featuring environmentally preferable (recycled content). These items include binders, paper, pens, post-its, calendars, file folders, etc. The laboratory's biggest purchase is of recycled toner cartridges which totaled \$96k in FY 2009. Since 1999, 100\% of all carpet and office paper have contained recycled content. 


\section{Environmental Programs}

The overarching objective of NREL's EMS and its component programs is responsible stewardship of the environment on its DOE-owned sites, leased properties, and to the extent practicable, on subcontractor and partner sites. NREL strives to protect the natural environment by minimizing or eliminating any adverse environmental impacts resulting from NREL activities. The laboratory's EMS is integrated with other NREL management systems and applies to all research and operations activities. The EMS includes written environmental protection policy and program implementation documents. These are put into practice at all staff and management levels.

NREL's EMS includes components to address waste, air, water, site, natural, and cultural resources, and land and soil issues, among others. Descriptions of the components of the EMS are provided in the following sections of this chapter; sections are organized by resource. Each section is composed of three areas of discussion: a summary of the environmental management of the resource, a discussion of any relevant permitting, and a summary of significant activities that have occurred throughout CY2009.

A summary of NREL's permits, registrations, and notifications are presented in Appendix A. These permits are discussed in the following relevant sections.

\subsection{Air Quality Protection}

\subsubsection{Program Management}

Management in this area is consistent with the following NREL programs: Environmental Permitting and Notification (6-2.1), Air Quality Protection (6-2.5), Ozone-Depleting Substances Management (6-2.6), and Particulate Emissions Control for Construction (6-2.14).

\subsubsection{Criteria, Hazardous, and Non-Criteria Pollutants}

The Clean Air Act and State of Colorado laws and regulations delineate several main categories for air pollutants:

- Criteria air pollutants (e.g., carbon monoxide, nitrogen oxides, sulfur dioxide, particulate matter, ozone, and lead, all for which National Ambient Air Quality Standards exist)

- Non-criteria pollutants (e.g., ammonia, hydrogen sulfide, pesticides, organic compounds classified as ozone precursors, metallic compounds, greenhouse gases, and corrosives)

- Hazardous air pollutants (e.g., includes organic compounds, metals, corrosives, asbestos, radionuclides, and pesticides)

- Ozone depleting substances (e.g., chlorofluorocarbons or "freons").

There are notification and permitting thresholds for criteria, hazardous, and non-criteria pollutants. The primary potential sources of these pollutants at NREL include boilers, emergency generators, experimental laboratory hoods, pilot scale research projects, and small pieces of equipment with gasoline or diesel engines. NREL maintains air emission inventories to track potential air emissions and identify whether notification and permitting could be required for a particular facility or activity. Fugitive particulate emissions from construction activities occurring on NREL's sites are also a potential source. 


\subsubsection{Ozone Depleting Substances}

Facilities that service refrigeration equipment containing ozone-depleting substances (ODS) are required to file an annual notification with the CDPHE. NREL employs EPA-certified technicians that service ODS-containing equipment. Another requirement of the state's Chlorofluoro Carbon program is that all refrigeration equipment larger than $100 \mathrm{hp}$ that uses ODSs be registered with CDPHE. NREL has a total of three chillers that are registered with CDPHE; two located at the Solar Energy Research Facility (SERF) on the STM Site, and one at the DWOP.

Halon-based fire suppression systems previously used at NREL were eliminated by 1999, with all supplies of Halon being transferred to other DOE facilities for "banking."

\subsubsection{Street Sanding}

CDPHE regulations require federal, state, and local government facilities to track street sanding in the wintertime, and to make efforts to minimize sand use. NREL complies with this requirement and files an annual sanding report with CDPHE. From October 2008 to May 2009, NREL used 79 tons of sand during 24 sanding episodes, while continuing to maintain 12.3 lane-miles of road. From October 2009 to May 2010, NREL used 50 tons of sand and 36 tons of Ice Slice in 25 sanding deployments in maintaining 12.3 miles of roadway.

\subsubsection{Permitting}

Most potential sources of air emissions from NREL laboratory and facility operations in 2009 were of small scale and did not require permitting. Permitting thresholds vary, depending on the pollutant. Projected emissions for these sources were below thresholds for air permitting.

Two site-wide permits for particulate emissions from construction activities have been issued to NREL by CDPHE. NREL has held such permits for a number of years. New site-wide permits were issued in February 2005 to replace previously held permits for which the time period of applicability had expired. One permit covers the STM site and the other covers the NWTC.

Two Air Pollution Emission Notices (APENs) were filed in early 2005, one for the STM and one for the NWTC, for overlot grading and associated construction activities to address fugitive particulate emissions. The APEN for the NWTC will expire in 2010.

NREL also holds one air emissions permit for an experimental pilot process in the Field Test Laboratory Building (FTLB) on the STM Site. The permit was issued in 2000 for the operation of a thermal oxidizer emission control device for the experimental Thermochemical Process Demonstration Unit (TCPDU). An APEN update was filed with the Colorado Air Pollution Control Division in 2005.

\subsubsection{Activities}

In late 2008 NREL filed a new APEN for upcoming major construction activities anticipated in the upcoming 5 years at the STM site. Significant activities not associated with routine maintenance or small construction projects identified in the APEN submission were evaluated on a case-by-case basis in 2009. As a result of this evaluation, it was not necessary to submit an updated APEN.

As required by CDPHE every five years, an APEN update was filed in May 2005 to update the information provided in the original APEN for TCPDU activities. There have been no significant 
changes to the operating parameters or air emissions of the TCPDU in the last several years, including 2009.

In early 2007, NREL received initial approval from CDPHE's Air Pollution Control Division for the construction and operation of a woodwaste-fired boiler to provide building comfort heating for the STM campus. Prior to the completion of construction, additional information became available regarding the configuration of the equipment and it was necessary to request a permit modification. CDPHE issued an initial approval for the permit modification in the fall of 2008. Construction of the woodwaste-fired boiler was completed and the equipment became operational in late 2008. In April 2009 NREL completed the self-certification process for final approval and submitted the required documentation to CDPHE.

\subsection{Drinking Water}

\subsubsection{Program Management}

Management in this area is consistent with the following NREL Programs: Drinking Water (6- 2.3) and Environmental Permitting and Notification (6-2.1).

Drinking water is provided to NREL's STM and DWOP sites by a public water supply, Consolidated Mutual Water Company. Water to the Joyce Street and ReFUEL Facilities is also provided by a public water supply. NREL supplies drinking water to its NWTC by trucking in water from local public water supplies through a subcontracted water hauler. NREL stores the water on site in a buried 15,000-gallon storage tank and an above ground 2,000-gallon tank. The water hauler fills the 15,000gallon tank, and water is pumped on demand to the 2,000-gallon tank where it is distributed to the Industrial User Facility (IUF), Building 251, and the Distributed Energy Resource Test Facility (DERTF) on the west end of the site.

Disinfection boosting is performed at the NWTC using an automated chlorine disinfection system.

Monitoring for bacteria (total coliforms), chlorine levels, haloacetic acids, and trihalomethanes (disinfectant by-products), and lead and copper is performed at the NWTC according to the requirements of CDPHE. NREL qualifies for reduced lead and copper monitoring. Current state requirements for NWTC system monitoring are as follows:

- Bacteria-monthly

- Chlorine levels-weekly, or more frequently as needed

- Haloacetic acids (HAA5)-annually

- Total Trihalomethanes (TTHM)-annually

- Lead and copper-triennially.

Samples are collected from three locations at the NWTC: Building 251, the IUF, and the hydrogen test pad. No coliforms were detected in any of the samples taken during 2009. Monthly results for the bacterial analyses are provided to the state.

The most recent triennial monitoring for lead and copper was completed as scheduled during the summer of 2008. All samples collected were well below the maximum contaminant levels (MCL). Five sampling locations were tested for lead and copper. Four of the five lead results were below detection with the fifth result showing $0.002 \mathrm{ppm}$, well below the MCL of $0.015 \mathrm{ppm}$. Copper values 
ranged from $0.095 \mathrm{ppm}$ to $0.474 \mathrm{ppm}$, with an average value of $0.200 \mathrm{ppm}$, well below the MCL of $1.3 \mathrm{ppm}$. The next sampling for lead and copper will occur in 2011.

Chlorine residual monitoring of the NWTC drinking water system began with the installation of the chlorine disinfection system in 2000. Monitoring is performed to ensure the chlorine residual levels are detectable, with a target concentration of at least $0.2 \mathrm{mg} / \mathrm{L}$ of chlorine present to provide sufficient disinfection at the monitoring locations. Colorado requires that chlorine residual monitoring occur when collecting monthly bacterial samples. NREL monitors chlorine residual levels in the system on a weekly basis and also measures chlorine levels of drinking water that is delivered to the NWTC. Results are provided to the state on a monthly basis. Chlorine was present at appropriate levels in all samples collected in 2009. The running annual average of the maximum residual disinfectant level for CY2009 was $0.518 \mathrm{ppm}$.

If any treatment is performed on supplied drinking water, state regulation requires that a statelicensed operator supervise the treatment. NREL hires a subcontracted operator with a Class A license to supervise the disinfection and filtration operations and to perform the necessary sampling.

\subsubsection{Permitting/Notifications}

NREL has a registered Public Water Supply Identification Number (PWSID) issued by CDPHE for the drinking water distribution system at the NWTC. This identification number does not require periodic renewal, but periodic testing, record keeping, and reporting are required. All other NREL facilities (STM, DWOP, JSF, and ReFuel) are provided drinking water from municipal sources.

\subsubsection{Activities}

In 2009, 251,040 gallons of potable water were delivered to the NWTC, and average daily consumption rate of 687 gallons. NREL conducted all required monitoring in 2009 and all reported results met drinking water standards. Bacteria were absent in all samples collected, and disinfectant was detected at all locations tested. The annual running average for chlorine was $0.518 \mathrm{ppm}$.

It was previously reported that CDPHE notified NREL of an exceedance of the maximum contaminant level for total trihalomethanes (TTHMs). As a result, quarterly monitoring for disinfection byproducts (DBP) was implemented in 2006 and continued throughout 2007 and 2008. While only the maximum containment level for TTHMs was exceeded, state regulations require monitoring for HAA5s as well as TTHMs. The running annual average (RAA) for TTHMs in 2009 was $0.056 \mathrm{mg} / \mathrm{L}$, below the maximum contaminant level of $0.080 \mathrm{mg} / \mathrm{L}$ and in compliance with the water quality requirement. The RAA for HAA $5 \mathrm{~s}$ was $0.043 \mathrm{mg} / \mathrm{L}$, below the maximum contaminant level of $0.060 \mathrm{mg} / \mathrm{L}$, also in compliance with the water quality requirement. The RAAs for DBPs were also below the state's regulatory requirement to return to routine monitoring. CDPHE notified NREL on October 20, 2008 that NWTC system had returned to routine reporting (i.e., annual) for DBPs. While monitoring is only required once per year, NREL continued to monitor DBPs on a quarterly basis through 2009 .

The 2007 ASER (dated November 2008) first reported that CDPHE's Water Quality Control Division conducted a formal Sanitary Survey of the NWTC drinking water system in 2008. The inspection was conducted on September 23, 2008, and the system was found to be in compliance with all requirements. Three recommendations for improvement were identified during the survey: 


\section{Observation 1. Monitoring and Reporting and Data Verification}

"The system should continue to evaluate source water quality from the wholesaler, the system's booster chlorination system, and the amount of residence time in the storage tank, and distribution system in order to minimize formation of disinfection by products."

\section{Observation 2. System Operations and Maintenance}

"It is recommended that the system develop and implement a valve exercising program for valves in the distribution system in order to maximize the life of such devices."

\section{Observation 3. Storage Management}

"It is recommended that the water system create a tank maintenance plan to evaluate and inspect the condition of the buried storage tank and to ensure the tank is a safe and viable component of the water system. Preventative maintenance and timely inspections will help prolong the life of the tanks and ensure early detection of needed repairs. The water system should examine the tank and piping, and look for signs of compromised integrity and leaks on a yearly basis. Additionally, the water system should routinely inspect the integrity of the access manhole and vents on a frequent basis to ensure the sanitary integrity of these components. In addition to the tank maintenance plan, the water system should have the tank drained, cleaned, and professionally evaluated every three to five years (as recommended by the American Water Works Association)."

In 2009, samples of the delivered water were collected and tested for disinfectant byproducts to address Observation n 1. Levels of TTHMs and HAA5s were consistent with the running annual average. Site Operations has taken the remaining observations under consideration.

\subsection{Groundwater}

\subsubsection{Program Management}

Management in this area is consistent with NREL's Groundwater Protection Program (6-2.4).

Both the STM and the NWTC are located at the western edge of the Denver Basin aquifer system that supplies water to urban, rural, and agricultural users along the Front Range of the Rocky Mountains in northeastern Colorado. The aquifers within the Denver Basin, which include the Dawson, Denver, Arapahoe, and Laramie-Fox Hills aquifers, form a layered sequence of rock in an elongated bowl-shaped structural depression.

The shallowest aquifer is the Dawson formation that is located between 60'-100' below ground surface (bgs) and extends to approximately 1,000 feet bgs. This is followed by the Denver aquifer, the Arapahoe aquifer, and finally the deepest aquifer, the Laramie-Fox Hills aquifer which extends from approximately 2,270 feet to 2,970 feet bgs. Thicknesses of the aquifers decrease with depth below ground surface ranging from 1,100 feet in the Dawson, 400-800 feet in the Denver, 500-600 feet in the Arapahoe, and 200 feet in the Laramie-Fox Hills aquifer. Limited connection exists among these deep aquifers and with the shallow alluvial aquifers associated with the South Platte River valley and its tributaries. 
The STM site overlies the shallowest portions of the Denver, Arapahoe, and Laramie-Fox Hills aquifers. The NWTC site overlies the shallowest portions of the Arapahoe and Laramie-Fox Hills aquifers. The northern extent of the Dawson aquifer is located approximately twenty miles to the south and east of the STM site; consequently, wells drilled at the STM site and NWTC would not intersect the Dawson aquifer.

Because of the sensitive nature of the groundwater resource, NREL carefully evaluates all outdoor projects to eliminate potential impacts to groundwater quality. If any materials are used that pose a risk to groundwater, the laboratory typically insists that safeguards to protect groundwater be established. Safeguards include, but are not limited to, secondary containment for equipment with the potential to leak oil, double-walled tanks with leak detection for diesel fuel storage of NREL facilities' emergency generators, and bermed areas to contain experimental materials.

In 1990, groundwater characterization began with the installation of a monitoring well network at the STM site. Eight wells were installed at the base of the mesa slope. Four upgradient wells were installed to investigate background water quality prior to its crossing NREL facility boundaries, and four wells were placed in a generally downgradient direction to verify that NREL activities had not adversely affected groundwater quality. Quarterly sampling was performed for five calendar quarters, followed by annual sampling for three years. No evidence of contamination was found. Groundwater quality at NREL was similar to other portions of the Denver Basin. In addition, routine follow-up sampling was done in 1997. Three of the initial eight wells were closed (in accordance with state requirements) due to construction activities in 1993, and a fourth was found to be inaccessible during the 1997 sampling, also due to construction activity in the area. Therefore, follow-up samples were only collected from four of the original monitoring wells: three upgradient wells and one downgradient of NREL development. No evidence of contamination was found in the 1997 sampling.

In June 1998, a diesel leak to the environment from a failed check valve on the PDU emergency generator aboveground storage tank at the Alternative Fuels User Facility occurred. The majority of contaminated soil was excavated and removed from the site for disposal at a permitted landfill. Three groundwater monitoring wells were installed at the site in September 1998, one upgradient and two downgradient. No hydrocarbon contamination was detected in the groundwater during the initial sampling of the three wells, or during follow-up sampling conducted in March and September 1999, and March 2000. These three monitoring wells were closed in 2006 in accordance with state requirements.

The NWTC currently has no open or active groundwater wells. A water supply well once provided water to Building 251 when DOE's Rocky Flats Field Office operated the site. In 1993, NREL collected samples from the well and the associated water distribution and treatment system as part of an evaluation of alternatives for water supply to the site. Based on the sampling results, it was determined that the maintenance and repairs required to make the existing well and treatment system effective were extensive, and there was an indication of the potential for trace organic compounds in the water. Therefore, when DOE's Golden Field Office assumed landlord responsibility for the site in 1993, the connection between the building and the well was severed. The water supply well was plugged and abandoned in accordance with state regulations in 1996. Potable water is currently transported to the site, as described in Section 5.2 of this report. NREL has done no other groundwater sampling at the site. 
NREL has not conducted groundwater monitoring at its leased DWOP site, as there have been no activities that pose an unusual risk to groundwater quality. If NREL had reason to suspect a groundwater quality problem, the issue would be addressed with Denver West Management. DWOP management contracted with an engineering firm to conduct a groundwater monitoring study in 1988 adjacent to the NREL-leased buildings. Two monitoring wells were drilled. There were no detections of significant levels of contaminants.

There have been no groundwater studies performed by NREL at either the JSF or the ReFuel Facility, as there have been no activities at these site that pose an unusual risk to ground water.

There is currently no ongoing routine groundwater monitoring program on any NREL site. Groundwater sampling will be conducted if future activities pose a risk to the groundwater quality.

\subsubsection{Permitting}

All groundwater monitoring wells installed by NREL at the STM sites have been permitted with the Colorado Department of Natural Resources.

\subsubsection{Activities}

In 2009, there were no new groundwater-related activities.

\subsection{Wastewater Discharge}

\subsubsection{Program Management}

Management in this area is consistent with NREL's Waste Management and Minimization Program (6-2.8).

The majority of wastewater from NREL's STM and DWOP facilities flows into the Pleasant View Water and Sanitation District's system, and ultimately to Metropolitan Wastewater Reclamation District's (Metro) treatment plant. There is a small septic system consisting of a tank and absorption field on the mesa top, serving the Solar Radiation Research Laboratory (SRRL), because there is no sewer line to the mesa top. Wastewater from the JSF and the ReFUEL facility also flows to Metro's treatment plant. The NWTC is not connected to a sewer system, but has two septic systems that include tanks and absorption fields for the treatment of wastewater.

It is NREL policy to comply with all requirements of Metro's Pretreatment Program, including the list of general prohibitions that protect the collection and treatment systems. The list of prohibitions includes hazardous materials, highly viscous substances, radioactive material, excessive oil and grease, and similar substances that could cause material harm to the sanitary system. NREL staff is trained in this policy. In addition, NREL sites have design criteria for waste drains in lab areas to minimize the possibility of a hazardous material discharge. These criteria include measures such as secondary containment for any chemicals used near sinks in laboratory exhaust hoods, no floor drains in laboratory areas unless a specific need can be shown, and caps for any floor drains that are installed in lab areas. New research and operations activities as well as ongoing activities that undergo significant modifications are reviewed for their potential effect on wastewater character through NREL's risk assessment process. 


\subsubsection{Permitting}

No permitting for the majority of NREL's wastewater discharges is required. NREL has no direct wastewater discharges to the environment at the DWOP, ReFUEL, or JSF, so no National Pollutant Discharge Elimination System (NPDES) permitting is necessary. NREL maintains three individual sewage disposal systems, two at the NWTC and one at the STM site. The remainder of NREL facility wastewater is discharged to Metro through the sanitary sewer system. NREL facilities are currently classified by Metro as non-industrial water users at these sites. As non-industrial users, NREL sites do not need a permit from Metro for sewer discharge, and monitoring for pollutants in wastewater is not required.

NREL maintains septic permits from Jefferson County (an authority delegated to the counties under a State of Colorado program) for the NWTC's IUF and Building 251 septic systems, as well as for the SRRL facility on the STM site mesa top.

\subsubsection{Activities}

In 2009, there were no new wastewater discharge activities.

\subsection{Surface Water Protection (Stormwater and Erosion Control)}

\subsubsection{Program Management}

Management in this area is consistent with the following NREL Programs: Storm water Pollution Prevention for Construction Activities at the STM (6-2.15), Storm water Pollution Prevention for Construction Activities at the NWTC (6-2.16), and the Environmental Permitting and Notification (6-2.1).

\subsubsection{Past Investigations}

Historically, storm water monitoring was conducted at the STM site during the summers of 1992 and 1993 to characterize storm water quality at NREL, confirm that NREL's activities were not adversely impacting storm water quality leaving the STM site, and provide a baseline against which future sampling could be compared.

Samples were collected at 3 locations: the western portion of the East Drainage, the Middle Drainage, and the Middle West Drainage located between the West and Middle Drainages. Water quality data indicate that NREL's activities did not result in contamination of storm water runoff. For that reason, instream water quality samples of Lena Gulch, the receiving water to which storm water from the STM site ultimately flows, were not collected.

Lena Gulch is a tributary to Clear Creek, a major waterway in the west Denver region. The Urban Drainage and Flood Control District has mapped the 100-year floodplains of this region and determined that none of the NREL facilities encroach upon a floodplain.

In 1998, surface water samples were taken in two drainages at the NWTC in connection with NREL's weed control efforts. No traces of the herbicide applied to weed-infested areas were detected in the water samples collected. Storm water and surface water quality monitoring has been conducted at NREL's DWOP, JSF, and ReFuel sites. 


\subsubsection{Current Management Practices}

Outdoor research projects and building construction are reviewed during the planning stages through NREL's NEPA, risk assessment, and design review processes for potential impacts to storm water and receiving waters. Measures to prevent impacts to storm water are incorporated, as appropriate, into the design for each project. Potential control measures include secondary containment and bermed areas for chemicals use and storage, covers or roofs to protect chemical use, and storage areas from precipitation and minimizing impervious areas to promote infiltration and decrease site runoff.

During construction, erosion and sediment controls are implemented according to the plans developed by contractors and reviewed by NREL EHS staff per NREL storm water procedures. Regular inspections by contractors and periodic site inspections by NREL staff are conducted to verify that the controls are functioning properly and to identify any required repairs. Written reports are prepared for all inspections; prompt corrective actions are required to correct any noncompliant conditions.

\subsubsection{Permitting}

Storm water quality on federal facilities in Colorado is regulated by the U.S. EPA Region 8. To obtain coverage under USEPA's National Pollutant Discharge Elimination System (NPDES) General Construction Storm water permit, NREL must submit a Notice of Intent (NOI) form. The site owner (DOE), site operator (Alliance for Sustainable Energy or previously, Midwest Research Institute), and construction subcontractors have filed NOIs with the EPA.

In 2009, NREL continued construction activities at the STM site for the Research Support Facility (RSF) and associated storm water detention basin and access road covered by an NOI filed in 2008. New NOIs were filed for the Integrated Bio-Refinery Facility (IBRF) and the RSF Infrastructure Project and at the NWTC a new NOI was filed for the Sun Edison 1MW photovoltaic array field.

\subsubsection{Activities}

In addition to implementation of storm water pollution prevention plans associated with permitted construction projects described above, NREL also applied numerous storm water protection and erosion control practices and controls on small project sites for which General Construction Storm water permits were not required. These were primarily located at the NWTC where the following activities occurred over the course of the year: placement of new data sheds and pads at Sites 3.3, 4.0 and 4.4, placement of a new trailer near Building 251, construction of foundations for wind turbines at Sites 1.2E, 3.3A, 3.3B and 3.3C, construction of foundations for meteorological towers at Site 3.3, and construction of a hydrogen vehicle fueling island at the DERTF.

\subsection{Waste Management}

\subsubsection{Program Management}

Management in this area is consistent with the following NREL Programs: Waste Management and Minimization (6-2.8) and Environmental Permitting and Notification (6-2.1).

Hazardous wastes are handled and disposed of according to the Resource Conservation and Recovery Act (RCRA) and the Colorado Hazardous Waste Act. NREL's waste primarily consists of a broad range of hazardous laboratory chemicals in small quantities. Wastes in solid or liquid form are 
collected in each laboratory or at each experiment site and prepared for off-site disposal by the NREL EHS personnel.

Hazardous waste is transported to EPA-permitted facilities for treatment and disposal. In addition, NREL has a conservative waste management policy where materials that are not regulated by RCRA, yet pose a potential hazard, are collected and disposed of as non-hazardous materials at RCRApermitted disposal facilities. This category includes nanomaterial-bearing wastes, which were added to the waste procedure in 2008 and management of these materials continued into 2009.

NREL facilities also generate small quantities of low-level radioactive wastes. This waste normally consists of personal protective equipment, disposable labware, scintillation fluids, and water-based liquids. Radioactive waste is shipped off-site for disposal on an as-needed basis.

\subsubsection{Permitting}

NREL has five separate sites that have the potential to produce quantities of hazardous waste in various amounts. Each of the five sites has a RCRA waste generator identification number issued by the State of Colorado. The STM location is classified as a "small quantity generator," generating less than $1,000 \mathrm{~kg}$ of waste per month. The other four sites-the Joyce Street Facility, the National Wind Technology Center, the Denver West Office Park, and the ReFUEL facility-are classified as "conditionally exempt small quantity generators," generating less than $100 \mathrm{~kg}$ of waste per month.

\subsubsection{Activities}

In CY2009, NREL shipped 15,943 pounds $(7,246 \mathrm{~kg})$ of hazardous waste, 2,348 pounds $(1,067 \mathrm{~kg})$ of non-RCRA regulated waste, and 15,141 pounds $(6,882 \mathrm{~kg})$ of universal waste for disposal and recycling from all five sites combined. Universal waste includes batteries, fluorescent light bulbs, and electronic equipment. In CY2009, there was a 45\% reduction in the amount of hazardous waste shipped from the CY2008 levels.

In 2009, no radioactive waste was shipped for off-site disposal. However, in September 2008, work began in the FTLB using phosphorus-32, a radioactive isotope. Waste generated by these activities was collected in May and November 2009. Information regarding the types and quantities of radioactive materials used at NREL facilities is detailed in Section 5.16.

In 2007, a number of national laboratories, including NREL, developed an approach for the management of nanomaterials at DOE facilities. In 2008, DOE directed the laboratories to implement control programs at the laboratories for nanomaterials and for wastes that contain these substances. NREL developed a program that instituted administrative and engineering controls on the use of nanomaterials, the creation of nanoparticles, and the management of nanomaterial-bearing wastes. Because there is some uncertainty surrounding the risk of these substance to human health and the environment, DOE and the national laboratories have take a conservative approach to the use and disposal of nanomaterials. In CY2009, NREL continued to implement the management procedures for nanomaterial-bearing waste as described in the update Waste Management and Minimization procedure. This material is collected and stored as hazardous waste, and ultimately sent to licensed treatment storage and disposal facilities (TSDFs) for disposal.

In CY2008, in anticipation of a rise in the amount of generated waste, NREL increased the waste management training requirements to once per year, implemented documented weekly inspections of all waste collection areas, and began regularly shipping waste off-site every 90 days. The increase 
training requirements and the weekly inspections will satisfy the regulatory requirements anticipated when waste production increases to above the large quantity generator threshold. Waste inspectors are selected for each laboratory in which waste is generated; these areas are designated Satellite Accumulation Areas. The inspector is responsible for conducting weekly inspections and documenting them on forms submitted to the EHS organization. These practices continued throughout CY2009.

\subsection{Storage Tanks (Underground and Aboveground)}

\subsubsection{Program Management}

Management in this area is consistent with the following NREL programs: Aboveground Storage Tank Management (6-2.7) and Spill Prevention Control and Countermeasures (6-2.10). NREL does not have any underground tanks with hazardous materials.

NREL facilities store diesel fuel for emergency generators and ethanol from research activities in aboveground storage tanks. NREL's tank management program focuses on proper tank design, operation, and inspection to protect against spills and leaks. The program is designed to meet regulatory requirements and is more stringent in some aspects than regulations require.

Several important mechanical and procedural safeguards have been incorporated into NREL's tank management program to prevent any accidental releases of diesel fuel from the storage tanks. Mechanical safeguards include overfill and spill protection, double wall tanks for diesel fuel equipped with sensors that result in an alarm if the inner tank wall is leaking, and a exterior concrete containment structure for the ethanol storage tank. Procedural safeguards include written operating procedures and tank filling procedures. All tanks larger than 110 gallons are visually inspected at least once per month.

Due to the quantity of fuels stored on the STM, NWTC, and ReFUEL sites, a Spill Prevention Control and Countermeasures Plan is required for each of these locations. This plan describes the topography of each site and neighboring areas, and outlines the steps necessary to mitigate any spills or leaks of diesel fuel. To date, NREL has not had any off-site impacts related to tank activities.

\subsubsection{Permitting}

Aboveground tanks larger than 660 gallons require annual registration with the State of Colorado. Currently, only two tanks meet the registration threshold: the SERF emergency generator diesel storage tank and the Process Demonstration Unit (PDU) ethanol storage tank at the AFUF. Both are located on the STM site.

\subsubsection{Activities}

There were no inspections in 2009. No spills or releases from NREL's ASTs occurred during 2009.

\subsection{Hazardous Materials Management}

\subsubsection{Program Management}

Management in this area is consistent with the following NREL programs: Chemical Safety Program (6-4.6) and Asbestos Management Program (6-4.18). 
No active or abandoned hazardous waste sites have been identified on any of the laboratory sites. Therefore, many sections of the Comprehensive Environmental Response, Compensation, and Liability Act do not apply to NREL facilities.

NREL facilities are subject to the EPCRA Section 302 emergency reporting provisions which require a facility to notify the State Emergency Response Commission (SERC) if any extremely hazardous substances in the facility's inventory are stored in quantities greater than prescribed threshold planning quantities (TPQ). NREL facilities first became subject to planning and notification requirements in 1988, but the laboratory inventory of extremely hazardous substances has never exceeded the TPQ.

EPCRA Section 304 requires facilities to immediately notify the Local Emergency Planning Committee (LEPC) if there is an accidental spill or release of more than the predetermined RQ. In accordance with Section 311 and 312 of EPCRA, NREL provides Material Safety Data Sheets (MSDS) for chemicals that are stored on-site in quantities greater than TPQs, and provides inventory reporting for these same chemicals in the form of Tier I or Tier II reports to emergency planning and response groups.

When requested, NREL provides additional emergency response and reporting information to the Jefferson County LEPC, the SERC, the West Metro Fire Rescue District (West Metro), and the Rocky Mountain Fire Protection District. The Jefferson County LEPC uses hazard categories and threshold reporting quantities as defined by the Uniform Fire Code rather than those specified in SARA Title III, resulting in a larger number of individual hazard categories and lower reporting thresholds. NREL has been represented in the LEPC since its inception and is actively involved in the emergency planning concepts of SARA Title III with two acting members on the Jefferson County LEPC.

The laboratory is also subject to reporting requirements in the event of a release of an RQ of any hazardous substance listed by EPCRA. EPCRA Section 313 requires that a toxic chemical release inventory report (Form R) be filed with the EPA for any chemical that is manufactured, processed, or otherwise used in quantities exceeding TPQs. Although NREL is not a manufacturing facility and does not fall within any of the standard industrial classification (SIC) codes for which Section 313 reporting is required, EO 12856 requires all federal facilities to file a report, if applicable, regardless of SIC code. NREL has never manufactured, processed, or otherwise used chemicals on the 313 list in quantities exceeding TPQs nor have there been any releases of material, so NREL has never had to report under Section 313.

Section 112r of the Clean Air Act regulates numerous toxic and flammable substances, and, similar to EPCRA, establishes threshold quantities for these materials. Unlike EPCRA, however, the Section $112 \mathrm{r}$ threshold quantity applies to the amount of substance in a single process, not the entire facility. To date, NREL has not met the thresholds that trigger applicability of Section 112r.

NREL has a laboratory-wide chemical management system (CMS) that serves as a centralized chemical inventory as well as a tool for managing and reporting on chemicals used at the laboratory. Using an electronic bar-coding system, the CMS tracks chemicals from the point of receipt through end-use and disposal. The system also contains technical data and reporting information for many of the chemicals in the CMS database. Key functions of the system include:

- Providing current inventories by room, building, and/or site 
- Improving research efficiency and minimizing hazardous waste generation by allowing staff to determine if needed chemicals are already available on-site prior to making chemical purchases

- Providing quick access to chemical inventories and hazard information during emergency responses

- Facilitating accurate and efficient reporting to external agencies (e.g., fire districts, LEPC, EPA, and DOE).

In 2009, the CMS system was upgraded to new software and hardware to better serve these functions. The EHS organization coordinates the operation of the CMS, but other organizations are critical to keeping the system information up-to-date. Shipping and Receiving is responsible for chemical labeling and data entry, Information Services provides support for the dedicated server that hosts the CMS, and researchers are responsible for reporting the transfer and disposal of chemicals.

Asbestos surveys have been conducted in a number of NREL facilities: the Joyce Street Facility, Building 251 at the NWTC, Building 16, the STM Site, the AFUF (only older areas of the building), the FTLB, and the SRRL. No asbestos was found at the Joyce Street Facility and the AFUF. The other facilities have limited amounts of asbestos-containing material in areas such as floor tile, lab countertops, caulking and sealants, and roofing materials. Asbestos-containing materials are left undisturbed whenever possible. If renovation is planned that will disturb asbestos-containing material, then certified asbestos removal contractors are used and strict asbestos removal procedures are followed. An Asbestos Management Program is in effect for all NREL facilities.

\subsubsection{Permitting}

NREL obtains annual Hazardous Material Permits from West Metro for the STM and DWOP sites. The permits are required by West Metro. NREL obtains permits for a total of six buildings where hazardous materials are stored and/or used. Prior to issuing the permits, a representative from West Metro conducts a walk-through inspection of the entire STM site and DWOP.

The ReFUEL facility is within the jurisdiction of the City of Denver Fire Department (DFD) and is subject to the DFD Hazardous Materials Information System (HMIS) requirements. The ReFUEL Facility's inventory of listed materials, including various fuels such as biodiesel, must be reported to the DFD annually. DFD inspects the facility and issues a Hazardous Materials Permit.

\subsubsection{Activities}

West Metro conducted a walk-through inspection of NREL's STM and DWOP facilities in the summer of 2009. Annual Hazardous Materials Permits for the six buildings were issued following the inspection. The CMS was used to provide complete chemical inventories for each facility as part of the permit application process.

Similarly, the CMS provided inventory information to meet the DFD's HMIS requirements. The ReFUEL Facility's Hazardous Material Permit was renewed by the DFD in July 2009. Finally, the CMS is used to determine if the laboratory had quantities of extremely hazardous substances and other reportable materials that would require the submission of a Tier II report to the LEPC. In 2009, NREL had no extremely hazardous substances that exceed the TPQs. 


\subsection{Pollution Prevention and Sustainability}

\subsubsection{Program Management}

Management in this area is consistent with the following NREL programs: Environmental Management (6-2), Sustainable NREL (2-7), and NREL's EMS description. Most of the activities conducted by the Sustainable NREL program are in the following areas:

- Waste minimization, recycling, and green purchasing

- Transportation

- Energy

- Renewable energy

- GHG emissions

- Water conservation

- Sustainable building design

- Technical assistance and outreach.

The Sustainable NREL Program publishes an annual report that provides the details of accomplishments in the areas of activities listed above. Because the Sustainable NREL Program is closely linked to the Environmental Management System, the program accomplishments of these efforts are covered in Section 4 of this report.

\subsubsection{Permitting}

NREL has no permit requirements applicable to Pollution Prevention and sustainability management. As a DOE facility, NREL does set objectives to meet goals established by federal executive orders (e.g., EO 13423) and DOE orders.

\subsection{Vegetation Management}

\subsubsection{Program Management}

Management in this area is consistent with NREL's Weed Management Programs for the STM and NWTC (6-2.12 and 6-2.13, respectively) and the Sustainable Landscape Design and Management Program (6-2.19).

NREL's approach to vegetation management is to conserve existing ecosystems in their natural state as much as possible. There is some landscaping using non-native drought-tolerant species adjacent to some of the buildings, and even a few areas of bluegrass at the STM site. However, the native vegetation and natural character of the landscape is maintained over the majority of the site.

Revegetation of areas to be left in their natural state following disturbance from construction or other outdoor activities is conducted using a native seed mix of grasses and forbs. These mixes are sitespecific and are composed predominantly of native species that were originally present on the site before disturbance. Seed mix and revegetation procedures are outlined in NREL's Stormwater Pollution Prevention Programs for the STM and NWTC Sites. The use of native species is required at both the STM and NWTC whenever possible. When feasible, high-water demand species like Kentucky bluegrass are replaced with drought-tolerant native species. The most recent vegetation survey of the STM was conducted between June 2001 and May 2002. Five general habitats were described on the STM site, comprising seven plant communities (Plantae Consulting Services, 2002). No rare or imperiled plant species were found on the site. Areas of mixed foothills shrublands (also called tall upland shrubland) were identified on top of the mesa within the conservation easement 
area. This natural community is listed as rare and imperiled by the Colorado Natural Heritage Program. No development will occur in the conservation easement area.

In Colorado, the Department of Agriculture Commissioner, in consultation with the state noxious weed advisory committee, local governments, and other interested parties, develops and implements state noxious weed management plans for three categories of weed species. Class A plants are targeted for eradication while Class B species are subject to management plans designed to stop the continued spread of these species. Class $\mathrm{C}$ species are subject to plans designed to support the efforts of local governing bodies to facilitate more effective integrated weed management on private and public lands. The goal of such plans will not be to stop the continued spread of these species but to provide additional education, research, and biological control resources to jurisdictions that choose to require management of List $\mathrm{C}$ species. Of the noxious weed species that have been identified on the STM site, three - Canada thistle, diffuse knapweed, and musk thistle - are Class B species and one, field bindweed, is on the Class $\mathrm{C}$ list.

A three-season vegetation survey of the NWTC site was performed between August 1999 and August 2000. The survey defined five general habitats on the NWTC site, comprising nine plant communities and 271 vascular plant species (Plantae Consulting Services, 2000). No rare or imperiled plant species were found on the site. However, the survey identified a small area of xeric tallgrass prairie (defined as mesic mixed grassland in this study) located in the southwest corner of the NWTC. This natural community is listed as rare and imperiled by the Colorado Natural Heritage Program. This listing implies no legal designation or regulatory enforcement. It is so designated primarily for management purposes. This area of the NWTC is not impacted by research or construction activities on the site.

Of the weed species identified at the NWTC site, four - Canada thistle, diffuse knapweed, musk thistle, and leafy spurge - are Class B species and one, field bindweed, is on the Class C list. Based on the survey, recommendations were made to continue using a comprehensive weed management program, founded on an integrated pest management (IPM) philosophy.

The survey showed the native seed mix used for revegetation at the NWTC to be very successful in many areas of the site. NREL is continuing the use of this seed mix for revegetation at the NWTC. Weed control efforts have been ongoing since 1997 at the NWTC and 1998 at the STM site. NREL uses an IPM approach that incorporates various types of weed control methods. Some of these include mechanical practices (e.g., mowing), cultural (e.g., reclamation of disturbed areas), prevention (e.g., limiting or eliminating driving of vehicles off established roadways), and herbicide treatment. The effectiveness of control methods is periodically assessed. The use of multiple strategies for control has been successful in significantly reducing populations of diffuse knapweed and Canada thistle on the sites. The key aspect of the weed control program is to maintain flexibility to respond to the changes in weed populations from year to year.

In 1998, aerial herbicide application of Tordon 22K was conducted using helicopter application over about 200 acres of the NWTC to target diffuse knapweed. It was very effective in controlling the weed, and healthy stands of native grasses have proliferated with the decrease in weed competition. Since that time, infested areas of the NWTC have been treated with ground-applied herbicide. Weed infestations at the STM site are much less severe than at the NWTC. Limited ground application of herbicides has been conducted at the STM since 1998. 
NREL promotes the sustainable management of its government-owned land by practicing environmentally sound, cost-effective landscaping practices. These practices reduce adverse impacts to the natural environment while providing essential shade and cooling for indoor and outdoor spaces, and a more aesthetically appealing appearance for the sites. This commitment is implemented by a sustainable landscape design and management program.

\subsubsection{Permitting}

There is no permitting applicable to vegetation management, although there is a state weed law that requires property owners to control certain species of invasive weeds (e.g., diffuse knapweed). For application of certain types of herbicides designated as "restricted use" by the EPA, a certified applicator must be used. The Federal Insecticide, Fungicide and Rodenticide Act (FIFRA) has a provision that makes it illegal to use a pesticide "in a manner inconsistent with its labeling." In other words, the label is the law. NREL strictly follows all pesticide label requirements.

\subsubsection{Activities}

NREL routinely practices IPM using various weed control methods, as described in the previous section. These are implemented during the normal course of site operation. In addition to the reclamation, off-road driving restrictions, and other weed control methods, ground applications of herbicides occurred at the NWTC in the spring of 2009. Very limited herbicide application was conducted on the STM site in the spring of 2009, focusing primarily on areas adjacent to roadways and buildings. The spraying was performed using a four-wheel drive vehicle. Primary target weeds were diffuse knapweed, leafy spurge, Canada thistle, common teasel, and hoary cress at the NWTC. At the STM, target weeds were mainly diffuse knapweed and Canada thistle with small areas of Dalmatian Toadflax.

In 2006, the weed management plans for the NWTC and STM were consolidated into an integrated weed management plan. Weed management activities used in 2009 were consistent with the integrated plan.

A master plant list for NREL was compiled in 2007. This list is based on information gathered during comprehensive vegetation surveys of the STM and NWTC completed in FY 2000 to FY 2002 by Plantae Consulting Services. No formal field work has been completed since the FY 2002 survey, but the list is updated as NREL EHS staff becomes aware of species not on the list (see Appendix C). However, planning activities for FY 2010, which began in 2009, included conducting a formal vegetation survey at both the South Table Mountain campus and the National Wind Technology Center. Contractor selection is schedule for early 2010.

\subsection{Wildlife}

\subsubsection{Program Management}

Wildlife habitat at the STM site is primarily grasslands, shrublands, and wetlands, while habitat at the NWTC is comprised of grasslands, woodlands, shrublands, and wetlands. Both sites provide vegetation types for a variety of wildlife species including birds, mammals, reptiles, and amphibians. The variety of vegetation types attracts species that may use the site as year-round habitat, for breeding only, during migration, or as winter habitat. Wildlife surveys were conducted on the STM site in 1987 and 2005, with follow-up verification surveys conducted in 1998 and 1999. Vegetation surveys were conducted at both the NWTC and STM, in 1999, and 2001, respectively. 


\subsubsection{NWTC Site}

The NWTC site is located in the transition zone between the Great Plains and the Rocky Mountains, resulting in habitat that contains elements from both mountain and prairie ecosystems. The DOE prepared a biological characterization inventory for the adjoining Rocky Flats site, including the NWTC, in 1992. At that time, 11 mammals and 8 species of reptiles or amphibians were documented. Representative species currently using the site include deer mouse, prairie vole, desert cottontail, coyote, mule deer, prairie rattlesnake, bullsnake, plains garter snake, and tiger salamander.

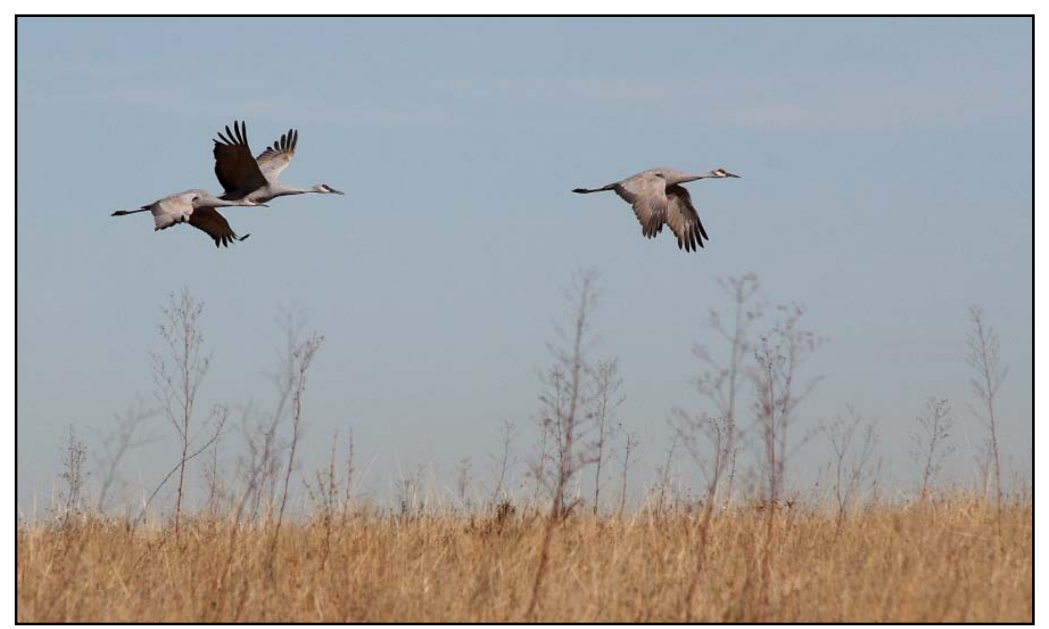

Figure 15. Sandhill cranes over the NWTC

\section{Credit: Bob Fiehweg}

Following the 1992 inventory, field surveys of avian use patterns at the NWTC were conducted in 1994 and 1995 to identify potential impacts of wind-turbine research on birds. Several species of raptors, including red-tailed hawk, American kestrel, and great-horned owl, were noted on the site, primarily resting and hunting, although a pair of kestrels were found nesting during the spring. Birds of prey of concern, such as eagles, generally fly in excess of 152 meters (500 ft.) over the site. No significant impacts to the birds from NREL activities were found

during these surveys.

In early 2001, a year-long monitoring project for birds and bats was initiated at the NWTC.

Standardized plot surveys were conducted to document the occurrence of songbirds and raptors on the site and adjacent undeveloped areas. This work also included systematic searches of turbines and meteorological towers to document avian mortality. The study was completed in July 2002. Notable findings of the study were as follows (Schmidt, E., et al., 2003):

- Abundances of individual raptor species on the NWTC site were similar to surrounding areas. However, the average number of species detected per count at the NWTC was nearly double that of surrounding areas in winter, the season when raptors are most abundant in the region. This difference is likely attributable to increased availability of perches at the site. Raptors flew and perched higher at the NWTC than in adjacent areas, again probably related to the wind turbines and other structures at the site.

- 46 bird species were counted on grassland plots during this study. Only 1 differed in abundance between the NWTC and adjacent areas; the horned lark was about 16 times more common off site. This difference is attributable to cattle on Boulder Open Space, creating low-stature grasslands preferred by this species.

- Bird abundance and variety on the undeveloped southern portion of the NWTC site were generally similar to the developed areas, except for the relative scarcity of raptors on the undeveloped site, which probably was due to a lack of perches. 
- The NWTC does not support a large diversity or abundance of bat species (possibly six species of bats use the site), but an area on the northwest side of the site, with trees close to a rocky outcrop, provides foraging and potential roosting habitat.

- No raptor carcasses were found during the 12-month survey of the NWTC except one American kestrel that had died before the study started. Bird mortality associated with the site appears to be minimal. Extrapolating from four passerine (songbird) carcasses found during the searches, estimated annual bird mortality attributable to NWTC activities was 24 individuals, all songbirds (Passeriformes). Most of these deaths were probably the result of collisions with support wires for the meteorological towers rather than the turbines themselves. No evidence was found of bat fatalities at the site.

\subsubsection{STM Site}

Similar to the NWTC, the STM site is located in the transition zone between the Great Plains and the Rocky Mountains, resulting in habitat that contains elements from both mountain and prairie ecosystems. The most recent site-wide wildlife survey of the STM site began in April 2004 and was completed in June 2005. The objectives of the survey were to update existing data in light of expanded development of both the site and the surrounding area, and to develop best management practices for future construction projects to maximize protection for site wildlife.

The survey included large and small mammals, predators, migratory birds and raptors, upland game birds, and invertebrates identified on an opportunistic basis (i.e., only as they are found during other surveys). A list of species observed at NREL is found in Appendix B; it includes the species observed during the year-long STM wildlife survey.

\subsubsection{Permitting}

Scientific collection licenses must be obtained from the

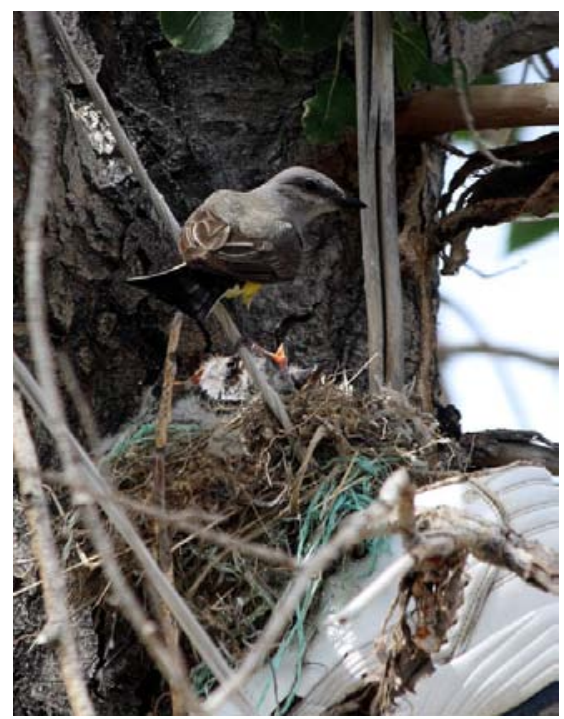

Figure 16. Western kingbirds nesting in an old shoe in the SERF parking lot

Credit: Bob Fiehweg Colorado Division of Wildlife for the small mammal trapping portion of the wildlife surveys. NREL has no other permitting requirements for this area of environmental management.

\subsubsection{Activities}

In compliance with the Migratory Bird Treaty Act, surveys for ground-nesting birds were completed prior to activities that could adversely affect these species. Surveys were conducted during the nesting season, from mid-April through mid-September. If an active nest was found, a buffer zone was set up around the nest to avoid impacts to nests during site activities.

\subsubsection{Migratory Birds and Raptors}

Many species of migratory birds were observed on the STM site, with many of these species potentially nesting on site. Additionally, the STM site provides important migration and winter habitat for migratory birds. For example, American tree sparrows are only observed on site during the winter and northern harriers have been observed hunting on site only in the fall and winter. Several species were only observed during the fall, including blue jay, downy woodpecker, red- 
breasted nuthatch, loggerhead shrike, and rock wren, suggesting that these species may use the STM site as a stopover during migration. Habitat for migrating birds is important, as some of these species may migrate as far south as Central and South America.

Several species of raptors were observed at the STM site and, two species were observed by both studies (1987 and 2004-2005) nesting on site; the red-tailed hawk and the American kestrel. Both of these species were observed hunting on-site during the 20042005 surveys, in addition to the Cooper's hawk, which is known to nest along nearby Clear Creek. The NREL STM site provides habitat and a prey base of small birds and small mammals for these raptor species. Species such as the Swainson's hawk migrate thousands of miles each year to winter in Argentina, and return to the western United States and Canada to breed. Areas such as the STM site may provide a prey source for the Swainson's hawk and other species during migration.

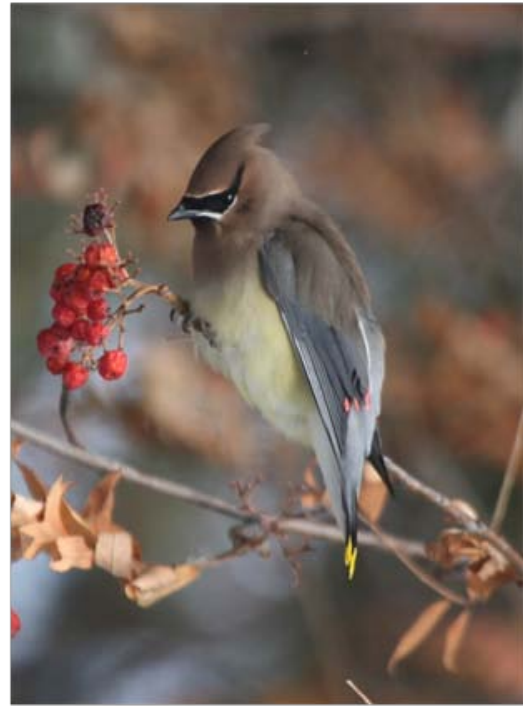

Figure 17. Cedar Waxwing at Building 7 in DWOP

Credit: Bob Fiehweg

\subsubsection{Summary Of 2009 Bird Surveys}

\section{Bird Surveys-STM}

Several ground-nesting bird surveys were conducted on the mesa top portion of the STM in advance of planned construction activities associated with the on-going construction of the Research Support Facility and new infrastructure projects. No active nests were found during any of these surveys, and construction activities were allowed to proceed.

\section{Bird Surveys-NWTC}

In 2009, ground-nesting bird surveys were done at the NWTC in areas slated for installation of new wind turbines. Construction activities were restricted in one area in the vicinity of the General Electric turbine after a fledgling vesper sparrow was found during one survey. Surveys were repeated until no young were found or adult defense behavior observed.

In November 2008, NREL developed a plan for the environmentally responsible removal of an estimated 50 prairie dogs from the western portion of the NWTC. A 1MW photovoltaic array is planned for the area currently colonized by the prairie dogs necessitating the removal. Biologists at NREL determined that the most cost-effective and environmentally responsible procedure included on-site re-location of the prairie dog colony to the northwest corner of the NWTC within one of the designated conservation management areas. By the end of 2008, a capture/re-location company was awarded a contract, and monitoring of current conditions was completed, and trenching in the relocation area was initiated. This project continued into CY2009 with the successful re-location of the colony. The colony was relocated to the northwest corner of the NWTC. Unfortunately, the colony was stricken by plague late in the year and all but a few individuals perished.

\subsubsection{Large Mammals}

Mule deer at the STM site have been observed in all habitat types. Mule deer were often observed in the amphitheater drainage or in the tall shrubland on the slope. When approached on the mesa top, the mule deer tended to move away from the disturbance and into the amphitheater drainage. 
The tall shrubland vegetation type may provide important hiding cover for this species. Spring pellet group surveys resulted in nearly double the amount of pellet groups and plots of the pellet groups were observed in than fall surveys. This may suggest that winter use of the STM site by deer may be higher than summer use or that deer utilize different habitats on site for these periods as affected by the availability of habitats and the location of survey plots, although the single year of data is not sufficient to draw conclusions regarding seasonal variation.

\subsubsection{Predators}

Coyotes are one of the most widespread and adaptable carnivores in North America and occur at all elevation levels and in all ecosystems in Colorado (Fitzgerald, et al. 1994). Lagomorphs (rabbits) and rodents are an important part of the coyote's diet, both of which are abundant on the STM site. Evidence of predation on cottontail rabbits (i.e., entrails and fur) was observed during site visits. Coyotes may breed on the STM site as two potential dens were observed in two of the site drainages.

\subsubsection{Small Mammals}

The deer mouse is the widest ranging and most common small mammal in North America (Fitzgerald, et al. 1994), and based on the 1987 and 2004-2005 survey data, it is also the most common small mammal on the NREL STM site. Deer mice can occur anyplace where cover occurs (Fitzgerald et al. 1994) and were observed in the four vegetation types sampled on the STM site. This species is a generalist and is known to exploit disturbed habitats.

Mexican woodrats and prairie voles have more restricted ranges at the STM site. Mexican woodrats are associated with rocky slopes and do not build dens away from rocky areas (Fitzgerald et al.

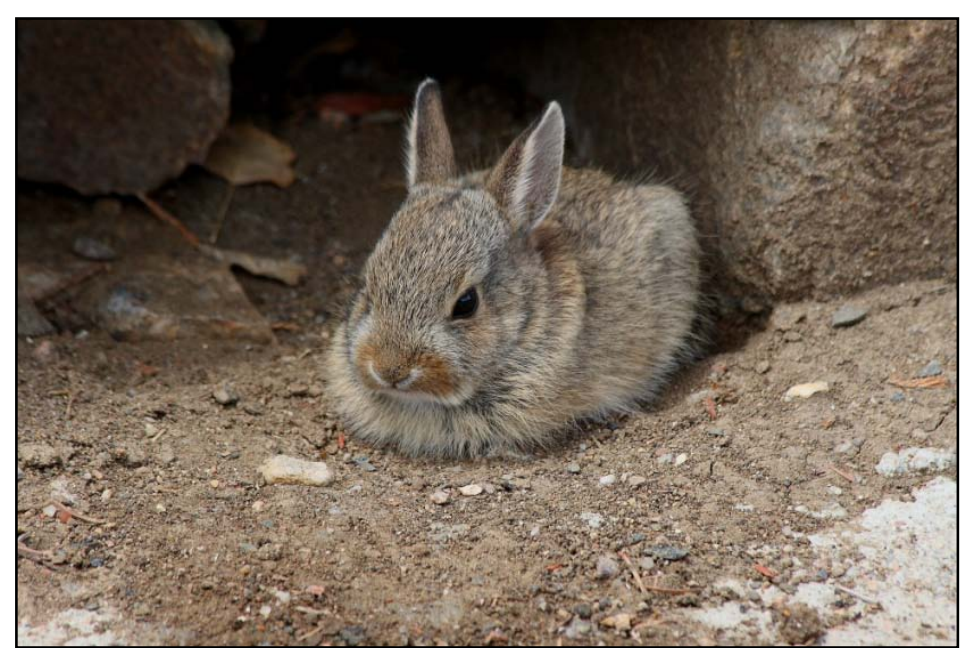

Figure 18. Young cottontail rabbit at STM Credit: Bob Fiehweg 1994); this habitat is limited at the STM site. Prairie voles are adapted to grasslands, constructing burrows and runway systems throughout the grassland, essentially limiting this species to the short grass and mixed grass vegetation types on the STM site.

All of these species are active throughout the year. Winter surveys (2004-2005) were conducted during a warm weather trend, which may have contributed to the highest number of small mammals caught compared to the three other surveys.

Black-tailed prairie dogs were not present at the NWTC when the wildlife survey was conducted, although the species was probably historically present. The colony that was relocated in 2008-2009 had reappeared in 2006 .

\subsubsection{Reptiles/Amphibians}

Several rattlesnakes were observed on the STM site, more often in rocky areas, but also in the grassland. A rattlesnake den may be present in the rocks near the top of the mesa slope north of the 
Visitors Center (near E-2-3) as four rattlesnakes were observed within a few feet of each other since 2007 , one in the open and three in a rock crevice. Hibernation generally occurs in rock outcrops, with this species usually active from mid-April through late-September (Hammerson 1999).

Although only four species of reptiles and one species of amphibian were opportunistically observed on the STM site, no specific survey methods were employed to identify or count these groups of wildlife.

To avoid or minimize disturbance to wildlife species on site, site-wide BMPs were developed as a result of this survey for consideration during ongoing normal site operations and future construction projects. The BMPs address migratory birds and raptors, mammals, all wildlife, and general site operations. They will be applied as appropriate to site activities and future site development.

\subsubsection{Planning Activities}

Planning began in 2009 for FY 2010 wildlife surveys at both the STM and MWTC. EHS began developing a scope of work that will generate results comparable to the previous wildlife surveys at these sites. In addition to the wildlife surveys, EHS began work on an avian monitoring project at the NWTC associated with the installation of the Siemens turbine. A contractor was hired to develop the methodology for an avian monitoring project at the NWTC. The plan was completed in December 2009 for implementation in 2010. The plan has four major components: 1. Fixed-point monitoring; 2. Transect surveys; 3. Mortality Surveys; and 4. Raptor Monitoring during spring migration.

\subsection{Endangered Species/Species of Concern}

\subsubsection{Program Management}

The Endangered Species Act provides for the designation and protection of wildlife, fish, and plant species that are in danger of extinction, and preserves the ecosystems on which these species depend. For the purposes of site wildlife surveys, a species of concern is defined as one protected under federal statutes, including the Endangered Species Act of 1973, as amended, the Bald Eagle Protection Act of 1940, as amended, and the Colorado Division of Wildlife list of endangered, threatened, and wildlife species of concern. Federal agencies are also required to abide by the Migratory Bird Treaty Act of 1918, as amended, but for this report, these species are not included as species of concern. For plant surveys, the Colorado Natural Heritage Program designation is also considered. Although this listing of rare species is not regulatory in nature, NREL uses it for management purposes.

The U.S. Fish and Wildlife Service has identified eight species listed in accordance with the Endangered Species Act as threatened, endangered, or a candidate for listing, that could potentially occur within the STM site project area. Of the State of Colorado's species of concern, eight species may potentially occur at the STM site. None of these were observed during any of the site surveys. However, based on existing habitat, four species could potentially be found at the site: American peregrine falcon, bald eagle, ferruginous hawk, and black-tailed prairie dog. Although a similar comparison of existing habitat at the NWTC to listed species has not been done to date, there is a colony of black-tailed prairie dogs present at the NWTC. The colony has been relocated to the northwestern portion of the site, in one of the designated conservation management areas.

The vegetation survey at NWTC, conducted between August 1999 and August 2000, identified a small area of xeric tallgrass (defined in the survey as mesic mixed grassland) prairie located in the 
southwest corner of the NWTC site. This natural community is listed as rare and imperiled by the Colorado Natural Heritage Program. This listing implies no legal designation, but is made primarily for management planning purposes. This xeric tallgrass prairie area has been designated by NREL as a conservation management area. Most of the conservation management areas on the NWTC are formally designated as areas on which building will not occur. However, as the xeric tallgrass prairie is in the active turbine testing area, it is not reasonable to preclude all development on portions of the site inhabited by this plant community. However, to the greatest extent possible, disturbance will be minimized on this biome.

The STM site vegetation survey completed in May 2002 found no rare or imperiled plant species on the site, but areas of mixed foothills shrublands (also called tall upland shrubland) were identified along the top of the mesa within the conservation easement area. That natural community is listed as rare and imperiled by the Colorado Natural Heritage program. It is within a designated conservation easement area where no development will occur except trails being established by Jefferson County Open Space (see Section 6.0 for a trails discussion).

As reported in Section 5.11.3, a site-wide wildlife survey of the STM site has recently been completed. No species observed on the STM site during the 1987 or the 2004-2005 wildlife surveys were present on either agency's list. However, golden eagles were incidentally observed on the STM site (outside of raptor surveys) and are protected under the Bald and Golden Eagle Protection Act. Golden eagles were observed flying over the site and may use the site for hunting. No golden eagle nests or nesting activities were observed on the STM site.

\subsubsection{Permitting}

NREL has no permitting requirements for this area of environmental management.

\subsubsection{Activities}

In 2009, the presence of the non-native Eurasian Collared Dove continued at NREL's STM. This invasive species, first spotted at STM in 2006 as a new avian species, had just begun to inhabit the Denver area at that time. The Colorado Division of Wildlife considers this species to be a threat to native avian species.

\subsubsection{Wetlands/Floodplains}

Management in this area is consistent with the following NREL Programs: Stormwater Pollution Prevention for Construction Activities at the STM (6-2.15), Stormwater Pollution Prevention for Construction Activities at the NWTC (6-2.16), and the Environmental Permitting and Notification (6-2.1).

Wetlands are defined by the USEPA and the Army Corps of Engineers (USACE) as areas that are inundated or saturated by surface or ground water at a frequency and duration sufficient to support, and that under normal circumstances do support, a prevalence of vegetation typically adapted for life in saturated soil conditions. Wetlands generally include swamps, marshes, bogs, and similar areas. Wetlands became regulated in 1972 when, under the Clean Water Act, the definition of waters of the U.S. was expanded from only those waters capable of supporting interstate or foreign commerce as defined under the Rivers and Harbors Act of 1899, to waters that also include tributaries to navigable waters, interstate wetlands, wetlands which could affect interstate or foreign commerce, and wetlands adjacent to other waters of the U.S. 
Wetlands that meet hydric soils, vegetation and hydrologic criteria, are protected under the Clean Water Act Section 404, which is administered by the USACE, with program oversight provided by the USEPA. Areas that do not meet the criteria established by the USACE may perform wetland functions and serve as valuable ecologic components, but do not fall within the jurisdiction of the USACE and are therefore not protected or regulated under Section 404 of the Clean Water Act. In early 2009, the USACE was invited to the STM site to determine whether the observed wetlands and drainages that cross the STM site are considered jurisdictional and therefore regulated by the USACE. The following six drainages were identified:

- East Drainage (east of the Visitors Center)

- Middle Drainage (originating upstream of the amphitheater and flowing between the FTLB and the SERF)

- Middle West Drainage (above the Thermal Test Facility (TTF)

- West Drainage (near the west entrance gate)

- Jefferson County Easement Drainage (south of Denver West Parkway and east of the "lower 25 ")

- Roadside drainages and trickle channel drainages (constructed drainages generally on the north side of Denver West Parkway).

Following their site visit, the USACE issued a letter stating that all drainages examined were considered upland swales vegetated with upland vegetation and are, consequently, not regulated/protected by the USACE. They provided a jurisdictional determination (JD) documenting their finding. The USACE JD, valid for five years (through April 27, 2014), enables NREL to perform work in the upland swales/wetlands without a USACE permit. While the USACE did not consider wetlands located at STM to be jurisdictional, NREL regards them as ecologically functional wetlands. Vegetation surveys in 2000 and 2001 at STM and the NWTC identified wetland areas totaling $0.3 \mathrm{ha}(0.75 \mathrm{ac})$ and $0.4 \mathrm{ha}(1 \mathrm{ac})$, respectively. These areas will continue to be protected for the benefits they provide which include water quality filtration, attenuation of stormwater flows and habitat for site fauna.

\subsection{Cultural Resources}

\subsubsection{Program Management}

Cultural resources are protected under Section 106 of the National Historic Preservation Act (NHPA) of 1966, as amended. Significant cultural resources are either eligible for, or listed in, the National Register.

Cultural resources are defined as any prehistoric or historic district, site, building, structure, or object considered important to a culture, subculture, or community for scientific, traditional, religious, or any other reason. Cultural resources can be divided into three major categories:

- Prehistoric and historic archaeological resources

- Architectural resources

- Traditional cultural resources.

Prehistoric and historic archaeological resources are locations where human activity measurably altered the earth or left deposits of physical remains (e.g., arrowheads, bottles). Prehistoric resources that predate the advent of written records in a region range from a scatter composed of a few artifacts to village sites and rock art. Historic resources may include campsites, roads, fences, trails, dumps, battlegrounds, mines, and a variety of other features. 
Architectural resources include standing buildings, dams, canals, bridges, and other structures of historic or aesthetic significance. Architectural resources generally must be more than 50 years old to be considered for protection under existing cultural resource laws. However, more recent structures, such as Cold War facilities, may warrant protection if they manifest the potential to gain significance in the future.

A traditional cultural resource can be defined as a property that is eligible for inclusion in the National Register because of its association with cultural practices or beliefs of a living community that are rooted in the community's history, and are important in maintaining the continuing cultural identity of the community. Traditional resources may include archaeological resources, buildings, neighborhoods, prominent topographic features, habitats, plants, animals, traditional culture.

\subsubsection{Site Surveys}

Three formal surveys of historic and cultural resources have been performed on the STM site. These surveys were completed in 1980, 1987, and 2003. Two additional surveys of the Camp George West district involving the STM site have also been conducted.

As a result of these STM surveys, three historical sites were recognized as significant cultural resources that should be preserved. These sites include an open-air amphitheater (Figure 5.13), a stone bridge spanning a natural drainage channel adjacent to the amphitheater, and a stone and concrete ammunition bunker below the amphitheater site (Figure 5.14). The three structures were constructed during the Works Progress Administration era in the 1930s. Through NREL's efforts, these sites have been added to the National Register, with the amphitheater and stone footbridge listed together as a single site. NREL also participated in an interagency survey of STM and Camp George West to identify historic structures and sites eligible for nomination to the National Register. Figure 1.7 provides an aerial view of the amphitheater.

The Camp George West Historic District, also listed on the National Register, includes the 25-acre parcel of NREL's site, south of the DWOP. Two types of historic archaeological resources (firing range lines and a low rock wall) have been identified on this parcel. These resources have been determined to contribute to the National Register eligibility of the Camp George West Historic District.

The Camp George West Historic District overlaps the NREL STM property by 25 acres. Two contributing resources occur within those 25 acres. Contributing resources are those features within a historic district that contribute to the district's overall eligibility for the National Register.

A 2003 cultural resource survey was conducted of the 25-acre parcel south of Denver West Parkway on the STM site. The survey confirmed the existence of the contributing features to the Camp George West Historic District occurring within the 25-acre parcel. The contributing resources are:

- Two firing lines located on the 25 acres. There are also firing lines located south of the NREL property on land owned by Jefferson County Open Space and proposed for development as the Camp George West Park.

- Portions of a low rock wall are also present on the 25 acres. There is also a rock wall located south of the NREL property. 
DOE consulted with the State Historic Preservation Office (SHPO) regarding the significant resources located on the 25 acres. DOE and the SHPO subsequently entered into a Memorandum of Agreement where DOE agreed to perform further surveys to fully document the resources on the 25 acres prior to any development of the parcel.

In 2005, DOE-GO and NREL conducted documentation of the Camp George West firing range lines and low rock walls, which contribute to the Camp George West Historic District's eligibility to the National Register. The documentation resulted in Level II documentation from the Historic American Buildings Survey (HABS) and the Historic American Engineering Record (HAER) that consisted of mapping, photographs, and detailed description of the resources. The documentation was submitted using archival quality materials to the SHPO in late 2005.

In January 2006, the Camp George West Level II HABS/HAER documentation (originally dated August 2005) was revised to include field drawings of the "low rock wall" as requested by the Colorado SHPO. This was the final report submitted to the SHPO. It is on file with the Colorado SHPO and also at the DOE-GO and NREL offices.

Also in CY2006, a site survey for cultural resources was conducted in support of NREL/DOE EAs for the first of three site development projects (RFHP, and two potential solar field sites). The RFHP EA was completed in early summer 2007.

An archaeological survey of the NWTC site was conducted in support of the 1996 environmental assessment to supplement previous surveys so there were no gaps in cultural surveys on the site. No significant historical or archaeological resources were identified. However, the wooded ridge area on the west portion of the site was identified as a location with potential for cultural resources, so further testing or observation during excavation would be done should there be any future need for work in the utility corridor in the vicinity of the ridge.

\subsubsection{Permitting and Requirements}

NREL has no permitting requirements for this area of environmental management. In order to comply with cultural resource protection requirements, NREL instructs construction contractors at their site orientation that in the event they discover any evidence of cultural resources during ground disturbing activities at the STM or NWTC sites, they are to stop all work in the vicinity until a qualified archaeologist evaluates the significance of the find.

\subsubsection{Activities}

In 2009, construction activities continued on the Research Support Facility near the Site Entrance Building. During the preliminary excavations, a few items were unearthed that were reviewed under the Cultural Resource Management procedure; while of interest, none were found to be of unique value.

\subsection{National Environmental Policy Act (NEPA)}

\subsubsection{Program Management}

Management in this area is consistent with NREL's NEPA Implementation Program (6-2.2). As a federal agency, DOE is required to comply with NEPA by evaluating the potential for environmental impacts prior to conducting its activities. The Council of Environmental Quality (CEQ) issues regulations for compliance with the Act. DOE has also issued implementing 
regulations at $10 \mathrm{CFR}$ that complement the CEQ requirements. DOE has written a site-wide environmental assessment (EA) for its activity at the STM Site and DWOP, and separate EAs for the NWTC and JSF activities.

NREL has established procedures, with the approval of the DOE-GO, to assist DOE in meeting their NEPA obligation. Proposed activities that will be conducted at NREL's five sites are evaluated for their potential environmental effects using the appropriate level of NEPA review, in conjunction with DOE-GO.

The NREL NEPA Handbook has been prepared to provide NREL project managers and procurement specialists with guidance on implementing the NEPA procedures, and training is provided to staff, as appropriate.

\subsubsection{Permitting}

NREL has no permitting requirements under NEPA.

\subsubsection{Activities}

During 2009, EHS completed numerous NEPA reviews of both onsite and offsite activities through completion of NEPA Worksheets and NREL environmental checklists. As outlined in NREL's NEPA implementation procedures, these reviews were coordinated among NREL project managers, subcontracting staff, the NREL NEPA coordinator, and the DOE-GO NEPA Compliance Officer. NEPA requirements were also coordinated with future program planning (e.g., development of NREL's 2007 Grand Buildout Infrastructure Design) through interaction between NREL's EHS Office director and NREL's technology program and project managers. Requirements were also coordinated through participation in the NREL management annual planning process, Environmental Management System implementation, and other reviews of proposed projects for the upcoming FY 2010.

In 2009, NREL completed the EA process for the second STM site-wide EA supplement (DOE/EA 1441-S-2) to address proposed site development projects, including the Energy Systems Integration Facility (ESIF), Site Infrastructure Improvements (Phase II), South Site Entrance from South Golden Road, Expansion of the Waste Handling Facility, and Expansion of the Visitors Center. Also in 2009, planning began for extensive vegetation and wildlife surveys at the STM and NWTC sites in support of revisions to the site-wide EAs for each location.

In 2008, DOE issued the Final Supplement to Final Site-Wide Environmental Assessment of the NREL STM Complex (DOE/EA 1440-S-1), which received a Finding of No Significant Impact (FONSI). As a condition of the FONSI, DOE issued a Mitigation Action Plan (MAP) to address a DOE determination that there are potential environmental impacts from these projects that require mitigation to assure that the impacts do not become significant. The MAP identified steps that would be taken to reduce traffic impacts resulting from the transfer of approximately 800 employees to the new Research Support Facility. These steps, and their status, are described in Section 4.4.1, above. The MAP also requires that a report of the implementation and effectiveness of the STM mitigation measures be published in the Annual Site Environmental Report (this document). The report is to be published after occupation of the RSF, anticipated to be June 2010. 


\subsection{Radiological Program}

\subsubsection{Program Management}

Management in this area is consistent with the following NREL programs: Air Quality Protection (62.5) and Radiation Safety (6-4.5). All radioactive material at NREL facilities is handled according to NREL's Radiation Safety Program. Elements of the program include a Radiation Safety Committee, a Radiation Safety Lab-Level Procedure, safe operating procedures, safe work permits, radiological control areas and postings, monitoring, training (Rad Worker 1: Radiation Equipment Safety and Rad Worker 1: Radiation Materials Safety), and purchasing controls for radioactive materials.

There are no nuclear operations at NREL sites. All of NREL's radiation sources are used/stored in facilities located on the STM site. These include three X-ray diffraction machines at the SERF and one at the FTLB. In addition, one laboratory at the FTLB, on the STM site, occasionally uses small quantities of radioisotopes for biological labeling. All x-ray generating machines are inspected annually. A state-licensed surveyor inspects and certifies the x-ray machines and audits NREL's program for radiation safety in connection with operating the machines every other year. NREL's radiation safety officer conducts the inspections in alternating years.

Monitoring of equipment and facilities for removable contamination is performed in the laboratory where radioisotopes are used. Wipe tests are performed on any laboratory surfaces that could have become contaminated by the radioisotope work at least monthly and more frequently if needed. These wipes are analyzed using a scintillation counter.

DOE Order 5400.5, "Radiation Protection of the Public and the Environment," established radiation emission limits for DOE facilities. Such emissions are also regulated by Section 112 of the Clean Air Act as implemented by 40 CFR 61, Subpart H, promulgated by the EPA. 40 CFR 61 established National Emission Standards for Hazardous Air Pollutants (NESHAPs), and, more specifically, Subpart H, sets such standards for radiological materials, known as Rad NESHAPs. DOE facilities, including NREL, must annually demonstrate compliance with the Rad NESHAP, which limits emissions to amounts that would prevent any member of the public from receiving an effective dose of 10 millirem (mrem) per year or greater. No radioactive air-emission monitoring is conducted at NREL because of the extremely low usage of radioactive material. Therefore, NREL demonstrates compliance with the Rad NESHAPs in 40 CFR 61, Subpart H, by utilizing the EPA's COMPLY computer model to determine the effective dose equivalent to the public.

In 2009, NREL reported that, using the COMPLY model, the laboratory's effective dose equivalent to public was $0.027 \mathrm{mrem} /$ year, well below the Rad NESHAP limit.

All radioactive waste generated during NREL activities is classified as low-level waste. Waste from the STM site is temporarily stored at the Waste Handling Facility (WHF) until disposal is arranged at an offsite facility permitted to accept low-level radioactive waste.

\subsubsection{Permitting}

NREL does not have a radioactive materials license from the State of Colorado, as the laboratory is currently under DOE jurisdiction for radioactive materials handling. 


\section{Conservation Easement Lands}

In 1999, DOE granted a conservation easement for 177 acres of the STM site to Jefferson County. The purpose of the conservation easement is to preserve the natural character of the property, including its visual, biological, and recreational resources, especially in relation to the changing land uses adjacent to the NREL site and within the region.

The goals of the easement are to:

- Retain, preserve, and protect natural, scenic, ecological, and historical aspects of the conservation easement property

- Protect the ecosystem of the STM area and the sustainable habitat for diverse vegetation, birds, and terrestrial animals

- Ensure the scenic and biological integration with adjoining open-space land

- Prevent further industrial, commercial, or residential development of the conservation easement property

- Preserve the conservation easement property as natural open space.

A baseline inventory of the property was prepared in June 1999 to document the current condition of the easement property and to assess the conservation value of the property (Department of Energy, Golden Field Office, 1999). The baseline inventory includes a description of the geographical setting and adjacent property owners, access and use of the property by the public, and a description of the existing environmental conditions of the property (geology, hydrology, vegetation, wildlife, and cultural resources).

Jefferson County began the development of the South Table Mountain Management Plan in 2000, with a final version approved by the Jefferson County Open Space Advisory Committee and the Board of County Commissioners in 2004.

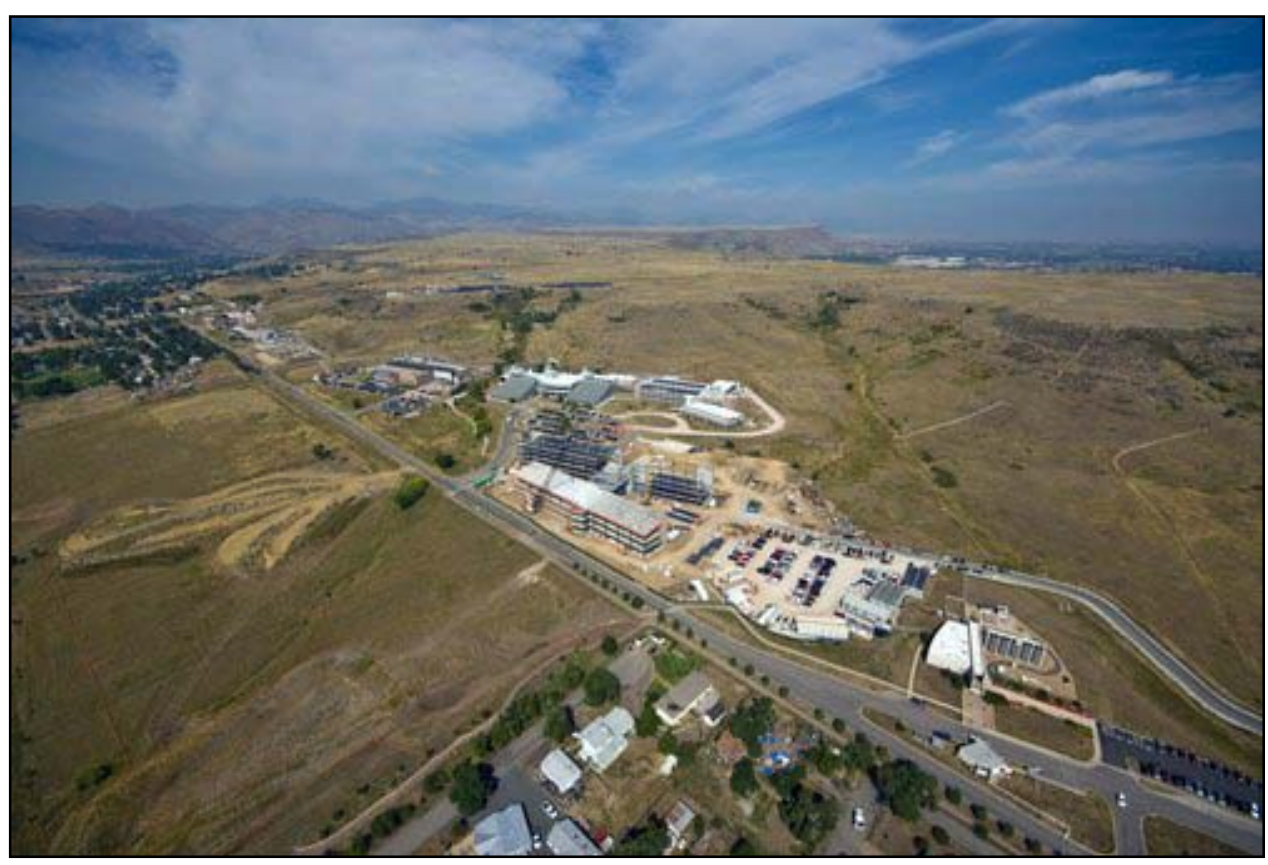

Figure 19. South Table Mountain conservation easement area

Credit: Bob Fiehweg 


\subsection{Property Assessment}

During 2009, there was no NREL activity on the conservation easement property having the potential to degrade the environmental condition of the property. Jefferson County Open Space conducted a site inspection during the summer of 2004; no degraded conditions or other environmental issues were found.

Jefferson County Open Space has the responsibility to establish and maintain formal trails on the conservation easement property. The trail plan calls for establishing trails in phases. The first phase began in 2004, with Jefferson County Open Space installing two trails from Denver West Parkway (near the NREL Site Entrance) to the mesa top. Routine trail maintenance occurred in CY2009. The access trail along the NREL entrance road was improved in 2008 and again in 2009 to accommodate changes necessitated by construction activities. 


\section{Contacts for Feedback or More Information}

We welcome your feedback and suggestions on this report and on NREL's efforts at sustainability and environmental stewardship. To provide comments or to obtain additional information about NREL's environmental and sustainability programs, please contact:

Maureen Jordan

Director, EHS

maureen.jordan@nrel.gov

303-275-3248
John Eickhoff

Senior Environmental Scientist

john.eickhoff@nrel.gov

303-275-3217

National Renewable Energy Laboratory

1617 Cole Boulevard, Golden, Colorado 80401-3393

303-275-3000 - www.nrel.gov

Operated for the U.S. Department of Energy

Office of Energy Efficiency and Renewable Energy

by the Alliance for Sustainable Energy, LLC

NREL- August 2009 


\section{References}

Armstrong, D.; Bock, C.; Piaggio, T.; Schmidt, E. (2001). NWTC Site wide Bat and Avian Impact Study Plan. May 1, 2001-July 31, 2002.

EG\&G Rocky Flats, Inc. (1992). Rocky Flats Plant Site Environmental Report, January Through December 1992. Golden, Colorado.

Felsburg Holt \& Ullevig (2007). National Renewable Energy Laboratory South Table Mountain Facility Traffic Impact Study Update. Centennial, Colorado.

Handex of Colorado, Inc. (1997). Groundwater Monitoring Report, South Table Mountain Site. Golden, Colorado.

National Renewable Energy Laboratory (Draft). ES\&H Program Number 6-2.12,

Weed Management Program, STM Site. Golden, Colorado.

National Renewable Energy Laboratory (1997). National Renewable Energy Laboratory Environmental Report for 1995 and 1996. Golden, Colorado.

National Renewable Energy Laboratory (1999a). National Renewable Energy Laboratory Five-Year Plan, 2000-2004. Golden, Colorado.

National Renewable Energy Laboratory (1999b). NREL Policy Number 6-2, Environmental Management. Golden, Colorado.

National Renewable Energy Laboratory (1999c). NREL Policy Number 6-6, Risk Assessment. Golden, Colorado.

National Renewable Energy Laboratory (2009a). Fiscal Year 2009 Laboratory Directed Research and Development (LDRD) Program.. Golden, Colorado.

National Renewable Energy Laboratory (2009b). FY 2009 National Renewable Energy Laboratory Annual Report: A Year of Energy Transformation. Golden, Colorado.

National Renewable Energy Laboratory (2009c). Sustainability Report 2009. Golden, Colorado.

Plantae Consulting Services (2000). Vegetation Survey, NREL National Wind Technology Center. Boulder, Colorado.

Plantae Consulting Services (2002). Vegetation Survey, NREL South Table Mountain Site. Boulder, Colorado

Rust Environment \& Infrastructure, Inc. (1993). Water Quality Monitoring, National Wind Technology Center. Englewood, Colorado. 
Rust Environment \& Infrastructure, Inc. (1994). Final Report, Baseline Surface Water Monitoring Program: 1993. Englewood, Colorado.

Rust Environment \& Infrastructure, Inc. (1995a). Report, Wastewater Monitoring Program, Fourth Quarter, 1994 and Annual Report. Englewood, Colorado.

Rust Environment \& Infrastructure, Inc. (1995b). Final Report, Ground Water Monitoring, Third Quarter, 1994 and Fourth Annual Report, South Table Mountain Site. Englewood, Colorado.

Schmidt, E.; Piaggio, A.J.; Bock, C.E.; Armstrong, D.M. (January 2003). National Wind Technology Center Site Environmental Assessment: Bird and Bat Use and Fatalities - Final Report. University of Colorado, Boulder, Colorado.

Science Applications International Corporation (2005). Wildlife Survey (Including Migratory Birds and Raptors) at the National Renewable Energy Laboratory South Table Mountain Site, Golden, Colorado. Lakewood, Colorado.

U.S. Department of Energy (1993). Site wide Environmental Assessment for the National Renewable Energy Laboratory, Golden, Colorado. DOE/EA-0850.

U.S. Department of Energy (1998). Environmental Assessment, Right-of-Way Easement For Public Service Company of Colorado at the South Table Mountain Site, Golden, Colorado. DOE/EA-1254.

U.S. Department of Energy (2002). Site-Wide Environmental Assessment of National Renewable Energy Laboratory’s National Wind Technology Center. DOE/EA 1378.

U.S. Department of Energy (2003). Site-Wide Environmental Assessment of the National Renewable Energy Laboratory's South Table Mountain Complex. DOE/EA 1440.

U.S. Department of Energy (2007). Final Environmental Assessment of Three Site Development Projects at the National Renewable Energy Laboratory South Table Mountain Site. DOE/EA 1573.

U.S. Department of Energy (2009). Annual Energy Outlook 2009. DOE/EIA 0380(2009).

U.S. Department of Energy, Golden Field Office (1999). National Renewable Energy Laboratory (NREL) Site Conservation Easement Baseline Inventory. Golden, Colorado.

Western Ecosystems Technology, Inc. (2009) Study Plan: Monitoring Avian Use and Mortality at the National Wind Technology Center. 


\section{Appendices}

Appendix A - Summary of NREL Environmental Permits, Registrations, Notifications Appendix B - Wildlife Species Observed on the STM Site 


\subsection{Appendix A: Summary of NREL Environmental Permits, Registrations, Notifications}

Table 6. Summary of NREL Environmental Permits, Registrations, Notifications

\begin{tabular}{|c|c|c|c|c|c|c|}
\hline Category & $\begin{array}{l}\text { Permit or } \\
\text { Registration } \\
\text { Number }\end{array}$ & $\begin{array}{c}\text { Permit or } \\
\text { Reg. Holder }\end{array}$ & Permit Type & Permit Description & Issuing Agency & Status \\
\hline Permit & 04JE1442L & DOE & Air & $\begin{array}{l}\text { Air Emission Permit for Land } \\
\text { Development (fugitive dust } \\
\text { from construction activities) }\end{array}$ & $\begin{array}{l}\text { Colorado Dept. of } \\
\text { Public Health and } \\
\text { Environment }\end{array}$ & Expired \\
\hline Permit & 04JE1443L & DOE & Air & $\begin{array}{l}\text { Air Emission Permit for Land } \\
\text { Development (fugitive dust } \\
\text { from construction activities) }\end{array}$ & $\begin{array}{l}\text { Colorado Dept. of } \\
\text { Public Health and } \\
\text { Environment }\end{array}$ & Expired \\
\hline Permit & 99JE0400 & NREL/DOE & Air & TCPDU air emissions & $\begin{array}{l}\text { Colorado Dept. of } \\
\text { Public Health and } \\
\text { Environment }\end{array}$ & Active \\
\hline Permit & 07JE0277 & DOE & Air & $\begin{array}{l}\text { Stationary Source } \\
\text { Construction (RFHP) }\end{array}$ & $\begin{array}{l}\text { Colorado Dept. of } \\
\text { Public Health and } \\
\text { Environment }\end{array}$ & Active \\
\hline Permit & 08JE0889L & DOE & Air & $\begin{array}{l}\text { Air Emission Permit for Land } \\
\text { Development (fugitive dust } \\
\text { from construction activities) }\end{array}$ & $\begin{array}{l}\text { Colorado Dept. of } \\
\text { Public Health and } \\
\text { Environment }\end{array}$ & Active \\
\hline Permit & & DOE & Air & $\begin{array}{l}\text { Air Emission Permit, Air } \\
\text { Pollution Emission Notice } \\
\text { (APEN) }\end{array}$ & $\begin{array}{l}\text { Colorado Dept. of } \\
\text { Public Health and } \\
\text { Environment }\end{array}$ & $\begin{array}{c}\text { Active, Self- } \\
\text { Certification } \\
\text { documentation } \\
\text { submitted - } \\
\text { awaiting } \\
\text { APEN } \\
\text { Issuance }\end{array}$ \\
\hline Permit & 10JE1400 & DOE & Air & $\begin{array}{l}\text { Air Emission Permit, Air } \\
\text { Pollution Emission Notice } \\
\text { (APEN) }\end{array}$ & $\begin{array}{l}\text { Colorado Dept. of } \\
\text { Public Health and } \\
\text { Environment }\end{array}$ & Active \\
\hline Permit & 10JE1630 & DOE & Air & Air Emission Permit, Air & Colorado Dept. of & Pending \\
\hline
\end{tabular}




\begin{tabular}{|c|c|c|c|c|c|c|}
\hline Category & $\begin{array}{l}\text { Permit or } \\
\text { Registration } \\
\text { Number }\end{array}$ & $\begin{array}{c}\text { Permit or } \\
\text { Reg. Holder }\end{array}$ & Permit Type & Permit Description & Issuing Agency & Status \\
\hline & & & & $\begin{array}{l}\text { Pollution Emission Notice } \\
\text { (APEN) }\end{array}$ & $\begin{array}{l}\text { Public Health and } \\
\text { Environment }\end{array}$ & \\
\hline Permit & 10JE1712 & DOE & Air & $\begin{array}{l}\text { Air Emission Permit, Air } \\
\text { Pollution Emission Notice } \\
\text { (APEN) }\end{array}$ & $\begin{array}{l}\text { Colorado Dept. of } \\
\text { Public Health and } \\
\text { Environment }\end{array}$ & $\begin{array}{c}\text { Active, APEN } \\
\text { application } \\
\text { submitted } \\
6 / 23 / 2010, \\
\text { application in } \\
\text { process }\end{array}$ \\
\hline $\begin{array}{l}\text { Notification } \\
\text { and } \\
\text { Registration }\end{array}$ & 001 and 002 & DOE & $\begin{array}{l}\text { AIR: OZONE } \\
\text { DEPLETING } \\
\text { SUBSTANC } \\
\text { ES }\end{array}$ & $\begin{array}{l}\text { Registration of stationary } \\
\text { appliances (2 SERF chillers) }\end{array}$ & $\begin{array}{l}\text { Colorado Dept. of } \\
\text { Public Health and } \\
\text { Environment }\end{array}$ & Active \\
\hline $\begin{array}{l}\text { Notification } \\
\text { and } \\
\text { Registration }\end{array}$ & $\mathrm{N} / \mathrm{A}$ & DOE & $\begin{array}{l}\text { AIR: OZONE } \\
\text { DEPLETING } \\
\text { SUBSTANC } \\
\text { ES }\end{array}$ & Facility Notification - CFCs & $\begin{array}{l}\text { Colorado Dept. of } \\
\text { Public Health and } \\
\text { Environment }\end{array}$ & Active \\
\hline $\begin{array}{l}\text { Notification } \\
\quad \text { and } \\
\text { Registration }\end{array}$ & 1 & $\mathrm{DOE}$ & $\begin{array}{l}\text { AIR: OZONE } \\
\text { DEPLETING } \\
\text { SUBSTANC } \\
\text { ES }\end{array}$ & $\begin{array}{l}\text { Registration of stationary } \\
\text { appliance (chiller in DWOP) }\end{array}$ & $\begin{array}{l}\text { Colorado Dept. of } \\
\text { Public Health and } \\
\text { Environment }\end{array}$ & Active \\
\hline Permit & AFP-CO-00255 & DOE & Alcohol & Alcohol Producer's Permit & $\begin{array}{l}\text { U. S. Department of } \\
\text { the Treasury }\end{array}$ & $\begin{array}{l}\text { Annual } \\
\text { renewal due } \\
\text { July } 1\end{array}$ \\
\hline Permit & TF-CO-0331 & $\mathrm{DOE}$ & Alcohol & $\begin{array}{l}\text { Industrial Alcohol User } \\
\text { Permit }\end{array}$ & $\begin{array}{l}\text { U. S. Department of } \\
\text { the Treasury }\end{array}$ & $\begin{array}{l}\text { Annual } \\
\text { renewal due } \\
\text { July } 1\end{array}$ \\
\hline $\begin{array}{l}\text { Notification } \\
\quad \text { and } \\
\text { Registration }\end{array}$ & $2873-1$ & $\begin{array}{l}\text { Alliance for } \\
\text { Sustainable } \\
\text { Energy, LLC }\end{array}$ & AST & $\begin{array}{l}\text { Annual registration for AST } \\
\text { greater than } 660 \text { gallons }\end{array}$ & $\begin{array}{l}\text { Colorado } \\
\text { Department of } \\
\text { Labor and } \\
\text { Employment }\end{array}$ & In Service \\
\hline
\end{tabular}




\begin{tabular}{|c|c|c|c|c|c|c|}
\hline Category & $\begin{array}{l}\text { Permit or } \\
\text { Registration } \\
\text { Number }\end{array}$ & $\begin{array}{c}\text { Permit or } \\
\text { Reg. Holder }\end{array}$ & Permit Type & Permit Description & Issuing Agency & Status \\
\hline $\begin{array}{l}\text { Notification } \\
\text { and } \\
\text { Registration }\end{array}$ & $2873-2$ & $\begin{array}{l}\text { Alliance for } \\
\text { Sustainable } \\
\text { Energy, LLC }\end{array}$ & AST & $\begin{array}{l}\text { Annual registration for AST } \\
\text { greater than } 660 \text { gallons }\end{array}$ & $\begin{array}{l}\text { Colorado } \\
\text { Department of } \\
\text { Labor and } \\
\text { Employment }\end{array}$ & In Service \\
\hline Permit & P15-07-00003 & NREL & $\begin{array}{l}\text { BioSafety } \\
\text { Permit }\end{array}$ & Sugarcane Bagasse & $\begin{array}{l}\text { U. S. Department of } \\
\text { Agriculture }\end{array}$ & expired \\
\hline Permit & PDEP-07-00222 & NREL & $\begin{array}{l}\text { BioSafety } \\
\text { Permit }\end{array}$ & Wheat Streams & $\begin{array}{l}\text { U. S. Department of } \\
\text { Agriculture }\end{array}$ & expired \\
\hline Permit & PDEP-06-00178 & NREL & $\begin{array}{l}\text { BioSafety } \\
\text { Permit }\end{array}$ & Oryza sativa leaves and stems & $\begin{array}{l}\text { U. S. Department of } \\
\text { Agriculture }\end{array}$ & expired \\
\hline $\begin{array}{l}\text { Notification } \\
\text { and } \\
\text { Registration }\end{array}$ & $\begin{array}{l}\text { PWSID Number } \\
\text { CO0230860 }\end{array}$ & DOE & $\begin{array}{l}\text { DRINKING } \\
\text { WATER }\end{array}$ & $\begin{array}{l}\text { Non-community Supply of } \\
\text { hauled water from a surface } \\
\text { water source }\end{array}$ & $\begin{array}{l}\text { Colorado Dept. of } \\
\text { Public Health and } \\
\text { Environment }\end{array}$ & active \\
\hline Permit & 37232 & SERI & $\begin{array}{c}\text { GW } \\
\text { Monitoring } \\
\text { Well } \\
\end{array}$ & $\begin{array}{l}\text { Permit to Construct a Well } \\
(\mathrm{MW}-1)\end{array}$ & $\begin{array}{l}\text { Colorado } \\
\text { Department of } \\
\text { Natural Resources } \\
\end{array}$ & active \\
\hline Permit & 37229 & SERI & $\begin{array}{c}\text { GW } \\
\text { Monitoring } \\
\text { Well } \\
\end{array}$ & $\begin{array}{l}\text { Permit to Construct a Well } \\
(\mathrm{MW}-2)\end{array}$ & $\begin{array}{l}\text { Colorado } \\
\text { Department of } \\
\text { Natural Resources } \\
\end{array}$ & active \\
\hline Permit & 37228 & SERI & $\begin{array}{c}\text { GW } \\
\text { Monitoring } \\
\text { Well }\end{array}$ & $\begin{array}{l}\text { Permit to Construct a Well } \\
(\mathrm{MW}-3)\end{array}$ & $\begin{array}{l}\text { Colorado } \\
\text { Department of } \\
\text { Natural Resources } \\
\end{array}$ & active \\
\hline Permit & 37231 & SERI & $\begin{array}{c}\text { GW } \\
\text { Monitoring } \\
\text { Well }\end{array}$ & $\begin{array}{l}\text { Permit to Construct a Well } \\
(\mathrm{MW}-4)\end{array}$ & $\begin{array}{l}\text { Colorado } \\
\text { Department of } \\
\text { Natural Resources }\end{array}$ & active \\
\hline Permit & 37230 & SERI & $\begin{array}{c}\text { GW } \\
\text { Monitoring } \\
\text { Well }\end{array}$ & $\begin{array}{l}\text { Permit to Construct a Well } \\
(\mathrm{MW}-5)\end{array}$ & $\begin{array}{l}\text { Colorado } \\
\text { Department of } \\
\text { Natural Resources } \\
\end{array}$ & active \\
\hline Permit & 214960 & NREL/DOE & $\begin{array}{c}\mathrm{GW} \\
\text { Monitoring }\end{array}$ & $\begin{array}{l}\text { Permit to Construct a Well } \\
(\mathrm{MW}-11)\end{array}$ & $\begin{array}{l}\text { Colorado } \\
\text { Department of }\end{array}$ & inactive \\
\hline
\end{tabular}




\begin{tabular}{|c|c|c|c|c|c|c|}
\hline Category & $\begin{array}{c}\text { Permit or } \\
\text { Registration } \\
\text { Number } \\
\end{array}$ & $\begin{array}{c}\text { Permit or } \\
\text { Reg. Holder }\end{array}$ & Permit Type & Permit Description & Issuing Agency & Status \\
\hline & & & Well & & Natural Resources & \\
\hline Permit & 214961 & NREL/DOE & $\begin{array}{c}\text { GW } \\
\text { Monitoring } \\
\text { Well }\end{array}$ & $\begin{array}{l}\text { Permit to Construct a Well } \\
(\mathrm{MW}-10)\end{array}$ & $\begin{array}{l}\text { Colorado } \\
\text { Department of } \\
\text { Natural Resources }\end{array}$ & inactive \\
\hline Permit & 214962 & NREL/DOE & $\begin{array}{c}\text { GW } \\
\text { Monitoring } \\
\text { Well }\end{array}$ & $\begin{array}{l}\text { Permit to Construct a Well } \\
(\mathrm{MW}-09)\end{array}$ & $\begin{array}{l}\text { Colorado } \\
\text { Department of } \\
\text { Natural Resources }\end{array}$ & inactive \\
\hline $\begin{array}{l}\text { Notification } \\
\text { and } \\
\text { Registration }\end{array}$ & CO4890000017 & DOE & $\begin{array}{l}\text { HAZARDOU } \\
\text { S WASTE }\end{array}$ & $\begin{array}{l}\text { Notification of Regulated } \\
\text { Waste Activity }\end{array}$ & $\begin{array}{l}\text { Colorado Dept. of } \\
\text { Public Health and } \\
\text { Environment }\end{array}$ & in effect \\
\hline $\begin{array}{l}\text { Notification } \\
\text { and } \\
\text { Registration }\end{array}$ & CO3890090076 & DOE & $\begin{array}{l}\text { HAZARDOU } \\
\text { S WASTE }\end{array}$ & $\begin{array}{l}\text { Notification of Regulated } \\
\text { Waste Activity }\end{array}$ & $\begin{array}{l}\text { Colorado Dept. of } \\
\text { Public Health and } \\
\text { Environment }\end{array}$ & in effect \\
\hline $\begin{array}{l}\text { Notification } \\
\text { and } \\
\text { Registration }\end{array}$ & COD980805162 & DOE & $\begin{array}{l}\text { HAZARDOU } \\
\text { S WASTE }\end{array}$ & $\begin{array}{l}\text { Notification of Regulated } \\
\text { Waste Activity }\end{array}$ & $\begin{array}{l}\text { Colorado Dept. of } \\
\text { Public Health and } \\
\text { Environment }\end{array}$ & in effect \\
\hline $\begin{array}{l}\text { Notification } \\
\text { and } \\
\text { Registration }\end{array}$ & COD983802448 & DOE & $\begin{array}{l}\text { HAZARDOU } \\
\text { S WASTE }\end{array}$ & $\begin{array}{l}\text { Notification of Regulated } \\
\text { Waste Activity }\end{array}$ & $\begin{array}{l}\text { Colorado Dept. of } \\
\text { Public Health and } \\
\text { Environment }\end{array}$ & in effect \\
\hline $\begin{array}{l}\text { Notification } \\
\text { and } \\
\text { Registration }\end{array}$ & COR000207563 & DOE & $\begin{array}{l}\text { HAZARDOU } \\
\text { S WASTE }\end{array}$ & $\begin{array}{l}\text { Notification of Regulated } \\
\text { Waste Activity }\end{array}$ & $\begin{array}{l}\text { Colorado Dept. of } \\
\text { Public Health and } \\
\text { Environment }\end{array}$ & in effect \\
\hline Permit & 2213 & NREL & HazMat & $\begin{array}{l}\text { Hazardous material storage } \\
\text { and use permit }\end{array}$ & $\begin{array}{l}\text { West Metro Fire } \\
\text { Rescue }\end{array}$ & Active \\
\hline Permit & 2214 & NREL & HazMat & $\begin{array}{l}\text { Hazardous material storage } \\
\text { and use permit }\end{array}$ & $\begin{array}{l}\text { West Metro Fire } \\
\text { Rescue }\end{array}$ & Active \\
\hline Permit & 2209 & NREL & HazMat & $\begin{array}{l}\text { Hazardous material storage } \\
\text { and use permit }\end{array}$ & $\begin{array}{l}\text { West Metro Fire } \\
\text { Rescue }\end{array}$ & Active \\
\hline
\end{tabular}




\begin{tabular}{|c|c|c|c|c|c|c|}
\hline Category & $\begin{array}{l}\text { Permit or } \\
\text { Registration } \\
\text { Number }\end{array}$ & $\begin{array}{c}\text { Permit or } \\
\text { Reg. Holder }\end{array}$ & Permit Type & Permit Description & Issuing Agency & Status \\
\hline Permit & 2211 & NREL & HazMat & $\begin{array}{l}\text { Hazardous material storage } \\
\text { and use permit }\end{array}$ & $\begin{array}{l}\text { West Metro Fire } \\
\text { Rescue }\end{array}$ & Active \\
\hline Permit & 2215 & NREL & HazMat & $\begin{array}{l}\text { Hazardous material storage } \\
\text { and use permit }\end{array}$ & $\begin{array}{l}\text { West Metro Fire } \\
\text { Rescue }\end{array}$ & Active \\
\hline Permit & 2212 & NREL & HazMat & $\begin{array}{l}\text { Hazardous material storage } \\
\text { and use permit }\end{array}$ & $\begin{array}{l}\text { West Metro Fire } \\
\text { Rescue }\end{array}$ & Active \\
\hline Permit & 2210 & NREL & HazMat & $\begin{array}{l}\text { Hazardous material storage } \\
\text { and use permit }\end{array}$ & $\begin{array}{l}\text { West Metro Fire } \\
\text { Rescue }\end{array}$ & Active \\
\hline $\begin{array}{l}\text { Notification } \\
\text { and } \\
\text { Registration }\end{array}$ & 93000378 & $\mathrm{DOE}$ & $\begin{array}{c}\text { Historic } \\
\text { Registration }\end{array}$ & $\begin{array}{l}\text { National Register of Historic } \\
\text { Places }\end{array}$ & $\begin{array}{l}\text { National Park } \\
\text { Service }\end{array}$ & No expiration \\
\hline $\begin{array}{l}\text { Notification } \\
\text { and } \\
\text { Registration }\end{array}$ & 93000379 & $\mathrm{DOE}$ & $\begin{array}{c}\text { Historic } \\
\text { Registration }\end{array}$ & $\begin{array}{l}\text { National Register of Historic } \\
\text { Places }\end{array}$ & $\begin{array}{l}\text { National Park } \\
\text { Service }\end{array}$ & No expiration \\
\hline Permit & TBD & NREL & $\begin{array}{l}\text { Migratory } \\
\text { Birds }\end{array}$ & $\begin{array}{l}\text { special purpose permit for } \\
\text { salvage (removal and } \\
\text { disposition) of birds found } \\
\text { dead at NREL }\end{array}$ & & in progress \\
\hline $\begin{array}{l}\text { Notification } \\
\text { and } \\
\text { Registration }\end{array}$ & 85936 & NREL & Registration & $\begin{array}{l}\text { X-Ray Machine Certification } \\
\text { Report }\end{array}$ & $\begin{array}{l}\text { Colorado Dept. of } \\
\text { Public Health and } \\
\text { Environment }\end{array}$ & Active \\
\hline $\begin{array}{l}\text { Notification } \\
\text { and } \\
\text { Registration }\end{array}$ & 85938 & NREL & Registration & $\begin{array}{l}\text { X-Ray Machine Certification } \\
\text { Report }\end{array}$ & $\begin{array}{l}\text { Colorado Dept. of } \\
\text { Public Health and } \\
\text { Environment }\end{array}$ & Active \\
\hline $\begin{array}{l}\text { Notification } \\
\text { and } \\
\text { Registration }\end{array}$ & 92056 & NREL & Registration & $\begin{array}{l}\text { X-Ray Machine Certification } \\
\text { Report }\end{array}$ & $\begin{array}{l}\text { Colorado Dept. of } \\
\text { Public Health and } \\
\text { Environment }\end{array}$ & Active \\
\hline $\begin{array}{l}\text { Notification } \\
\text { and } \\
\text { Registration }\end{array}$ & 85937 & NREL & Registration & $\begin{array}{l}\text { X-Ray Machine Certification } \\
\text { Report }\end{array}$ & $\begin{array}{l}\text { Colorado Dept. of } \\
\text { Public Health and } \\
\text { Environment }\end{array}$ & Active \\
\hline
\end{tabular}




\begin{tabular}{|c|c|c|c|c|c|c|}
\hline Category & $\begin{array}{l}\text { Permit or } \\
\text { Registration } \\
\text { Number }\end{array}$ & $\begin{array}{c}\text { Permit or } \\
\text { Reg. Holder }\end{array}$ & Permit Type & Permit Description & Issuing Agency & Status \\
\hline Permit & COR10CY5F & $\begin{array}{l}\text { Alliance for } \\
\text { Sustainable } \\
\text { Energy, LLC }\end{array}$ & Storm Water & $\begin{array}{l}\text { Construction General Permit } \\
\text { (Stormwater) COR10000F }\end{array}$ & $\begin{array}{l}\text { U. S. } \\
\text { Environmental } \\
\text { Protection Agency }\end{array}$ & Active \\
\hline Permit & COR10CY6F & DOE & Storm Water & $\begin{array}{l}\text { Construction General Permit } \\
\text { (Stormwater) COR10000F }\end{array}$ & $\begin{array}{l}\text { U. S. } \\
\text { Environmental } \\
\text { Protection Agency }\end{array}$ & Active \\
\hline Permit & COR10D88F & $\begin{array}{l}\text { Alliance for } \\
\text { Sustainable } \\
\text { Energy, LLC }\end{array}$ & Storm Water & $\begin{array}{l}\text { Construction General Permit } \\
\text { (Stormwater) COR10000F }\end{array}$ & $\begin{array}{l}\text { U. S. } \\
\text { Environmental } \\
\text { Protection Agency }\end{array}$ & Active \\
\hline Permit & COR10DH3F & $\begin{array}{l}\text { Alliance for } \\
\text { Sustainable } \\
\text { Energy, LLC }\end{array}$ & Storm Water & $\begin{array}{l}\text { Construction General Permit } \\
\text { (Stormwater) COR10000F }\end{array}$ & $\begin{array}{l}\text { U. S. } \\
\text { Environmental } \\
\text { Protection Agency }\end{array}$ & Active \\
\hline Permit & COR10DH4F & DOE & Storm Water & $\begin{array}{l}\text { Construction General Permit } \\
\text { (Stormwater) COR10000F }\end{array}$ & $\begin{array}{l}\text { U. S. } \\
\text { Environmental } \\
\text { Protection Agency }\end{array}$ & Active \\
\hline Permit & COR10DI9F & $\begin{array}{c}\text { Haselden } \\
\text { Construction }\end{array}$ & Storm Water & $\begin{array}{l}\text { Construction General Permit } \\
\text { (Stormwater) COR10000F }\end{array}$ & $\begin{array}{l}\text { U. S. } \\
\text { Environmental } \\
\text { Protection Agency }\end{array}$ & Active \\
\hline Permit & COR10E21F & $\begin{array}{l}\text { Alliance for } \\
\text { Sustainable } \\
\text { Energy, LLC }\end{array}$ & Storm Water & $\begin{array}{l}\text { Construction General Permit } \\
\text { (Stormwater) COR10000F }\end{array}$ & $\begin{array}{l}\text { U. S. } \\
\text { Environmental } \\
\text { Protection Agency }\end{array}$ & Active \\
\hline Permit & COR10E20F & DOE & Storm Water & $\begin{array}{l}\text { Construction General Permit } \\
\text { (Stormwater) COR } 10000 \mathrm{~F}\end{array}$ & $\begin{array}{l}\text { U. S. } \\
\text { Environmental } \\
\text { Protection Agency }\end{array}$ & Active \\
\hline Permit & COR10E23F & $\begin{array}{c}\text { Haselden } \\
\text { Construction }\end{array}$ & Storm Water & $\begin{array}{l}\text { Construction General Permit } \\
\text { (Stormwater) COR } 10000 \mathrm{~F}\end{array}$ & $\begin{array}{l}\text { U. S. } \\
\text { Environmental } \\
\text { Protection Agency }\end{array}$ & Active \\
\hline Permit & COR10DA6F & $\begin{array}{c}\text { Alliance for } \\
\text { Sustainable } \\
\text { Energy, LLC }\end{array}$ & Storm Water & $\begin{array}{l}\text { Construction General Permit } \\
\text { (Stormwater) COR } 10000 \mathrm{~F}\end{array}$ & $\begin{array}{l}\text { U. S. } \\
\text { Environmental } \\
\text { Protection Agency }\end{array}$ & Active \\
\hline
\end{tabular}




\begin{tabular}{|c|c|c|c|c|c|c|}
\hline Category & $\begin{array}{l}\text { Permit or } \\
\text { Registration } \\
\text { Number }\end{array}$ & $\begin{array}{c}\text { Permit or } \\
\text { Reg. Holder }\end{array}$ & Permit Type & Permit Description & Issuing Agency & Status \\
\hline Permit & COR10DA5F & DOE & Storm Water & $\begin{array}{l}\text { Construction General Permit } \\
\text { (Stormwater) COR10000F }\end{array}$ & $\begin{array}{l}\text { U. S. } \\
\text { Environmental } \\
\text { Protection Agency }\end{array}$ & Active \\
\hline Permit & COR10DA9F & $\begin{array}{l}\text { Mortenson } \\
\text { Construction }\end{array}$ & Storm Water & $\begin{array}{l}\text { Construction General Permit } \\
\text { (Stormwater) COR10000F }\end{array}$ & $\begin{array}{l}\text { U. S. } \\
\text { Environmental } \\
\text { Protection Agency }\end{array}$ & Active \\
\hline Permit & COR10E08F & $\begin{array}{l}\text { Alliance for } \\
\text { Sustainable } \\
\text { Energy, LLC }\end{array}$ & Storm Water & $\begin{array}{l}\text { Construction General Permit } \\
\text { (Stormwater) COR10000F }\end{array}$ & $\begin{array}{l}\text { U. S. } \\
\text { Environmental } \\
\text { Protection Agency }\end{array}$ & Active \\
\hline Permit & COR10E09F & DOE & Storm Water & $\begin{array}{l}\text { Construction General Permit } \\
\text { (Stormwater) COR10000F }\end{array}$ & $\begin{array}{l}\text { U. S. } \\
\text { Environmental } \\
\text { Protection Agency }\end{array}$ & Active \\
\hline Permit & COR10E16F & $\begin{array}{c}\mathrm{CG} \\
\text { Construction }\end{array}$ & Storm Water & $\begin{array}{l}\text { Construction General Permit } \\
\text { (Stormwater) COR10000F }\end{array}$ & $\begin{array}{l}\text { U. S. } \\
\text { Environmental } \\
\text { Protection Agency }\end{array}$ & Active \\
\hline Permit & COR10E12F & $\begin{array}{l}\text { Alliance for } \\
\text { Sustainable } \\
\text { Energy, LLC }\end{array}$ & Storm Water & $\begin{array}{l}\text { Construction General Permit } \\
\text { (Stormwater) COR10000F }\end{array}$ & $\begin{array}{l}\text { U. S. } \\
\text { Environmental } \\
\text { Protection Agency }\end{array}$ & Active \\
\hline Permit & COR10E10F & DOE & Storm Water & $\begin{array}{l}\text { Construction General Permit } \\
\text { (Stormwater) COR10000F }\end{array}$ & $\begin{array}{l}\text { U. S. } \\
\text { Environmental } \\
\text { Protection Agency }\end{array}$ & Active \\
\hline Permit & COR10E13F & $\begin{array}{c}\mathrm{CG} \\
\text { Construction }\end{array}$ & Storm Water & $\begin{array}{l}\text { Construction General Permit } \\
\text { (Stormwater) COR } 10000 \mathrm{~F}\end{array}$ & $\begin{array}{l}\text { U. S. } \\
\text { Environmental } \\
\text { Protection Agency }\end{array}$ & Active \\
\hline Permit & COR10DD2F & $\begin{array}{c}\text { Alliance for } \\
\text { Sustainable } \\
\text { Energy, LLC }\end{array}$ & Storm Water & $\begin{array}{l}\text { Construction General Permit } \\
\text { (Stormwater) COR } 10000 \mathrm{~F}\end{array}$ & $\begin{array}{l}\text { U. S. } \\
\text { Environmental } \\
\text { Protection Agency }\end{array}$ & Active \\
\hline Permit & COR10DD1F & $\mathrm{DOE}$ & Storm Water & $\begin{array}{l}\text { Construction General Permit } \\
\text { (Stormwater) COR } 10000 \mathrm{~F}\end{array}$ & $\begin{array}{l}\text { U. S. } \\
\text { Environmental } \\
\text { Protection Agency }\end{array}$ & Active \\
\hline
\end{tabular}




\begin{tabular}{|c|c|c|c|c|c|c|}
\hline Category & $\begin{array}{c}\text { Permit or } \\
\text { Registration } \\
\text { Number }\end{array}$ & $\begin{array}{c}\text { Permit or } \\
\text { Reg. Holder }\end{array}$ & Permit Type & Permit Description & Issuing Agency & Status \\
\hline Permit & COR10DD4F & Sun Edison & Storm Water & $\begin{array}{l}\text { Construction General Permit } \\
\text { (Stormwater) COR10000F }\end{array}$ & $\begin{array}{l}\text { U. S. } \\
\text { Environmental } \\
\text { Protection Agency }\end{array}$ & Active \\
\hline Permit & COR10DB4F & $\begin{array}{l}\text { Alliance for } \\
\text { Sustainable } \\
\text { Energy, LLC }\end{array}$ & Storm Water & $\begin{array}{l}\text { Construction General Permit } \\
\text { (Stormwater) COR10000F }\end{array}$ & $\begin{array}{l}\text { U. S. } \\
\text { Environmental } \\
\text { Protection Agency }\end{array}$ & Active \\
\hline Permit & COR10E06F & $\begin{array}{c}\text { Alliance for } \\
\text { Sustainable } \\
\text { Energy, LLC }\end{array}$ & Storm Water & $\begin{array}{l}\text { Construction General Permit } \\
\text { (Stormwater) COR10000F }\end{array}$ & $\begin{array}{l}\text { U. S. } \\
\text { Environmental } \\
\text { Protection Agency }\end{array}$ & Active \\
\hline Permit & COR10E07F & DOE & Storm Water & $\begin{array}{l}\text { Construction General Permit } \\
\text { (Stormwater) COR10000F }\end{array}$ & $\begin{array}{l}\text { U. S. } \\
\text { Environmental } \\
\text { Protection Agency }\end{array}$ & Active \\
\hline Permit & COR10E15F & $\begin{array}{c}\mathrm{CG} \\
\text { Construction }\end{array}$ & Storm Water & $\begin{array}{l}\text { Construction General Permit } \\
\text { (Stormwater) COR10000F }\end{array}$ & $\begin{array}{l}\text { U. S. } \\
\text { Environmental } \\
\text { Protection Agency }\end{array}$ & Active \\
\hline Permit & COR10CT8F & DOE & Storm Water & $\begin{array}{l}\text { Construction General Permit } \\
\text { (Stormwater) COR10000F }\end{array}$ & $\begin{array}{l}\text { U. S. } \\
\text { Environmental } \\
\text { Protection Agency }\end{array}$ & Active \\
\hline Permit & COR10CiOF & DOE & Storm Water & $\begin{array}{l}\text { Construction General Permit } \\
\text { (Stormwater) COR10000F }\end{array}$ & $\begin{array}{l}\text { U. S. } \\
\text { Environmental } \\
\text { Protection Agency }\end{array}$ & Active \\
\hline $\begin{array}{l}\text { Notification } \\
\text { and } \\
\text { Registration }\end{array}$ & 062008550086QS & MRI & Transporation & $\begin{array}{l}\text { Hazardous Material } \\
\text { Transportation }\end{array}$ & $\begin{array}{l}\text { U. S. Department of } \\
\text { Transportation }\end{array}$ & Active \\
\hline $\begin{array}{l}\text { Notification } \\
\text { and } \\
\text { Registration }\end{array}$ & & NREL & Waiver & $\begin{array}{l}\text { Certificate of Waiver or } \\
\text { Authorization }\end{array}$ & $\begin{array}{l}\text { Department of } \\
\text { Transportation }\end{array}$ & Expired \\
\hline $\begin{array}{l}\text { Notification } \\
\text { and } \\
\text { Registration }\end{array}$ & $\begin{array}{c}\text { Army Corps File\# } \\
\text { NWO-2009- } \\
\text { 1014-DEN } \\
\end{array}$ & $\begin{array}{c}\text { Alliance for } \\
\text { Sustainable } \\
\text { Energy, LLC }\end{array}$ & Wetlands & Jurisdictional Determination & $\begin{array}{l}\text { U. S. Army Corps } \\
\text { of Engineers }\end{array}$ & Active \\
\hline
\end{tabular}




\begin{tabular}{|c|c|c|c|c|c|c|}
\hline Category & $\begin{array}{c}\text { Permit or } \\
\text { Registration } \\
\text { Number }\end{array}$ & $\begin{array}{c}\text { Permit or } \\
\text { Reg. Holder }\end{array}$ & Permit Type & Permit Description & Issuing Agency & Status \\
\hline $\begin{array}{l}\text { Notification } \\
\text { and } \\
\text { Registration }\end{array}$ & $\begin{array}{c}\text { Army Corps File\# } \\
\text { NWO-2009- } \\
\text { 1014-DEN }\end{array}$ & $\begin{array}{c}\text { Alliance for } \\
\text { Sustainable } \\
\text { Energy, LLC }\end{array}$ & Wetlands & Jurisdictional Determination & $\begin{array}{l}\text { U. S. Army Corps } \\
\text { of Engineers }\end{array}$ & Active \\
\hline Permit & 09-106687GP & DOE & $\begin{array}{c}\text { Earth } \\
\text { Disturbance }\end{array}$ & Grading permit & Jefferson County & Expired \\
\hline Permit & 10-106216GB & DOE & $\begin{array}{c}\text { Earth } \\
\text { Disturbance }\end{array}$ & Grading permit & Jefferson County & active \\
\hline Fee & $\begin{array}{c}\text { PSWID } \\
\text { CO0230860 }\end{array}$ & USDOE/NREL & NA & $\begin{array}{l}\text { Annual safe drinking water } \\
\text { program fee }\end{array}$ & $\begin{array}{l}\text { Colorado Dept. of } \\
\text { Public Health and } \\
\text { Environment }\end{array}$ & NA \\
\hline Fee & CO3890090076 & & NA & $\begin{array}{l}\text { HazWaste Annual } \\
\text { Generator/Commission }\end{array}$ & $\begin{array}{l}\text { Colorado Dept. of } \\
\text { Public Health and } \\
\text { Environment }\end{array}$ & $\mathrm{NA}$ \\
\hline Fee & CO4890000017 & & NA & $\begin{array}{l}\text { HazWaste Annual } \\
\text { Generator/Commission }\end{array}$ & $\begin{array}{l}\text { Colorado Dept. of } \\
\text { Public Health and } \\
\text { Environment }\end{array}$ & NA \\
\hline $\begin{array}{l}\text { Notification } \\
\text { and } \\
\text { Registration }\end{array}$ & $\begin{array}{c}\text { PSWID } \\
\text { CO0230860 }\end{array}$ & $\mathrm{DOE}$ & NA & $\begin{array}{l}\text { Operator in Responsible } \\
\text { Charge }\end{array}$ & $\begin{array}{l}\text { Colorado Dept. of } \\
\text { Public Health and } \\
\text { Environment }\end{array}$ & active \\
\hline
\end{tabular}




\subsection{Appendix B: Wildlife Species Observed at NREL's STM Site}

The following is a list of common and scientific names of wildlife species observed during wildlife surveys at NREL's South Table Mountain site in Golden, Colorado.

Table 7. Wildlife Species Observed at NREL's STM Site

\begin{tabular}{|c|c|}
\hline Common Name & Scientific Name \\
\hline \multicolumn{2}{|l|}{ Reptiles } \\
\hline Bull snake $^{1}$ & Pituophis catenifer \\
\hline Plains garter snake & Thamnophis radix \\
\hline Six-lined racerunner & Cnemidophorus sexlineatus \\
\hline Tiger salamander & Ambystoma tigrinum \\
\hline Western rattlesnake & Crotalus viridus \\
\hline \multicolumn{2}{|l|}{ Birds } \\
\hline American crow & Corvus brachyrhynchos \\
\hline American kestrel & Falco sparverius \\
\hline American robin & Turdus migratorius \\
\hline American tree sparrow & Spizella arborea \\
\hline Barn swallow & Hirundo rustica \\
\hline Black-billed magpie & Pica pica \\
\hline Black-capped chickadee & Poecile atricapilla \\
\hline Black-crowned night heron & Nycticorax nycticorax \\
\hline Blue jay & Cyanocitta cristata \\
\hline Brewer's blackbird & Euphagus cyanocephalus \\
\hline Brown headed cowbird & Molothrus ater \\
\hline Bullock's oriole & Icterus bullockii \\
\hline California gull & Larus californicus \\
\hline Canada goose & Branta canadensis \\
\hline Cedar Waxwing & Bombycilla cedrorum \\
\hline Common nighthawk & Chordeiles minor \\
\hline Common raven & Corvus corax \\
\hline Common snipe & Gallinago gallinago \\
\hline Cooper's hawk & Accipiter cooperii \\
\hline Dark-eyed junco & Junco hyemalis \\
\hline Downy woodpecker & Picoides pubescens \\
\hline European starling & Sturnus vulgaris \\
\hline Flycatcher & Empidonax sp. \\
\hline Golden eagle & Aquila chrysaetos \\
\hline Great blue heron & Ardea herodias \\
\hline Horned lark & Eremophila alpestris \\
\hline House finch & Carpodacus mexicanus \\
\hline House sparrow & Passer domesticus \\
\hline Killdeer & Charadrius vociferous \\
\hline Lark bunting & Calamospiza melanocorys \\
\hline Loggerhead shrike & Lanius ludovicianus \\
\hline MacGillivray's warbler & Oporornis tolmiei \\
\hline Mallard & Anas platyrhynchos \\
\hline Mountain bluebird & Sialia currucoides \\
\hline Mourning dove & Zenaida macroura \\
\hline Northern flicker & Colaptes auratus \\
\hline Northern harrier & Circus cyaneus \\
\hline Osprey & Pandion haliaetus \\
\hline
\end{tabular}




\begin{tabular}{|l|l|}
\hline \multicolumn{1}{|c|}{ Common Name } & \multicolumn{1}{|c|}{ Scientific Name } \\
\hline Prairie falcon & Falco mexicanus \\
\hline Red-breasted nuthatch & Sitta canadensis \\
\hline Red-tailed hawk & Buteo jamaicensis \\
\hline Red-winged blackbird & Agelaius phoeniceus \\
\hline Rock dove & Columba livia \\
\hline Rock wren & Salpinctes obsoletus \\
\hline Say's phoebe & Sayornis saya \\
\hline Sharp-shinned hawk & Accipiter striatus \\
\hline Spotted towhee & Pipilo maculates \\
\hline Swainson's hawk & Buteo swainsoni \\
\hline Tree swallow & Tachycineta bicolor \\
\hline Turkey vulture & Cathartes aura \\
\hline Vesper sparrow & Pooecetes gramineus \\
\hline Western kingbird & Tyrannus verticalis \\
\hline Western meadowlark & Sturnella neglecta \\
\hline Western scrub jay & Aphelocoma californica \\
\hline White-crowned sparrow & Zonotrichia leucophrys \\
\hline Mammals & \multicolumn{2}{|l|}{} \\
\hline Black-tailed jackrabbit & \\
\hline Bushy-tailed woodrat & \\
\hline Coyote & Lepus californicus \\
\hline Deer mouse & Neotoma cinerea \\
\hline Fox squirrel & Canis latrans \\
\hline Long-tailed weasel & Peromyscus maniculatus \\
\hline Mexican woodrat & Sciurus niger \\
\hline Mountain cottontail & Mustela frenata \\
\hline Mule deer & Neotoma mexicana \\
\hline Prairie vole & Sylvilagus nuttalli \\
\hline Raccoon & Odocoileus hemionus \\
\hline Red fox & Microtus ochrogaster \\
\hline Western harvest mouse & Procyon lotor \\
\hline White-tailed jackrabbit & Vulpes vulpes \\
\hline Yellow-bellied marmot & Reithrodontomys megalotis \\
\hline & Lepus townsendii \\
\hline & Marmota flaviventris \\
\hline
\end{tabular}

